\title{
INFORMAÇÃO, CAPITAL SOCIAL E MERCADO DE CRÉDITO RURAL
}

\author{
Roberto Arruda de Souza Lima
}

\author{
Tese apresentada à Escola Superior de Agricultura \\ "Luiz de Queiroz", Universidade de São Paulo, para \\ obtenção do título de Doutor em Economia, Área de \\ Concentração: Economia Aplicada.
}

P I R A C I C A B A

Estado de São Paulo - Brasil

Março - 2003 


\title{
INFORMAÇÃO, CAPITAL SOCIAL E MERCADO DE CRÉDITO RURAL
}

\section{Roberto Arruda de Souza Lima}

\author{
Engenheiro Agrônomo
}

\section{Orientador: Prof. Dr. RICARDO SHIROTA}

\author{
Tese apresentada à Escola Superior de Agricultura \\ "Luiz de Queiroz", Universidade de São Paulo, para \\ obtenção do título de Doutor em Economia, Área de \\ Concentração: Economia Aplicada.
}

P I R A C I C A B A

Estado de São Paulo - Brasil

Março - 2003 
Dados Internacionais de Catalogação na Publicação (CIP)

DIVISÃO DE BIBLIOTECA E DOCUMENTAÇÃO - ESALQ/ USP

Lima, Roberto Arruda de Souza

Informação, capital social e mercado de crédito rural / Roberto Arruda de

Souza Lima. - - Piracicaba, 2003.

236 p. : il.

Tese (doutorado) - Escola Superior de Agricultura Luiz de Queiroz, 2003.

Bibliografia.

1. Capital social 2. Crédito rural 3. Financiamento agrícola 4. Mercado financeiro I. Título

CDD 332.71

'Permitida a cópia total ou parcial deste documento, desde que citada a fonte - 0 autor" 


\section{DEDICO}

Aos meus avós,

Oscar Leite Arruda (in memoriam) e Arthur Pereira de Souza Lima (in memoriam) 


\section{AGRADECIMENTOS}

Poderia realizar os agradecimentos relembrando o tempo investido dentro e fora das salas de aulas ao longo do programa de doutorado. Mas, nas palavras de Apollinaire, "quando falo do tempo é porque ele já não existe", e esta etapa de minha vida estará sempre presente. Assim, nestas páginas iniciais não falarei "do tempo" mas das marcas indeléveis desta fase, sob uma ótica menos acadêmica, mais vivencial e pessoal, comentando os conceitos centrais deste trabalho: informação, capital social e crédito.

Informação.

"A ESALQ existe para ensinar; cumprindo missão vitoriosa"1. Esta missão só é possível face ao corpo docente do qual destaco, e agradeço, os professores Alexandre Lahóz Mendonça de Barros, Carlos José Caetano Bacha, Fernando Curi Peres, Geraldo Sant'Ana de Camargo Barros, Joaquim Bento de Souza Ferreira Filho, Márcia Azanha Ferraz Dias de Moraes e Pedro Carvalho de Mello. E a eficiência na transmissão das informações é resultado do apoio de funcionários de excelência como Maielli, Pedro, Ligiana e Álvaro. Muito obrigado pelo privilégio de poder contar com esta equipe.

\section{Capital social.}

A interação (e cooperação) com amigos e colegas, como Alivínio, Arlélio, Conchas, Daniel, Henrique, Janete, Perina, Rogério, Tiziu e Vitor, entre muitos, foi fundamental para a produção deste trabalho e para meu enriquecimento.

\footnotetext{
${ }^{1}$ Versos do Hino da ESALQ, de autoria do Prof. Zilmar Ziller Marcos.
} 
Crédito.

A confiança resultante da informação e do capital social. Aos Professores Evaristo Marzabal Neves, Paulo Fernando Cidade de Araujo e Ada Pellegrini Grinover, agradeço principalmente por acreditarem no meu potencial, pela amizade e pelos exemplos profissionais. Agradeço, também, a CAPES pelo apoio financeiro ao longo de quase todo programa.

Ao meu orientador e amigo, Ricardo Shirota, minha gratidão ultrapassa os sólidos ensinamentos de suas aulas e discussões, a firmeza de sua orientação, o incentivo e apoio fraternal sempre presente (inclusive de Eliza, Camila, Ricardinho, e Alexandre) .

Meus pais, Victor e Nilza. Expressar em palavras a infinita gratidão e admiração que tenho por eles está acima de minha capacidade. Multiplico os agradecimentos que diariamente faço por tê-los sempre ao meu lado. São minha referência e porto seguro.

À Cristiane e às minhas filhas, Luiza e Helena, mais do que o agradecimento pela luz e calor que me trazem, o perdão pelas horas de convívio que foram substituídas por horas de trabalho.

"E tu, pecador, que vagueias,

Que fazes ao teu Criador?

Não achas momento em que cantes

Um hino de glória ao Senhor?"2

Agradeço e louvo a Deus pelas informações, pelos relacionamentos sociais, pelo crédito e confiança que recebi e pelo trabalho realizado.

\footnotetext{
${ }^{2}$ Um Hino ao Senhor - hino cristão de autoria desconhecida.
} 


\section{SUMÁRIO}

Página

LISTA DE FIGURAS ..................................................................... viii

LISTA DE TABELAS .................................................................... xii

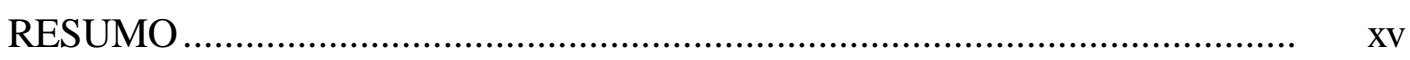

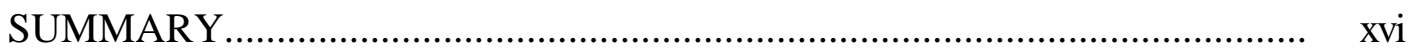

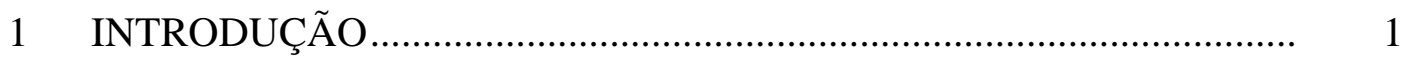

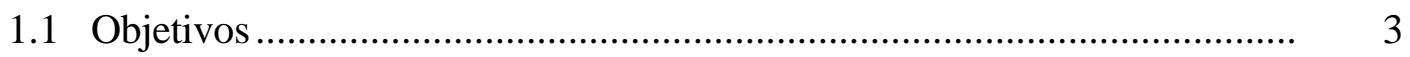

1.2 Organização do trabalho .................................................................. 4

2 EVOLUÇÃO E SITUAÇÃO ATUAL DO CRÉDITO RURAL NO BRASIL ............................................................................ 6

2.1 Evolução do crédito rural no Brasil .................................................... 6

2.2 Políticas macroeconômicas e a política de crédito rural no Brasil ............ 18

2.3 Situação atual do crédito rural no Brasil................................................. 34

3 A IMPORTÂNCIA DAS INSTITUIÇÕES FINANCEIRAS

PARA O FINANCIAMENTO RURAL ................................................ 40

3.1 Papel do sistema financeiro ........................................................ 40

3.2 Custos da intermediação financeira ..................................................... $\quad 50$

3.3 Inadimplência e o acesso ao crédito bancário ......................................... 62

4 DETERMINAÇÃO DA ESTRUTURA DE MERCADO ....................... 67

5 INFORMAÇÃO E CAPITAL SOCIAL ............................................... 74

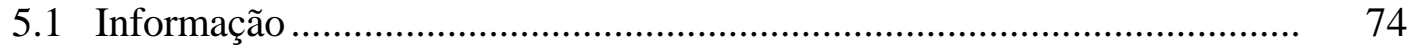

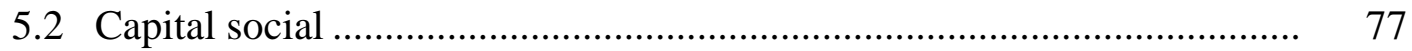

5.3 Mensuração do capital social............................................................ 86 
5.4 Capital social e acesso ao crédito ............................................................. 94

6 CONFIABILIDADE E A OFERTA DE CRÉDITO RURAL ................... 102

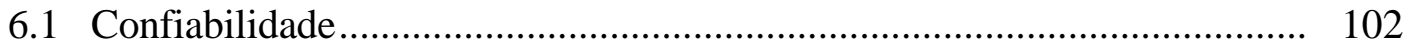

6.2 Volume de crédito rural...................................................................... 104

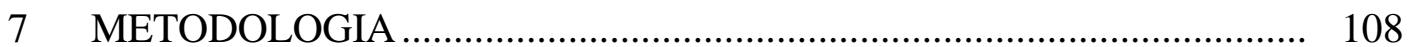

7.1 Hipótese referente ao volume negociado de crédito rural .......................... 108

7.2 Efeito do capital social..................................................................... 112

7.3 Modelo econométrico ................................................................... 114

7.4 Variáveis utilizadas no modelo.............................................................. 119

7.5 Tratamento dos dados ..................................................................... 124

8 RESULTADOS ....................................................................... 128

8.1 Características gerais da população amostrada.......................................... 128

8.2 Análise de regressão ......................................................................... 137

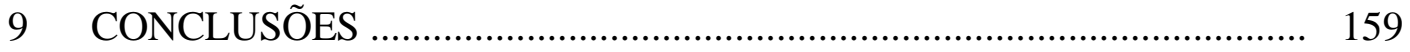

REFERÊNCIAS BIBLIOGRÁFICAS ....................................................... 163

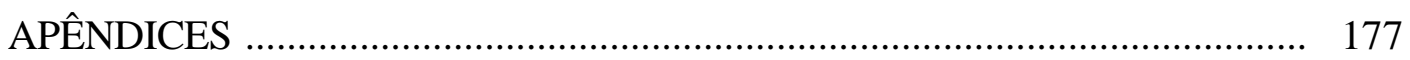




\section{LISTA DE FIGURAS}

Página

1 Brasil: estimativa da evolução das exportações de diferentes produtos entre 1500 e 1820 , em milhões de Libras.

2 Brasil: número de contratos e valor dos financiamentos (em $\mathrm{Cr} \$$ milhões de 1978) destinados à agropecuária nos anos de 1938, 1948, 1958, 1968 e 1978.

3 Brasil: evolução do volume anual de recursos destinados ao crédito rural, 1969 a 2000, em bilhões de Reais de 2000.

4 Brasil: evolução do volume mensal de crédito rural concedido, por tipo de instituição financeira, janeiro de 1996 a dezembro de 2000, em milhões de Reais de dezembro de 2000.

5 Brasil: variação do índice sazonal do volume de crédito rural, janeiro de 1996 a dezembro de 2000.

6 Brasil: evolução do valor médio mensal dos contratos de crédito rural, por tipo de instituição financeira, janeiro de 1996 a dezembro de 2000 (em de Reais de dezembro de 2000).

7 Brasil: evolução da participação percentual dos setores agricultura, indústria e serviços no $\mathrm{PIB}_{\mathrm{CF}}, 1950$ a 2000.

8 Brasil: variação anual do IGP/DI no período de 1944 a 1964, em percentual.

9 Brasil: participação percentual de diferentes instituições financeiras no volume anual de crédito rural concedido, de 1969 a 2000 . 
10 Brasil: evolução da taxa de juros real em operações de crédito rural para custeio, 1970 a 1995, em \% a.a. .......................................... 26

11 Brasil: evolução da participação no saldo médio do crédito rural, por tipo de agente financeiro, no período de 1971 a 1981 ....................... 29

12 Brasil: evolução da balança comercial, 1950 a 2001, em bilhões de dólares.

13 Brasil: evolução da produção de grãos, em milhões de toneladas, e do volume de crédito rural e do PIB-Agricultura, em bilhões de dólares, período de 1965 a 1980.

14 Brasil: evolução da participação relativa das principais fontes de recursos nos financiamentos concedidos a produtores e cooperativas, em percentual, de 1985 a 1999.

15 Fluxo de capitais e o sistema financeiro.

16 Modelo neoclássico de equilíbrio competitivo entre oferta e demanda de crédito.

17 Oferta e demanda de crédito.

18 Impacto da redução dos custos de transação no racionamento de crédito.

19 Existência de taxa de juros que maximiza o retorno esperado pelo banco.

20 Racionamento de crédito com intermediação financeira.

21 Custo Médio (CMe), Custo Marginal (CMa), e sua relação com economia de escala $[S(y)]$ para o caso de um único produto.

22 Superfície de custo hipotética para o caso de dois produtos.

23 Exemplos de mudanças na escala e na composição de produtos no caso de dois produtos.

24 Conjunto de estoques de capitais que condicionam o crescimento das economias.

25 Estrutura com três pessoas: capital humano nos nós e capital social nas relações 
26 Estrutura social (a) com abertura e (b) com fechamento.

27 Relação hipotética ente taxa de juros, confiabilidade e o volume de crédito ofertado.

28 Curva de oferta de crédito. 105

29 Curva de demanda de crédito. 106

30 Mercado de crédito rural 107

31 Mercado de crédito rural com elevação da confiabilidade.

32 Modelo RAROC: Distribuição hipotética de perdas e taxa de insolvência objetivada.

33 Municípios eliminados da amostra por não apresentar em estatísticas completas na base de dados do SEADE.

34 Estado de São Paulo: distribuição geográfica e histograma dos municípios de acordo com o percentual de UPAs que fazem parte de cooperativas, safra 1995/96.

35 Estado de São Paulo: distribuição geográfica e histograma dos municípios de acordo com o percentual de UPAs que fazem parte de associações, safra 1995/96.

36 Estado de São Paulo: distribuição geográfica e histograma dos municípios de acordo com o percentual de UPAs que fazem parte de sindicatos, safra 1995/96.

37 Estado de São Paulo: distribuição geográfica e histograma dos municípios de acordo com o capital social (medido como o valor máximo entre os percentuais de UPAs que fazem parte de cooperativas, associações e sindicatos), safra 1995/96.

38 Estado de São Paulo: distribuição geográfica e histograma dos municípios de acordo com o número de agências bancárias por mil habitantes, 1995. 
39 Estado de São Paulo: distribuição geográfica e histograma dos municípios de acordo com o valor das operações de crédito (na forma logarítmica) nas instituições financeiras do município em 1995, em Reais de dezembro de 2000.

40 Estado de São Paulo: distribuição geográfica e histograma dos municípios de acordo com o valor da receita (na forma logarítmica) da produção animal e vegetal na safra 1995/96, em milhares de Reais.

41 Estado de São Paulo: distribuição geográfica e histograma dos municípios de acordo com o total de ocorrências de crimes contra o patrimônio, por habitante, 1997.

42 Estado de São Paulo: distribuição geográfica e histograma dos municípios de acordo com o percentual da participação destes na arrecadação do ICMS, 1995.

43 Estado de São Paulo: distribuição geográfica e histograma dos municípios de acordo com a área das UPAs, em milhares de hectares, 1995.

44 Acurácia e precisão.

45 Municípios que apresentaram observações diagnosticadas como discrepantes.

46 Estado de São Paulo: distribuição geográfica e histograma dos municípios de acordo com a percentagem de UPAs que efetivamente receberam crédito rural, safra 1995/96.

47 Estado de São Paulo: distribuição geográfica e histograma dos municípios, de acordo com o modelo, da percentagem de UPAs que teriam recebido crédito rural, safra 1995/96.

48 Estado de São Paulo: estimativas concordantes e discordantes, considerando desvios de cinco e de dez pontos percentuais, referentes ao número de UPAs que receberam crédito rural, em percentagem, safra 1995/96. 


\section{LISTA DE TABELAS}

Página

1 Brasil: evolução da participação percentual média dos principais produtos de exportação no valor total exportado pelo país ao longo das décadas de 1821/30 a 1931/40 .....................................................

2 Brasil: valor médio (ponderado) dos contratos de crédito rural, por tipo de instituição financeira, concedidos entre janeiro de 1996 e dezembro de 2000

3 Brasil: distribuição percentual do crédito (rural) concedido por tipo de instituição, no período de janeiro de 1996 a dezembro de 2000 .

4 Brasil: gasto do setor público federal na agricultura (valor em Reais e participação percentual), por órgão governamental no ano de 1999

5 Brasil: estimativa da participação do consumo intermediário na agricultura em relação ao valor bruto de produção do setor, anos selecionados.

6 Brasil: estimativa das parcelas dos subsídios do programa de crédito rural financiadas pela dívida pública, expansão de base monetária e por depositantes do sistema bancário, de 1971 a 1981 (percentagens) 
7 Brasil: evolução do volume anual de financiamentos concedidos a produtores e cooperativas em operações de custeio, investimento e comercialização, realizadas pelo Banco do Brasil, por fonte de recursos, de 1997 a 1999, em milhares de Reais de 1999.

8 Brasil: evolução das despesas do Tesouro Nacional executadas com equalizações de taxas de juros e preços, 1997 a 1999, em milhares de Reais.

9 Principais características do velho e do novo paradigma de financiamento rural.

10 Principais instituições financeiras relacionadas ao microcrédito.

11 Variáveis que compõem o modelo.

12 Estado de São Paulo: municípios criados entre 1993 e 1996 e efetivamente instalados em 1997

13 Estado de São Paulo: média aritmética e medidas de dispersão das participações percentuais em cooperativas, associações e sindicatos e variável CAPSOC, por município, safra 1995/96.

14 Estado de São Paulo: coeficientes de correlação entre as participações percentuais em cooperativas, associações e sindicatos, por município, safra 1995/96.

15 Estado de São Paulo: média aritmética e medidas de dispersão das variáveis AGBCO, OPCRED e LPROD, por município, safra 1995/96.

16 Estado de São Paulo: média aritmética e medidas de dispersão das variáveis CRIMES, em 1997, ICMS e AREA, em 1995, por município.

17 Matriz de variâncias e covariâncias. 138

18 Estimadores obtidos em simulações para observar o impacto da multicolinearidade verificada nos dados analisados

19 Análise dos estimadores de máxima verossimilhança.

20 Estimativas de razão de chances. 
21 Associações entre as respostas observadas e as probabilidades

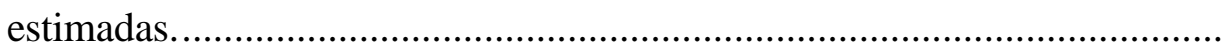

22 Estatísticas referentes às associações entre as respostas observadas e as probabilidades estimadas.

23 Municípios que apresentaram observações diagnosticadas como discrepantes.

24 Estado de São Paulo: média aritmética e medidas de dispersão dos percentuais de UPAs que receberam crédito rural, números reais e estimativas, por município. 


\title{
INFORMAÇÃO, CAPITAL SOCIAL E MERCADO DE CRÉDITO RURAL
}

\author{
Autor: ROBERTO ARRUDA DE SOUZA LIMA \\ Orientador: Prof. Dr. RICARDO SHIROTA
}

\section{RESUMO}

Este estudo analisa o efeito da informação e do capital social sobre o volume de negócios no mercado de crédito rural. Discute-se a conexão entre capital social e informação e como esta relação pode contribuir para a redução dos custos de transação da intermediação financeira, de modo a permitir aumento no volume de crédito rural. Para análise empírica, foi elaborado e testado um modelo econométrico (lógite) utilizando dados referentes ao Estado de São Paulo. Os dados foram obtidos de levantamentos estatísticos oficiais (censo agropecuário, LUPA e banco de dados do SEADE) referentes à safra 1995-1996. Os resultados indicam que o nível de capital social afeta o volume de crédito rural. Assim, incentivos, em especial com apoio do setor público, para formação e manutenção de capital social permitiriam aumento da eficiência da intermediação financeira e, em consequência, maior desenvolvimento do setor rural. 


\title{
INFORMATION, SOCIAL CAPITAL AND RURAL CREDIT MARKET
}

\author{
Author: ROBERTO ARRUDA DE SOUZA LIMA
}

Advisor: Prof. Dr. RICARDO SHIROTA

\section{SUMMARY}

This study analyses the effect of information and social capital on the volume of contracts in the rural credit market. It discusses the connection between social capital and information and how this relation contributes to the reduction of financial intermediation's transaction costs. A logit regression model was used to empirically test the effect of social capital on the volume of rural credit. The data, from the municipalities of the State of São Paulo, are from 1995 1996 official statistics (Farm Census, LUPA and SEADE's data basis). The results indicate that the level of social capital affects the amount of rural credit. Thus, incentives to further increase and maintain social capital would increment the efficiency of financial intermediation and, as a consequence, help rural sector's development. 


\title{
1 INTRODUÇÃO
}

No presente trabalho é analisado o papel do capital social na oferta de crédito rural. A importância desta discussão está baseada na idéia de que o mercado financeiro rural é relevante para o desenvolvimento da agricultura (Almeida, 1994; Banco Mundial, 1989). No entanto, na prática, a intermediação financeira ${ }^{3}$ enfrenta muitas ineficiências, o que reduz o volume de negócios, e, portanto, prejudica o processo de desenvolvimento da agricultura ${ }^{4}$. Assim, contribuições no sentido de combater as causas das ineficiências ou minimizar seus efeitos são interessantes para o mercado de crédito e, consequentemente, para a economia. A hipótese verificada neste estudo é que o capital social pode influir na intermediação financeira, contribuindo para sua maior eficiência.

\begin{abstract}
No caso do crédito rural, o intermediário financeiro maximizador de lucro depara com uma importante restrição: historicamente, a taxa de juros nesse mercado tem sido fixada pelo governo abaixo do ponto de equilíbrio. Assim, o problema relevante para o intermediário financeiro é a minimização do seu custo. Entretanto, financiar a agricultura é uma das operações de mais alto custo no mercado financeiro em razão da dispersão geográfica (dificuldades com supervisão, recuperação de créditos,
\end{abstract}

3 Intermediários financeiros são instituições responsáveis pela alocação de recursos de agentes financeiramente superavitários para agentes deficitários, isto é, para aqueles que necessitam de recursos de terceiros para condução de seus projetos (Banco Mundial 1989).

${ }^{4} \mathrm{O}$ desenvolvimento da agricultura é importante não apenas para os agentes diretamente ligados a este setor, mas para toda economia, ao assegurar a produção de alimentos e matérias-primas (a preços que não representem pressão inflacionária), além da geração de excedentes exportáveis. 
obtenção de informações, entre outras), problemas com garantias, pequeno tamanho dos empréstimos e os riscos inerentes à atividade rural (Adams, 1984). Custos elevados e a limitação da taxa de juros não incentivam as instituições financeiras a realizar aplicações no financiamento da agricultura.

Os importantes avanços teóricos, verificados nas últimas décadas do século XX, referentes à informação ${ }^{5}$ e capital social, permitem o desenvolvimento de novas soluções para o desenvolvimento do mercado de crédito. Em especial, a crescente utilização destes conceitos favoreceu o crescimento, quantitativo e qualitativo, das operações de microcrédito (urbano e rural). O capital social pode elevar a confiança dos credores no resultado de suas operações, facilitando a geração de maior número de negócios.

Ao analisar as relações entre informação, capital social e oferta de crédito, o presente estudo busca contribuir para que ocorra aumento da eficiência da intermediação financeira e, em conseqüência, venha ocorrer maior oferta de recursos para a agricultura.

Além da análise dos aspectos teóricos dessas relações, inclusive discutindo a evolução do crédito rural no Brasil, este estudo elabora e testa (em caráter pioneiro) um modelo econométrico para verificar como o capital social afeta a probabilidade de um agricultor ter acesso a crédito rural ${ }^{6}$.

\footnotetext{
${ }^{5}$ Nomeadamente, no que diz respeito à sua assimetria. Esta decorre do fato de que os emprestadores não têm o mesmo nível de informação que os tomadores a respeito das características e possibilidades de sucesso dos empreendimentos financiados (Araújo, 1996). O comportamento do tomador não é perfeitamente observável por parte do emprestador.

${ }^{6}$ Para estimativa do modelo proposto foram utilizados dados referentes ao Estado de São Paulo.
} 


\subsection{Objetivos}

O objetivo geral do presente estudo está centrado no entendimento de como informação e capital social afetam o volume de negócios praticados no mercado de crédito rural.

Especificamente, os objetivos são:

i) descrever e analisar a atual estrutura de organização do financiamento à agricultura brasileira;

ii) avaliar a relevância da informação na determinação dos custos destes financiamentos e, consequentemente, na eficiência da intermediação financeira;

iii) avaliar a importância do capital social para a minimização dos custos de transação; e,

iv) verificar econometricamente a influência do capital social na oferta de crédito rural.

Espera-se que os resultados obtidos contribuam não apenas para os intermediários financeiros e produtores rurais, mas também para os formuladores de políticas econômicas e para aqueles interessados no estudo acadêmico da intermediação financeira, em especial no mercado de crédito rural. 


\subsection{Organização do trabalho}

Este trabalho está organizado em nove capítulos. O capítulo 2 contém uma revisão sobre o crédito rural no Brasil, sua evolução e situação atual. Em particular, é analisada a interação entre as políticas macroeconômicas e a política de crédito rural no Brasil.

O capítulo 3 apresenta as bases teóricas da intermediação financeira, em especial os aspectos referentes aos custos de transação, destacando a inadimplência. A escolha de parte das variáveis explanatórias do modelo analisado é justificada pela teoria discutida neste capítulo.

O capítulo 4 descreve e analisa a atual estrutura do financiamento à agricultura, respondendo ao primeiro objetivo específico deste trabalho, com base nos tópicos discutidos nos dois capítulos anteriores.

O capítulo 5 complementa a base teórica do trabalho, abordando os conceitos de informação e de capital social. Além da definição destes conceitos, são discutidas as diversas metodologias apresentadas na literatura para mensuração do capital social. A discussão teórica realizada neste capítulo justifica a escolha das demais variáveis explanatórias utilizadas no modelo analisado.

No capítulo 6 são apresentadas as premissas para a formulação da hipótese que direciona este trabalho. $\mathrm{O}$ conceito de confiabilidade é introduzido, sintetizando a relação sugerida entre informação e capital social. Na sequiência do capítulo é discutido como a confiabilidade pode afetar a oferta de crédito. 
O capítulo 7 apresenta a hipótese sobre o volume de crédito rural e o modelo empírico utilizado. Além disso, definem-se as variáveis utilizadas e são discutidos os tratamentos que se fizeram necessários na coleta e utilização dos dados.

Os resultados das análises deste estudo são apresentados e discutidos no capítulo 8. A estimativa do lógite e a qualidade do ajuste do modelo são, também, apresentados neste capítulo. $\mathrm{O}$ efeito das diversas variáveis explanatórias, em especial a que capta o capital social, sobre o volume de operações de crédito rural é discutido, assim como os fatores que afetam a estimativa realizada.

O capítulo 9 conclui o estudo, destacando os principais resultados obtidos e as considerações finais sobre o problema discutido. Além disso, o capítulo contém discussões sobre as limitações do trabalho e sugestões de futuras pesquisas. 


\section{EVOLUÇÃO E SITUAÇÃO ATUAL DO CRÉDITO RURAL NO BRASIL}

\subsection{Evolução do crédito rural no Brasil}

Do descobrimento do Brasil até meados do século XIX, a dinâmica do setor rural brasileiro era bastante simples, determinada pelas flutuações do comércio exterior (Kageyama et al., 1990). Uma série de grandes ciclos de exportação primária determinaram o crescimento econômico do Brasil (Baer, 1996), destacando-se o paubrasil, a cana-de-açúcar, o algodão, o fumo, o cacau, a borracha e o café (Tabela 1). O produto que internacionalmente fosse atrativo (preço e quantidade demandada) determinava a alocação dos recursos (homens, animais de trabalho e terras) de modo a incrementar a produção de exportação. Mesmo no final do século XVIII, quando ocorreu o chamado ciclo do ouro, a agricultura permaneceu como o principal setor exportador do Brasil (Figura 1). O mercado interno praticamente inexistia (Kageyama et al., 1990).

As características da economia e da atividade agrícola foram alteradas a partir de 1850, com a suspensão do tráfico negreiro e a introdução do trabalho livre nas fazendas de café. Ampliaram-se as atividades urbanas e outras começaram a emergir (Kageyama et al., 1990). A urbanização (e, posteriormente, a industrialização) aliada às 
necessidades do comércio exterior resultaram em políticas ${ }^{7}$ que buscavam atender aos interesses das oligarquias rurais tradicionais, isto é, aos setores ligados ao modelo primário exportador, afetado por estas alterações sócio-econômicas.

Tabela 1. Brasil: evolução da participação percentual média dos principais produtos de exportação no valor total exportado pelo país ao longo das décadas de $1821 / 30$ a 1931/40.

\begin{tabular}{cccccccccc}
\hline Decênio & Café & Açúcar & Cacau & $\begin{array}{c}\text { Erva- } \\
\text { mate }\end{array}$ & Fumo & $\begin{array}{r}\text { Algodão } \\
\text { em pluma }\end{array}$ & Borracha & $\begin{array}{c}\text { Couro } \\
\text { e peles }\end{array}$ & Subtotal \\
\hline $1821 / 30$ & 18,4 & 30,1 & 0,5 & - & 2,5 & 20,6 & 0,1 & 13,6 & 86,8 \\
$1831 / 40$ & 43,8 & 24,0 & 0,6 & 0,5 & 1,9 & 10,8 & 0,3 & 7,9 & 89,8 \\
$1841 / 50$ & 41,4 & 26,7 & 1,0 & 0,9 & 1,8 & 7,5 & 0,4 & 8,5 & 88,2 \\
$1851 / 60$ & 48,8 & 21,2 & 1,0 & 1,6 & 2,6 & 6,2 & 2,3 & 7,2 & 90,9 \\
$1861 / 70$ & 45,5 & 12,3 & 0,9 & 1,2 & 3,0 & 18,3 & 3,1 & 6,0 & 90,3 \\
$1871 / 80$ & 56,6 & 11,8 & 1,2 & 1,5 & 3,4 & 9,5 & 5,5 & 5,6 & 95,1 \\
$1881 / 90$ & 61,5 & 9,9 & 1,6 & 1,2 & 2,7 & 4,2 & 8,0 & 3,2 & 92,3 \\
$1891 / 00$ & 64,5 & 6,0 & 1,5 & 1,3 & 2,2 & 2,7 & 15,0 & 2,4 & 95,6 \\
$1901 / 10$ & 51,3 & 1,2 & 2,8 & 2,9 & 2,4 & 2,1 & 28,2 & 4,3 & 95,2 \\
$1911 / 20$ & 53,0 & 3,0 & 3,6 & 3,0 & 2,6 & 2,0 & 12,1 & 6,2 & 85,5 \\
$1921 / 30$ & 69,6 & 1,4 & 3,2 & 2,7 & 2,1 & 2,4 & 2,6 & 4,6 & 88,6 \\
$1931 / 40$ & 52,4 & 0,4 & 4,1 & 1,7 & 1,6 & 13,9 & 1,0 & 4,4 & 79,5 \\
\hline
\end{tabular}

Fonte: Albuquerque \& Nicol (1987)

\footnotetext{
${ }^{7}$ Exemplo destas políticas foram os ganhos garantidos pelo Governo e isenções de tarifas de importação de equipamentos. Estes incentivos foram direcionados para investimentos em usinas de açúcar capitalizadas (Baer, 1996).
} 


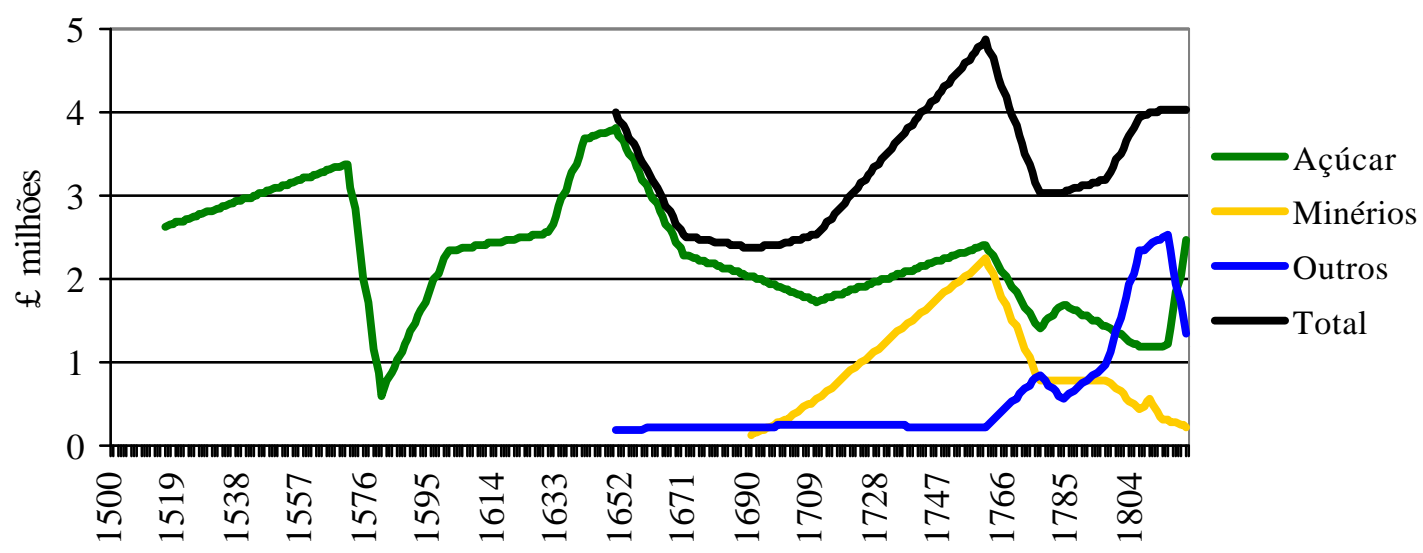

Figura 1 - Brasil: estimativa da evolução das exportações de diferentes produtos entre 1500 e 1820, em milhões de Libras.

Fonte: Simonsen (1944)

As primeiras tentativas de se criar uma política de crédito rural no Brasil ocorreram no início do século passado, com o crescimento das lavouras cafeeiras. No entanto, medidas concretas só foram implementadas em 1937. Naquele ano foi criada a Carteira de Crédito Agrícola e Industrial (CREAI) do Banco do Brasil ${ }^{8}$. Neste mesmo ano foi publicada a Lei $\mathrm{n}^{\circ} 492$ regulamentando o Penhor Rural, que havia sido introduzido na legislação brasileira em 1885 (Lei n 3272).

\footnotetext{
${ }^{8}$ A Lei $\mathrm{n}^{\circ}$ 454, de 09/07/37, que deu origem à CREAI, determinava o fornecimento de recursos para a agropecuária. A fonte dos recursos, em sua maior parte, eram as operações na Carteira de Redesconto. Não houve uma fonte específica de financiamento para a agricultura até os anos 50 e o valor e número de contratos efetuados durante a década de 40 não foram significativos. Em 1952, a CREAI passou por transformações, criando diversas novas linhas de financiamento. Foram utilizadas as seguintes fontes de recursos: o encaixe do Banco do Brasil; os recursos obtidos através do redesconto dos contratos de financiamento, de letras hipotecárias e bônus emitidos pelo Banco do Brasil; depósitos previstos em lei; garantia para execução de contratos firmados; recursos dos Institutos de Previdência; e, tributos e contribuições destinados ao financiamento do setor rural (Massuquetti, 1998).
} 
Nesse período, as políticas governamentais voltadas para o setor agrícola foram implementadas em torno de institutos criados para cuidar de produtos específicos (Instituto Brasileiro do Café - IBC, Instituto do Açúcar e Álcool - IAA, Comissão Especial da Lavoura Cacaueira - CEPLAC, entre outros). Assim, não havia uma política voltada ao setor agrícola como um todo, mas apenas aos setores voltados à exportação. Desta forma, o volume de recursos destinados ao financiamento rural e o número de contratos efetuados até o final dos anos 60 não foram significativos (Figura 2).

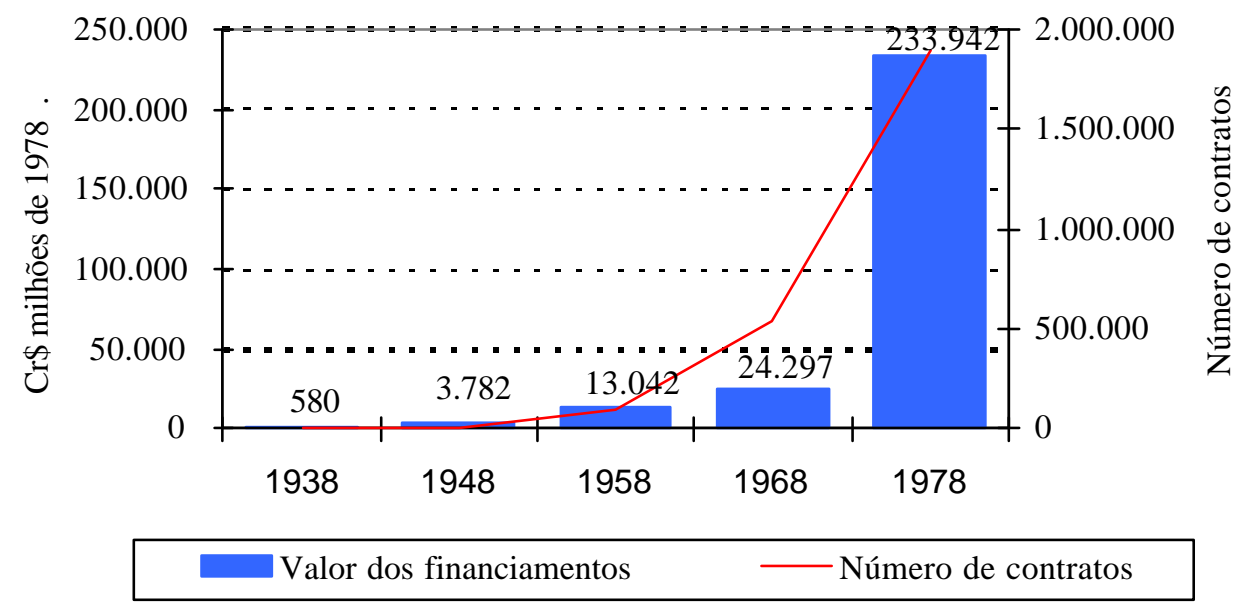

Figura 2 - Brasil: número de contratos e valor dos financiamentos (em Cr\$ milhões de 1978) destinados à agropecuária nos anos de 1938, 1948, 1958, 1968 e 1978.

Fonte: Massuquetti (1998)

A partir dos anos 50, o setor rural passa por um período de transformações e reestruturações, buscando não somente o crescimento extensivo da produção agrícola, mas também a modernização de sua base técnica (Guilhoto et al., 
2000). A institucionalização do crédito rural no Brasil $^{9}$ e a determinação da obrigatoriedade de empréstimo à agricultura de um determinado percentual sobre os depósitos à vista do sistema bancário ${ }^{10}$ permitiram uma forte expansão do crédito rural até o final dos anos 70 (Figura 3). Como conseqüência, no período entre 1969 e 1979, o volume das aplicações de recursos de crédito rural cresceu $16,41 \%$ a.a. em termos reais. Este expressivo aumento da disponibilidade de crédito tem sua dimensão ressaltada quando se verifica que na base do período o volume já era significativo. Em 1970, o crédito rural correspondia a 54\% do produto do setor primário (Kageyama et al., 1990). Este crescimento foi impulsionado pela forte presença do setor público e pela aplicação compulsória dos bancos. A oferta de recursos apoiou-se, também, na disponibilidade de financiamento externo a custo relativamente baixo ${ }^{11}$ e em uma política fiscal pouco restritiva (Vellutini, 1991).

O início da década de 80 caracterizou-se pelo esgotamento do processo de industrialização via substituição de importações, pela crise da dívida externa e a conseqüente interrupção do fluxo de poupança externa. A capacidade de poupança do setor público se exauriu e a inflação atingiu níveis politicamente insustentáveis (Barros \& Araujo, 1995). A oferta de crédito oficial, então, reduziu-se drasticamente ${ }^{12}$ e foram buscadas novas alternativas de financiamento, com fontes não inflacionárias de recursos.

\footnotetext{
${ }^{9}$ Lei no 4829 , de 05/11/65.

10 A chamada exigibilidade bancária, instituída pela Resolução 69 do Banco Central do Brasil, de 22/09/67.

11 A prime rate (EUA), que foi de 4,535\% a.a. em 1965, apresentou forte crescimento no final dos anos 70 e início dos anos 80, quando passou de 6,82\% a.a. (em 1977) para 18,87\% a.a. (em 1981).

12 No período de 1980 a 1990 ocorreu uma redução média de 5,8\% a.a. no volume das aplicações de recursos de crédito rural.
} 


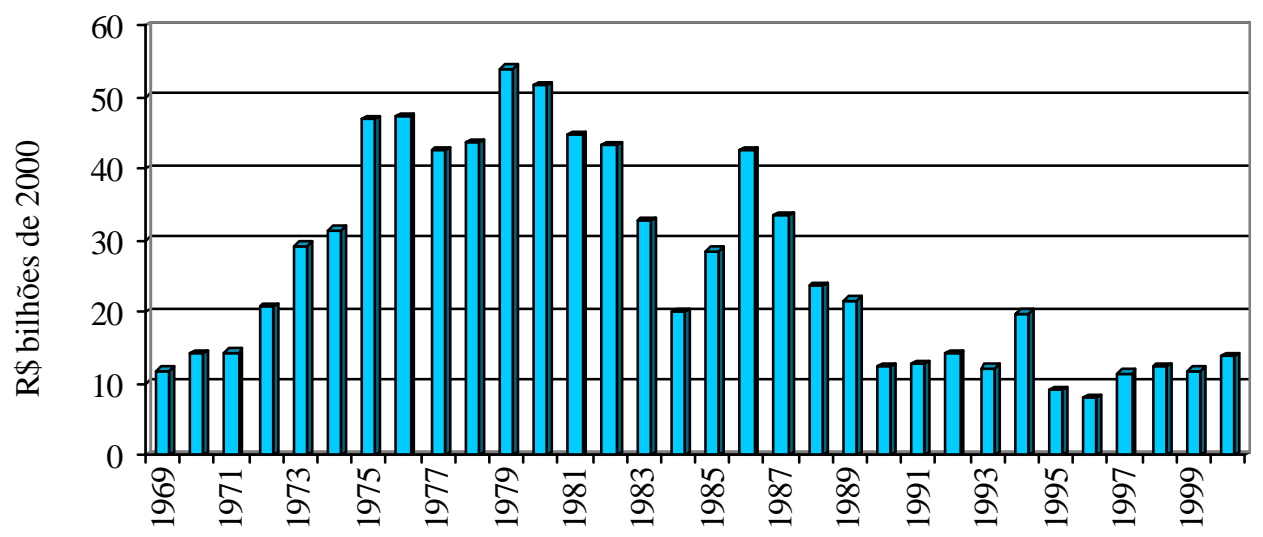

Figura 3 - Brasil: evolução do volume anual de recursos destinados ao crédito rural, 1969 a 2000, em bilhões de Reais de 2000.

Fonte: Banco Central do Brasil - BACEN (2001)

Nota: Deflacionado pelo Índice Geral de Preços - Disponibilidade Interna (IGP-DI), elaborado pela Fundação Getúlio Vargas (FGV). Base: média do ano 2000.

A busca por novas alternativas para o financiamento da produção agropecuária pode ser observada, também, em diversas partes do mundo ${ }^{13}$. Nos países em desenvolvimento, a necessidade de criação de alternativas de financiamento é mais intensa. Razões de ordem estrutural, destacando-se o desequilíbrio fiscal, direcionam a economia para maior participação do setor privado em áreas antes restritas ao setor público (Biasoto Junior \& Magalhães Junior, 1998). E, este direcionamento é mais forte quanto menor a capacidade do setor público em gerar poupança. Este é o caso do Brasil,

\footnotetext{
${ }^{13}$ Nos Estados Unidos, por exemplo, em 1983, o setor privado respondia por menos da metade dos financiamentos agrícolas (apenas 32\% do crédito provinha de bancos, seguradoras, fornecedores ou comerciantes). Atualmente, ele responde pelo maior volume dos financiamentos $(70 \%$ do crédito à agricultura são totalmente privados, sendo que os bancos comerciais fornecem cerca de $40 \%$, as seguradoras aproximadamente $7 \%$ e os indivíduos, comerciantes e fornecedores de insumos os demais 23\%), destacando-se a crescente participação de indústrias e comerciantes ligados à agricultura como fontes de crédito agrícola (Guedes Filho, 1999).
} 
onde a saída do Estado como ofertante de crédito tem forçado o setor privado não financeiro a financiar os agricultores. Estes, pouco capitalizados, muitas vezes dependem de recursos de terceiros. Em muitos casos, inclusive, necessitam comprometer, antecipadamente, parte do produto de sua atividade ${ }^{14}$ para fazer frente às despesas de produção. Assim, o setor produtivo (indústrias de defensivos, por exemplo) muitas vezes só consegue realizar suas vendas ao conceder prazo (ou seja, crédito), adequando-se ao fluxo de caixa dos agricultores.

Em resumo, a intermediação no financiamento da agricultura brasileira tem sido realizada tanto por instituições financeiras quanto por empresas comerciais e industriais, a montante e a jusante do produtor rural. Porém, obstáculos como a assimetria de informações nos mercados financeiros, a seletividade intrínseca à concessão de créditos e a fungibilidade ${ }^{15}$ do dinheiro, entre outros, devem ser superados para o desenvolvimento de um eficiente sistema de financiamento (Araujo, 1999). Adicionalmente, deve-se dar atenção especial às características do crédito rural que o distingue de outras modalidades de crédito.

A especificidade do período de produção agrícola caracteriza-se por dois fatores que implicam em um giro mais lento dos capitais aplicados no setor, quando comparado a aplicações em processos de produção contínuos (Delgado, 1985). Uma vez iniciado o investimento na produção é preciso aguardar a conclusão de todo processo produtivo (do preparo do solo até a colheita e comercialização). Não é possível uma interrupção do processo sem perdas significativas. Além deste fato, mesmo quando concluído o período de produção de um produto agrícola, em geral não há renovação imediata do processo. Novo processo somente será iniciado em épocas preestabelecidas no calendário agrícola, que variam de acordo com o produto e com eventos climáticos (temperatura, precipitação pluviométrica, etc.). No caso do Brasil, a maior parte das

\footnotetext{
${ }^{14}$ Venda antecipada ou oferta, em garantia, da safra pendente.

15 Fungibilidade é uma das principais características da moeda moderna. Significa a possibilidade de intercâmbio de unidades de moeda. Os empréstimos agrícolas são essencialmente fungíveis (Von Pischke \& Adams, 1983).
} 
culturas iniciam o processo produtivo no segundo semestre e são colhidas no primeiro semestre. Isto implica em sazonalidade das operações de crédito rural, com volumes mais elevados no segundo semestre de cada ano (Figura 4). A Figura 5 mostra a variação do índice sazonal ${ }^{16}$ do volume de crédito rural no Brasil. Nessa figura está representado, também, para cada mês, um intervalo indicativo da dispersão dos índices estacionais ${ }^{17}$.

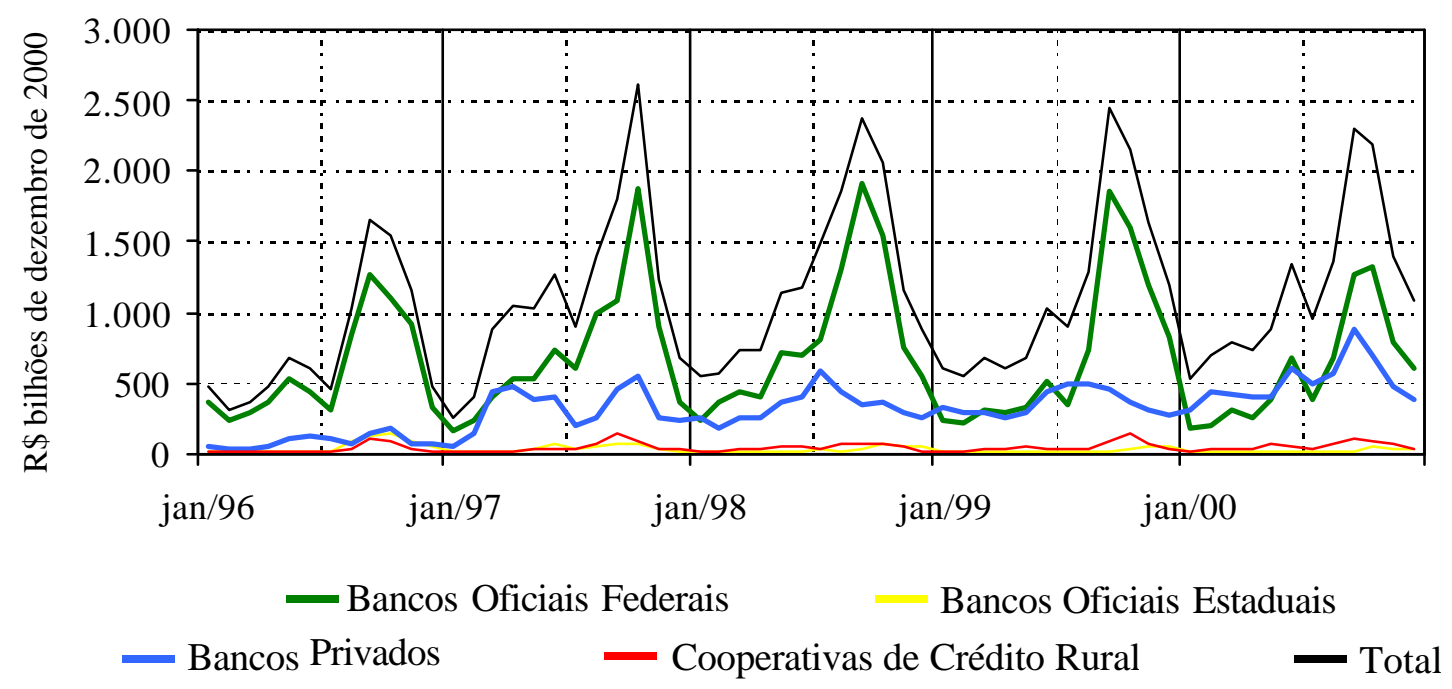

Figura 4 - Brasil: evolução do volume mensal de crédito rural concedido, por tipo de instituição financeira, janeiro de 1996 a dezembro de 2000, em milhões de Reais de dezembro de 2000.

Fonte: BACEN (2001)

Nota: Deflacionado pelo IGP-DI/FGV.

\footnotetext{
16 Índice sazonal obtido pelo método da média geométrica móvel centralizada utilizando valores do período de janeiro de 1996 a dezembro de 2000, conforme metodologia apresentada em Hoffmann (1980).

${ }^{17}$ Os limites, superior e inferior, são obtidos multiplicando e dividindo o índice sazonal pelo índice de irregularidade, conforme metodologia apresentada em Hoffmann (1980).
} 


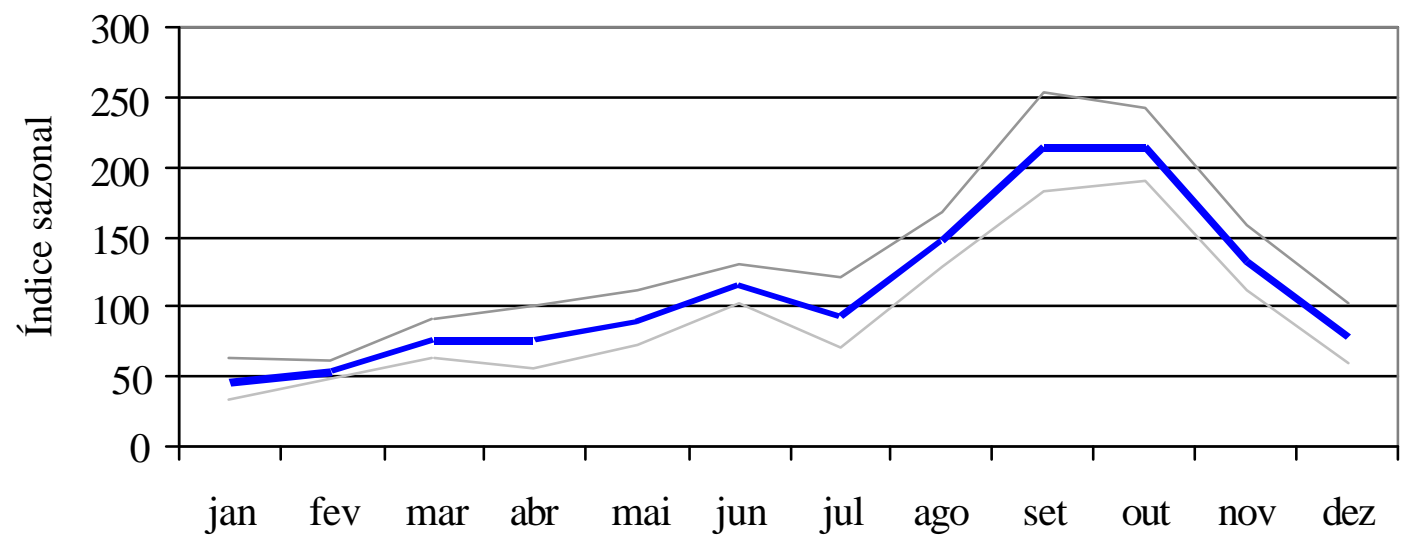

Figura 5 - Brasil: variação do índice sazonal do volume de crédito rural, janeiro de 1996 a dezembro de 2000.

Deve-se destacar que, para reduzir custos, os bancos buscam realizar operações de valores mais altos, o que é refletido no valor médio de seus contratos ${ }^{18}$. Este maior volume por contrato pode ser explicado por, pelo menos, duas razões. Primeiro, grandes agricultores, em muitos casos, apresentam mais e melhores garantias aos bancos, reduzindo o risco. Adicionalmente, o custo bancário de transação ${ }^{19}$ é menor nos grandes empréstimos (Barros \& Araujo, 1995).

Os picos dos valores médios de contratos realizados pelos bancos privados ocorrem no início do ano, época que responde pelo menor volume total de

18 Os bancos oficiais, embora tenham, como os bancos privados, objetivos de maximizar lucros, são sensíveis aos objetivos políticos. Para alcançarem objetivos sociais (como o estímulo à produção de alimentos e o apoio aos pequenos e médios agricultores) podem apresentar comportamento diferente do setor privado (Araujo, 1980).

${ }^{19}$ Custos de transação podem ser definidos como os custos ex-ante de esboçar, negociar e salvaguardar um acordo, somados aos custos ex-post, como os de monitoramento e os decorrentes de problemas da adaptação que surge quando a execução do contrato não é certa, como resultado de atrasos, erros e omissões. São custos não diretamente relacionados à produção, mas que surgem a medida que os agentes se relacionam entre si e problemas de coordenação de suas ações emergem (Farina et al., 1997). Restringindo o conceito ao sistema bancário, pode-se definir os custos de transação como aqueles representados pelos custos administrativos, custo de capital, e as perdas por inadimplência (Guidetti \& Araujo, 1994). 
crédito concedido (Figura 6). Considerando o volume (em reais) de crédito concedido a cada mês como peso, foi calculada a média ponderada do valor os contratos referente aos 60 meses analisados (Tabela 2). Há uma significativa diferença entre o valor médio dos contratos concedidos por bancos privados (cerca de $\mathrm{R} \$ 25$ mil) e pelas demais instituições (variando de $\mathrm{R} \$ 7$ a 11 mil). O valor médio correspondente aos bancos privados foi, no período analisado, $197 \%$ superior ao dos bancos oficiais federais.

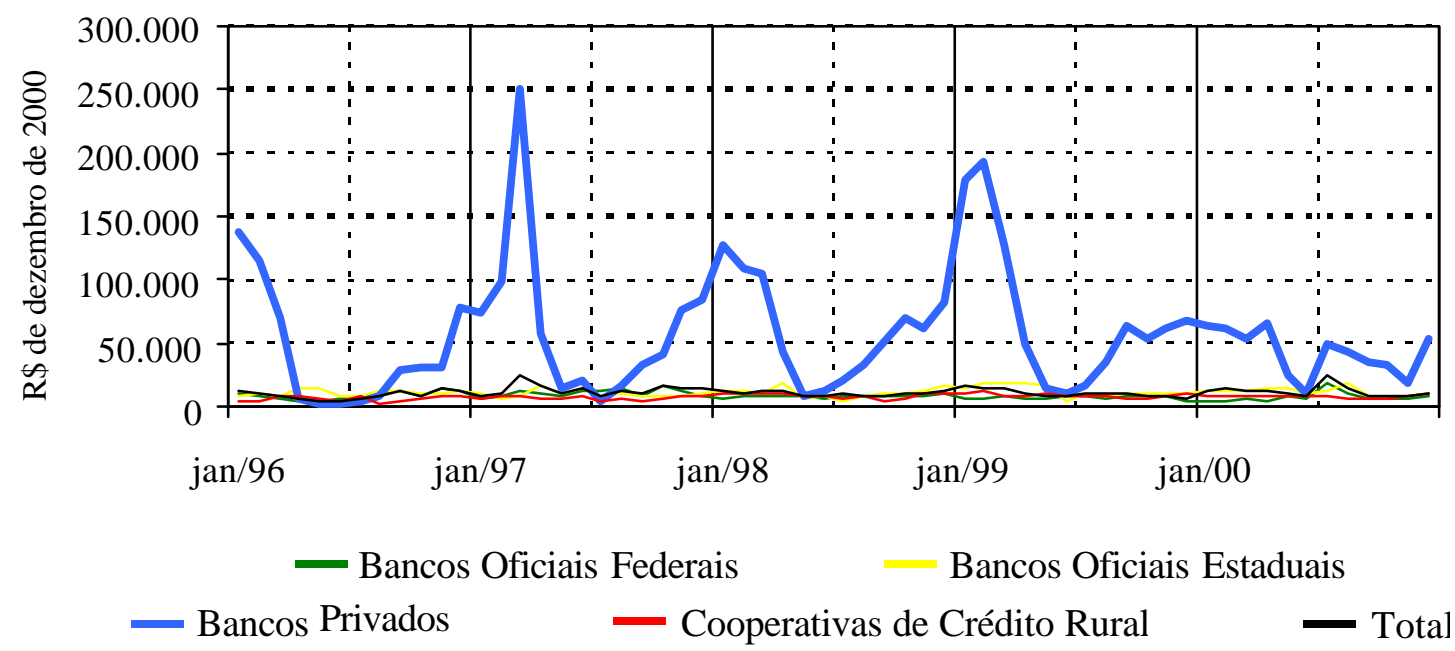

Figura 6 - Brasil: evolução do valor médio mensal dos contratos de crédito rural, por tipo de instituição financeira, janeiro de 1996 a dezembro de 2000 (em de Reais de dezembro 2000).

Fonte: BACEN (2001)

Nota: Deflacionado pelo IGP-DI/FGV. 
Tabela 2. Brasil: valor médio (ponderado) dos contratos de crédito rural, por tipo de instituição financeira, concedidos entre janeiro de 1996 e dezembro de 2000.

\begin{tabular}{ll}
\hline Financiador & Valor Médio \\
\hline Bancos Oficiais Federais & $\mathrm{R} \$ 8.479,37$ \\
Bancos Oficiais Estaduais & $\mathrm{R} \$ 10.806,76$ \\
Bancos Privados & $\mathrm{R} \$ 25.194,25$ \\
Cooperativas de Crédito Rural & $\mathrm{R} \$ 7.262,82$ \\
Média Geral & $\mathrm{R} \$ 10.561,73$ \\
\hline
\end{tabular}

Fonte: BACEN (2001)

Assim sendo, observa-se uma divisão na forma de atuação ${ }^{20}$. Os bancos privados atendendo poucos tomadores mas em grandes volumes (ou seja, com elevado valor médio dos contratos) e as demais instituições realizando grande número de contratos (com baixo valor médio). A Tabela 3 destaca esta característica. Isto é um indicador de que uma oferta realizada apenas por bancos privados poderia estar limitada a poucos agricultores, não atendendo à agricultura como um todo.

Outra característica do crédito rural no Brasil é que o acesso aos recursos tem sido bastante restrito. De acordo com a legislação do Sistema de Crédito Rural, este deveria ser um mecanismo garantidor de maior disponibilidade de recursos ao setor agrícola (Melo, 1983). Nos anos 70, apenas 15\% dos estabelecimentos rurais obtiveram algum tipo de financiamento de fontes institucionais ou não (Araujo, 1983). Dados do último Censo Agropecuário, referente ao ano agrícola 1995/96, apontam que apenas

\footnotetext{
20 Trata-se de uma tendência relativa não apenas ao crédito rural, mas a todo mercado financeiro (Pequenos sem crédito, 2002).
} 
$5,3 \%$ dos proprietários rurais contraíram empréstimos para o desenvolvimento e expansão de suas atividades, e 4,1\% conseguiram crédito para custeio.

Tabela 3. Brasil: distribuição percentual do crédito (rural) concedido por tipo de instituição, no período de janeiro de 1996 a dezembro de 2000.

\begin{tabular}{lcc}
\hline Financiador & Valor (R\$) & $\mathrm{N}^{\mathrm{o}}$ Contratos \\
\hline Bancos Oficiais Federais & $62,2 \%$ & $77,4 \%$ \\
Bancos Oficiais Estaduais & $3,5 \%$ & $3,4 \%$ \\
Bancos Privados & $29,8 \%$ & $12,5 \%$ \\
Cooperativas de Crédito Rural & $4,6 \%$ & $6,7 \%$ \\
\hline
\end{tabular}

Fonte: BACEN (2001)

Nota: Elaborado a partir de valores mensais deflacionados pelo IGP-DI/FGV.

Analisando o período de 1970 a 1993, observa-se que a concentração regional do crédito rural foi acentuada. A soma dos recursos ofertados às regiões Sul, Sudeste e Centro-Oeste atingiram cerca de $90 \%$ do total. Para as regiões Norte e Nordeste foram direcionadas quantidades pouco expressivas para o financiamento agrícola $^{21}$ (Sperl \& Araujo, 1995). Essa situação pode ser explicada, em parte, pela distribuição da produção comercial. Logo após a instituição do SNCR houve maior concentração nas regiões Sul e Sudeste. Somente a partir do final dos anos setenta, com

21 Mesmo com a criação dos Fundos Constitucionais de Financiamento do Nordeste (FNE) e do Norte (FNO), em 1988, não houve alteração no padrão distributivo do crédito rural no Brasil (Sperl \& Araujo, 1995). 
o deslocamento da fronteira agropecuária, é que foi elevado o volume de crédito concedido para região Centro-Oeste (Hoffmann \& Kageyama, 1987). Além disso, a concentração regional das operações de crédito foi afetada pelas seguintes razões: o pequeno grau de interiorização da rede bancária brasileira; a concentração desta rede nas regiões mais prósperas do país; e, o tipo e lavouras que predominam no sul do país (como soja e trigo), particularmente exigentes em termos de fertilizantes e defensivos (Agroanalysis, 1979).

\subsection{Políticas macroeconômicas e a política de crédito rural no Brasil}

O entendimento do comportamento da oferta de crédito rural, brevemente apresentada no item anterior (Figura 3) e detalhada a seguir, só é possível através de uma revisão da evolução econômica do Brasil. Há uma interação entre políticas macroeconômicas e agricultura, em especial durante o processo inflacionário (Barros, 1993; Sayad, 1979). A política agrícola quase sempre buscou o crescimento da agropecuária não com objetivos prioritários no próprio setor, mas para atender a objetivos de equilíbrio interno (em especial, o controle da inflação) e externo da economia como um todo (Barros, 1982). Exemplo deste vínculo pode ser observado na distribuição dos gastos e das responsabilidades dos diferentes órgãos públicos com relação ao setor agrícola. O Ministério da Fazenda destaca-se como a principal fonte de recursos (Tabela 4) e como principal responsável pela política agrícola ${ }^{22}$.

\footnotetext{
22 Em 1999, onze subprojetos e subatividades do Ministério da Fazenda respondiam pela parte mais relevante da política agrícola, incluindo as Aquisições do Governo Federal (AGF), custeio agropecuário, Programa de Revitalização de Cooperativas (RECOOP) e o segmento de crédito do Programa Nacional de Fortalecimento da Agricultura Familiar - PRONAF. Ao Ministério da Agricultura restava a responsabilidade por programas como eletrificação rural e irrigação (Gasques, 2001).
} 
Tabela 4. Brasil: gasto do setor público federal na agricultura (valor em Reais e participação percentual), por órgão governamental no ano de 1999.

\begin{tabular}{lcc}
\hline Órgão Superior & Gasto em R\$ & $\begin{array}{c}\text { Participação } \\
(\%)\end{array}$ \\
\hline Ministério da Fazenda & 3.466 .220 .010 & 43,36 \\
Ministério da Agricultura e do Abastecimento & 2.666 .396 .529 & 33,35 \\
Ministério da Política Fundiária e do Desenvolv. Agrário & 1.345 .003 .579 & 16,82 \\
Ministério da Integração Social & 449.113 .722 & 5,62 \\
Ministério do Meio Ambiente & 22.275 .074 & 0,28 \\
Ministério da Defesa & 19.702 .644 & 0,25 \\
Gabinete da Presidência da República & 18.879 .792 & 0,24 \\
Ministério da Educação & 3.235 .637 & 0,04 \\
Ministério da Ciência e Tecnologia & 2.072 .684 & 0,03 \\
Ministério do Desenvolv., Indústria e Comércio Exterior & 1.000 .000 & 0,01 \\
Ministério das Relações Exteriores & 9.994 .915 .252 & 100,00 \\
\hline
\end{tabular}

Fonte: Gasques (2001)

O período inicial relevante para a presente análise (primeira metade do século XX) foi marcado por duas Guerras Mundiais e pela Crise de 1929, que afetaram fortemente o comércio e os fluxos internacionais de capital e de mão-de-obra (imigração). Neste contexto, as economias dos países latino-americanos passaram de um 
modelo econômico primário, voltado para o mercado externo, para um modelo urbanoindustrial (Garcia \& Goldbaum, 2001). A partir de 1930 o Brasil experimentou um processo de integração dos mercados (de alimentos, de trabalho e de matérias primas) e de modernização, culminando com a chamada fase de industrialização pesada a partir de 1955 (Kageyama et al., 1990). A modernização da agricultura brasileira é definida como uma mudança na base técnica de produção em que há a substituição da produção artesanal por uma agricultura moderna e intensiva, com a introdução de maquinários, de elementos químicos (fertilizantes, defensivos, etc.), novas ferramentas e culturas (Guilhoto et al., 2000). O processo de modernização pode ser medido pela participação do consumo intermediário ${ }^{23}$ no valor da produção agrícola (Tabela 5), indicando a dependência da agricultura de compras industriais para produção de suas mercadorias. Ou seja, quanto mais complexa se torna a base técnica da produção, com a utilização crescente de insumos (químicos, físicos e biológicos) maior tende a ser a proporção de consumo intermediário.

A medida que o país tornava-se mais moderno, maior se tornava a participação do setor industrial na renda do Brasil (Figura 7). A redução da participação da agricultura no Produto Interno Bruto (PIB) alterou o foco da política macroeconômica. A agricultura deixou de ser um problema de crescimento para ser de estabilidade, face a importância do setor tanto na formação de salários (via custo de alimentação e vestuário) quanto na geração de divisas (Barros, 1982).

${ }^{23}$ Consumo intermediário é o valor de todos insumos de bens e serviços que entram e desaparecem no processo de produção. Englobam as despesas com sementes, defensivos, fertilizantes, rações e medicamentos para animais, aluguel de máquinas, embalagens e outros itens que possam ser considerados matérias primas ou insumos produtivos (Guilhoto et al., 2000; Kageyama et al., 1990). 
Tabela 5. Brasil: estimativa da participação do consumo intermediário na agricultura em relação ao valor bruto de produção do setor, anos selecionados.

\begin{tabular}{cc}
\hline Ano & Consumo intermediário \\
\cline { 2 - 2 } & Valor Produção \\
\hline 1939 & $10,0 \%$ \\
1949 & $11,1 \%$ \\
1954 & $13,2 \%$ \\
1959 & $14,3 \%$ \\
1965 & $21,5 \%$ \\
1968 & $25,1 \%$ \\
1970 & $27,6 \%$ \\
1975 & $34,4 \%$ \\
1980 & $38,7 \%$ \\
\hline
\end{tabular}

Fonte: Kageyama et al. (1990)

Nos anos 50, o principal objetivo das políticas públicas voltadas ao setor agropecuário, foi a exploração de excedentes exportáveis (café, algodão e cacau) para financiar o desenvolvimento industrial ${ }^{24}$. Neste período de industrialização do Brasil, que se estende até o início dos anos 60, predominava a visão estruturalista ${ }^{25}$ entre os economistas latino-americanos.

24 Sustentando esta política, o país operava com um sistema de taxas de câmbio múltiplas, que discriminavam as exportações tradicionais enquanto favoreciam as importações de maquinários e de bens de capital (Baer, 1996).

${ }^{25} \mathrm{O}$ estruturalismo está associado à escola de pensamento da CEPAL (Comissão Econômica para América Latina e Caribe da Organização das Nações Unidas). O estruturalismo analisava a inserção internacional e os condicionantes internos (as "estruturas") das economias nacionais a partir de uma concepção que opõe economias centrais (Europa, Estados Unidos) e periféricas (como o Brasil), na qual as estruturas subdesenvolvidas da periferia condicionavam seu comportamento. Recomendava-se a industrialização por substituição de importações (substituindo bens de consumo que eram importados dos países industrializados) e o monitoramento do fluxo de capitais externos. Isto de modo a evitar o estrangulamento externo (dificuldade de importação de bens de capitais) e a vulnerabilidade externa frente a crises cambiais (Garcia \& Goldbaum, 2001). 


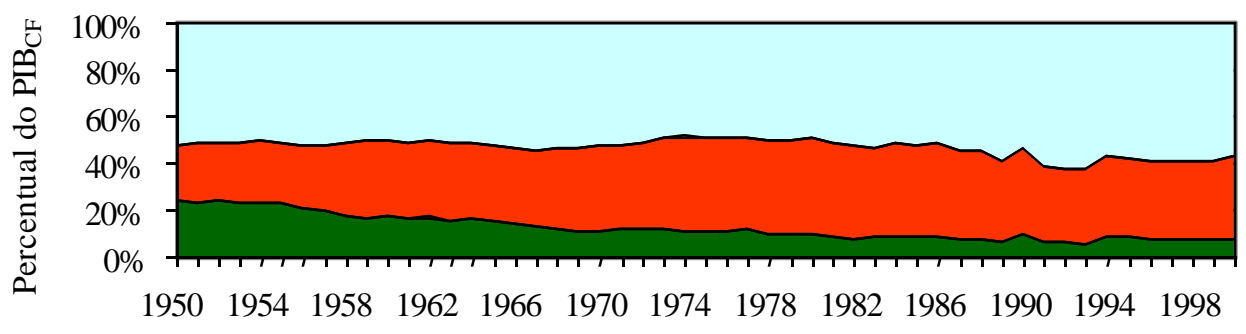

$\square$ Agricultura $\square$ Indústria $\square$ Serviços

Figura 7 - Brasil: evolução da participação percentual dos setores agricultura, indústria e serviços no PIB $_{\mathrm{CF}}, 1950$ a 2000.

Fonte: Anuário Estatístico do Brasil e FGV (2002)

Ao lado da preocupação com o processo de industrialização substitutiva, havia a preocupação com a evolução do processo inflacionário. $\mathrm{O}$ forte crescimento da inflação no início dos anos 60 (Figura 8), implicou na necessidade da montagem de uma estratégia para o seu combate. Na ótica estruturalista, a inelasticidade da oferta agrícola implicava em aumentos de preços, que elevavam o custo de vida do trabalhador. Este, por sua vez, pressionava por salários mais elevados que, em conjunto com o aumento dos preços das matérias primas de origem agrícola, afetavam os custos industriais. $\mathrm{O}$ mecanismo de mark up permitiu a elevação dos preços das industrias oligopolizadas, e, consequentemente, da inflação (Barros, 1993).

A inelasticidade dos preços agrícolas era atribuída à estrutura agrária, caracterizada por latifúndios (auto-suficientes, que exportavam o excedente produzido) e 
minifúndios (com produção apenas para subsistência) ${ }^{26}$. Paralelamente a esta discussão, observa-se, no Brasil, que a forte participação do setor agrícola na composição dos preços dos demais setores permitia que uma deterioração dos termos de troca contra a agricultura fosse efetiva no combate à inflação (Sayad, 1979).

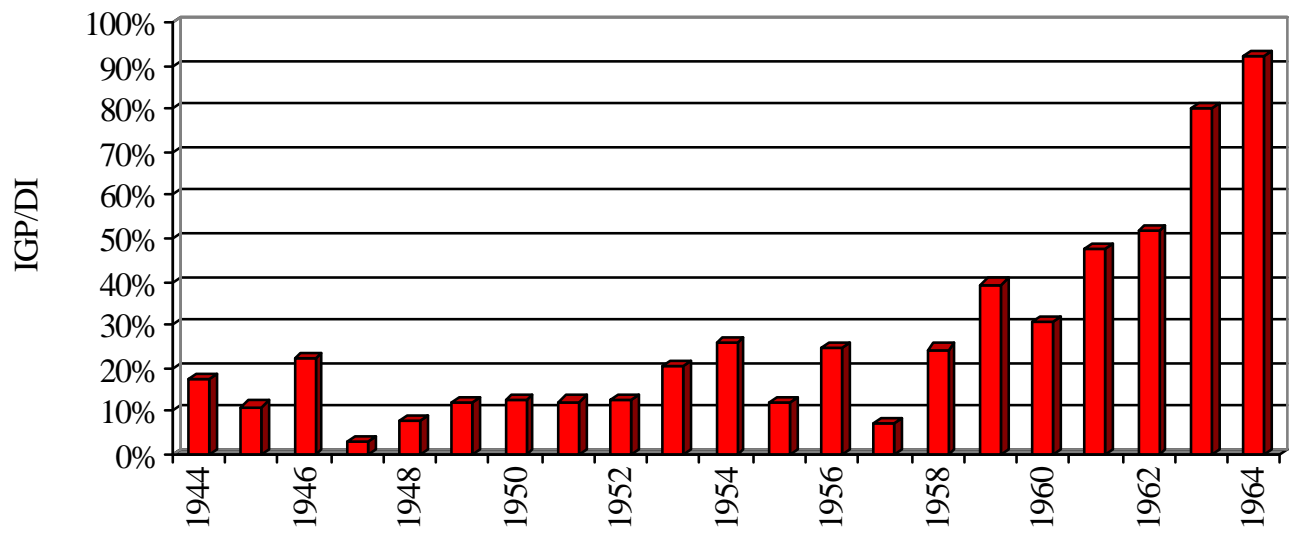

Figura 8 - Brasil: variação anual do IGP/DI no período de 1944 a 1964, em percentual.

Fonte: FGV (2002)

A estratégia de política agrícola adotada nos anos 60 teve como objetivo a elevação da oferta de produtos. Assim, buscou-se a produção de bens que apresentassem demanda no mercado internacional (para que houvesse o crescimento da agricultura brasileira no mercado externo); a modernização da agricultura com uso de insumos que passavam a ser produzidos internamente ${ }^{27}$; e, a expansão da fronteira

\footnotetext{
${ }^{26}$ Esta visão estruturalista, que implicava em propostas de reforma agrária, não foi unanime, tendo sido produzidos, também, trabalhos contestando a inelasticidade da oferta agricultura brasileira. Destaca-se, neste aspecto, o trabalho:

PASTORE, A. A resposta da produção agrícola a preços no Brasil. São Paulo: USP, FEA, 1968.

Estudos, como o de Brandt (1966), verificavam a resposta positiva dos produtores agrícolas às variações em preços reais dos produtos.

${ }^{27}$ Somente na indústria de fertilizantes, entre 1967 e 1973 foram instaladas 20 novas empresas (Kageyama et al., 1990).
} 
agrícola com aumento da área plantada, alcançando as regiões Centro-Oeste e Norte do País (Barros, 1993).

Um importante instrumento para viabilizar esta estratégia, fundamental na motivação para que o agricultor aderisse ao processo de modernização, foi a política de crédito rural abundante e barato (isto é, com taxas de juros inferiores às praticadas no mercado financeiro não rural) para o tomador. Para tanto, o crédito rural foi efetivamente institucionalizado no Brasil em 1965, com a Lei $\mathrm{n}^{\mathrm{o}} 4829^{28}$, juntamente com a reforma do sistema financeiro brasileiro ${ }^{29}$. Como as taxas de juros no crédito rural eram baixas, o endividamento era atrativo aos agricultores $^{30}$ (Carvalho \& Barcelos, 2002).

Observou-se, então, uma alta demanda pelo crédito barato ${ }^{31}$. Isto implicou na necessidade ${ }^{32}$ de se utilizar fontes de financiamento estatal, pois não havia atratividade para os financiamentos privados (Araujo, 1983). Ressalte-se que este desinteresse do setor privado implicou na aplicação compulsória de recursos, a chamada exigibilidade das aplicações bancárias. No entanto, os recursos originados desta exigibilidade ficaram aquém da demanda, implicando na necessidade do Governo participar significativamente da oferta de recursos para atender aos objetivos de sua

\footnotetext{
${ }^{28}$ Esta Lei definiu, entre outros assuntos, que as aplicações em crédito rural deveriam apresentar taxas de juros preferenciais, inferiores às praticadas no mercado.

${ }^{29}$ Não obstante a inserção do crédito rural neste cenário de políticas voltadas ao controle da inflação, a política de crédito rural funcionou também como um mecanismo de compensação ao setor agrícola dentro das políticas econômicas do país, estabelecidas basicamente para estimular a produção industrial e controlar a inflação (Araujo, 1983). Este aspecto compensatório é especialmente notado com relação à sobrevalorização do câmbio necessária ao processo de substituição de importações (Dias, 1989).

${ }^{30}$ Ou seja, nível de endividamento ótimo maior que zero.

${ }^{31}$ A coexistência de linhas de crédito a juros favorecidos com linhas de crédito a juros reais positivos estimulou os empresários a procurarem os financiamentos diferenciados (em muitos casos, subsidiados) para suas opções de investimento (Araujo, 1983).

${ }^{32}$ A necessidade de atender a demanda reside, entre outras razões, na importância do crédito para o desenvolvimento agrícola (uma vez que pode favorecer a adoção de novas tecnologias), controle da inflação (diretamente pela maior oferta de alimentos e indiretamente atendendo à demanda dos trabalhadores, pois, se assim não o fizesse, implicaria em aumento dos preços dos alimentos, pressionando salários e, consequentemente, os custos das empresas) e compensação aos agricultores pelos efeitos de políticas direcionadas a outros setores da economia.
} 
política macroeconômica. A Figura 9 ilustra a forte participação dos bancos estatais na oferta de crédito rural. Destaca-se a forte presença dos bancos oficiais federais ${ }^{33}$, que tiveram uma participação média de $67 \%$ no período, atingido o pico de $84 \%$ no ano de 1988.

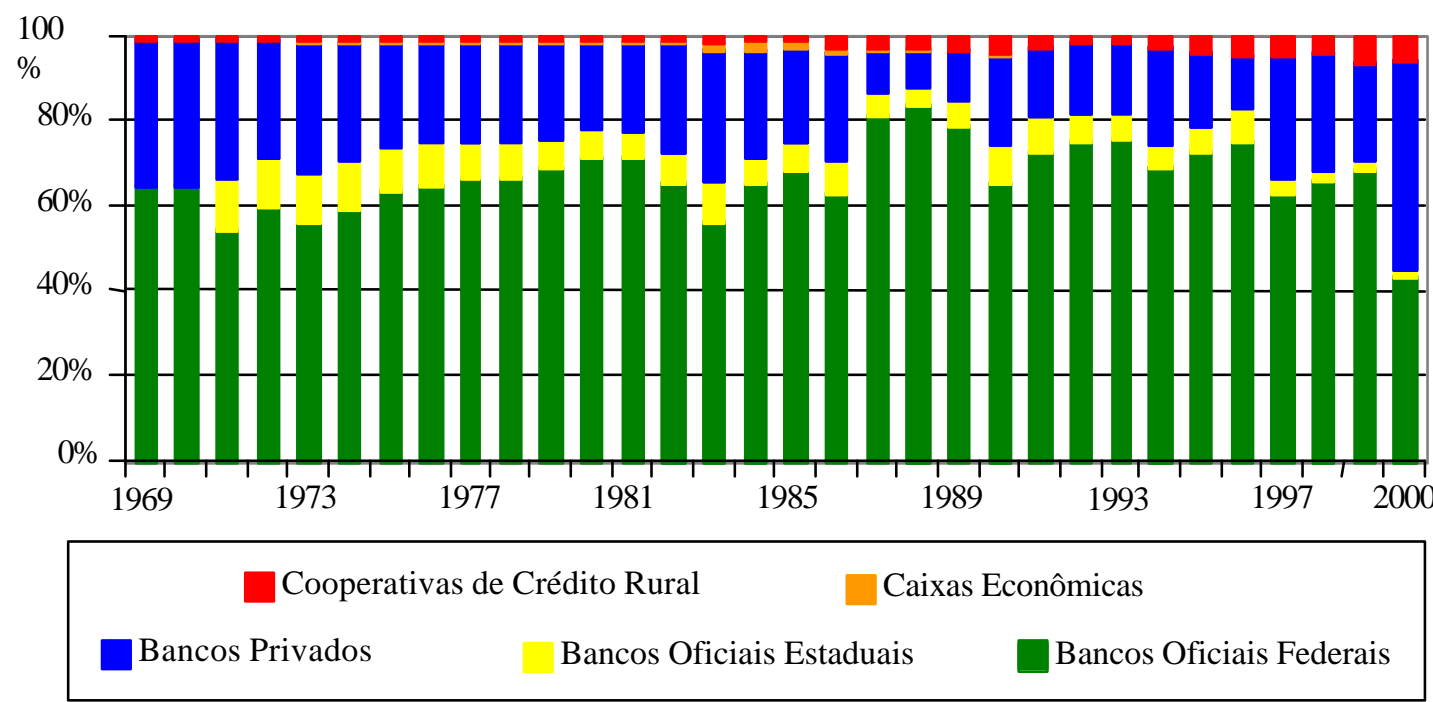

Figura 9 - Brasil: participação percentual de diferentes instituições financeiras no volume anual de crédito rural concedido, de 1969 a 2000.

Fonte: Gasques \& Conceição (2001) e BACEN (2001)

O controle das taxas de juros do crédito rural, mantidos em níveis inferiores ao da inflação (a correção monetária plena só ocorreu a partir de 1987), implicou em forte subsídio. O subsídio concedido através do crédito rural foi estimado como representando, em média, $12 \%$ do produto agropecuário na década de 70 , atingindo 22\% em 1980 (Araujo et al., 2001). As autoridades subestimaram

\footnotetext{
${ }^{33} \mathrm{Em}$ termos práticos, os bancos oficiais federais, no que se refere à oferta de crédito rural, podem ser entendidos como Banco do Brasil (Shirota, 1988).
} 
grandemente a inflação futura quando da prefixação da correção monetária ${ }^{34}$ (Shirota, 1988; Barros \& Araujo, 1995). A Figura 10 ilustra a evolução da taxa real de juros no crédito rural, na modalidade de custeio.

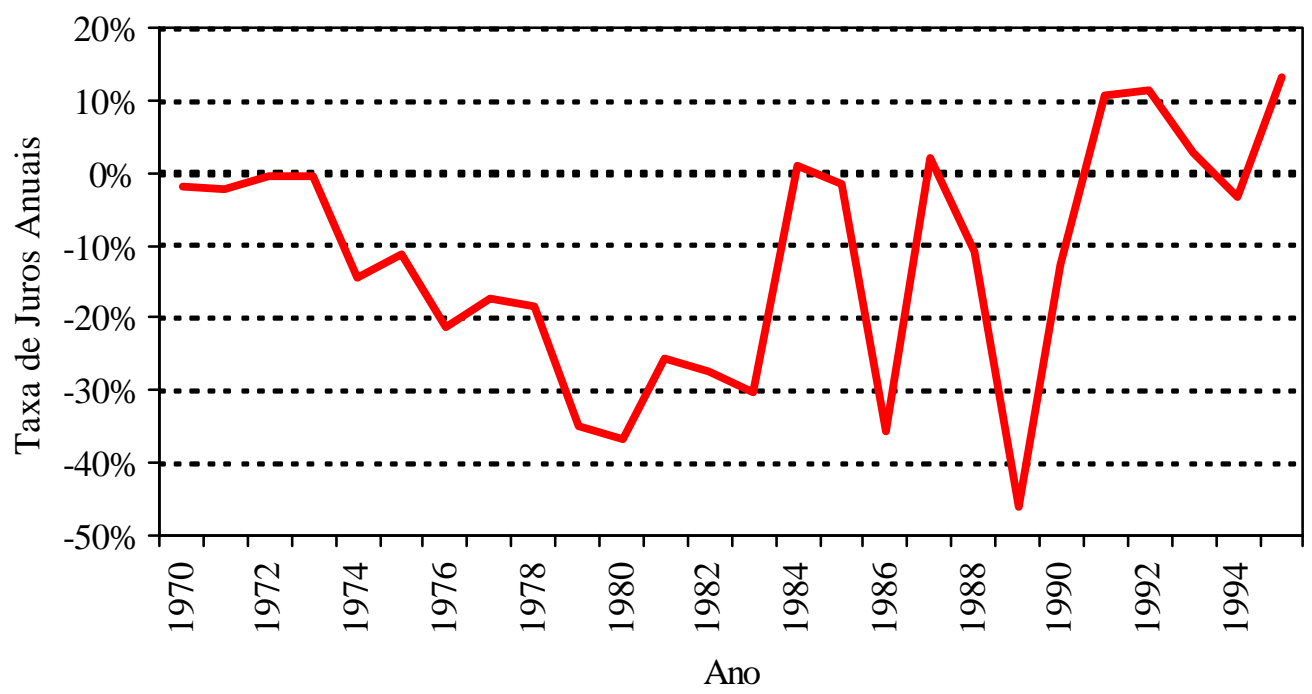

Figura 10 - Brasil: evolução da taxa de juros real em operações de crédito rural para custeio, 1970 a 1995 , em \% a.a.

Fonte: Shirota (1988) e Franca (1996)

Adicionalmente, ressalte-se que é praticamente impossível saber - antes, durante ou depois de cada evento - qual é o real uso do empréstimo, face a fungibilidade do crédito (que lhe confere a capacidade de ser livremente alocado ou trocado por outros bens). O simples fato de ser concedido a produtores (ou pessoas, física ou jurídicas, ligadas ao setor), ou ser garantido por terras, equipamentos ou produtos agrícolas, não impede que o crédito seja utilizado para outros fins (Kane, 1984). Assim, recursos

\footnotetext{
${ }^{34}$ A instabilidade dos preços, na época, implicou em elevada dificuldade na previsão da taxa de inflação, e, consequentemente, da taxa de subsídio (Shirota, 1988).
} 
baratos podem substituir o uso dos recursos próprios, que passam a ser aplicados em atividades de maior retorno financeiro. Desta forma, com subsídio, chega-se a uma situação em que a agricultura passa a depender fortemente do crédito rural para financiar suas atividades e, cada vez menos, são essas atividades financiadas com recursos próprios dos agricultores (Araujo, 1983).

Deve-se destacar que, como a principal fonte de crédito rural era do setor público, a maior parcela do subsídio foi arcada pelo Governo. O impacto destes subsídios afetaram o Orçamento da União. Isto porque quando o tomador de crédito rural liquidava sua dívida subsidiada, o valor das amortizações e juros pagos eram insuficientes para manter o mesmo nível de empréstimos rurais. A diferença, para manter o saldo rural em termos constantes, representavam a pressão expansionista sobre a base monetária (Tabela 6). Assim, os subsídios de um ano qualquer representavam pressão sobre a base do ano seguinte ${ }^{35}$ (Sayad, 1982).

Através da Resolução 69 do Banco Central do Brasil, de 22/09/67, foi fixado um piso de obrigatoriedade de empréstimo à agricultura sobre os depósitos à vista do sistema bancário. Com o passar do tempo, a retomada do processo inflacionário implicou em redução no volume de recursos canalizados por esse mecanismo. Isto em função da redução ocorrida nos depósitos bancários, que é base de cálculo para determinação de recursos. Buscando substituir o volume perdido desta importante fonte de recursos, foram criados diversos fundos e programas específicos para atender à demanda de crédito rural.

\footnotetext{
35 As variações na base monetária resultam da influência de diversos fatores, além da pressão expansionista do subsídio, como, por exemplo, pela elevação da inflação ou pelo crescimento das reservas.
} 
Tabela 6. Brasil: estimativa das parcelas dos subsídios do programa de crédito rural financiadas pela dívida pública, expansão de base monetária e por depositantes do sistema bancário, de 1971 a 1981 (percentagens).

\begin{tabular}{cccc}
\hline & \multicolumn{3}{c}{ Parcela financiada por (pela) } \\
\cline { 2 - 4 } Ano & Dívida Pública & Depositantes & Base Monetária \\
\hline 1971 & 0,0 & 83,2 & 16,8 \\
1972 & 31,6 & 62,5 & 5,9 \\
1973 & 37,1 & 58,0 & 4,9 \\
1974 & 4,8 & 91,8 & 3,4 \\
1975 & 15,7 & 79,3 & 5,0 \\
1976 & 11,0 & 82,6 & 6,3 \\
1977 & 18,3 & 72,2 & 9,5 \\
1978 & 21,3 & 67,7 & 11,0 \\
1979 & 20,1 & 64,4 & 15,5 \\
1980 & 17,2 & 61,8 & 21,0 \\
1981 & 25,5 & 62,0 & 12,5 \\
\hline
\end{tabular}

Fonte: Sayad (1982)

Observa-se pela Figura 11 a elevação da participação do Banco do Brasil. Os depósitos a vista dos bancos comerciais decresciam, no período analisado, à medida em que a taxa de inflação aumentava. Como o volume dos depósitos a vista do Banco do Brasil também se reduzia, depreende-se que parcela crescente do crédito rural estava sendo financiada com recursos oriundos do Banco Central, via conta movimento do 
Banco do Brasil (Barros \& Araujo, 1995). Essa conta tinha por objetivo cobrir, diariamente, a diferença entre a captação não monetária e os desembolsos realizados pelo banco. Entre os desembolsos estavam os empréstimos do Banco do Brasil aos agricultores e os refinanciamentos efetuados pelo Banco Central, cabendo a responsabilidade de execução financeira ao Tesouro Nacional (Araujo et al., 2001).

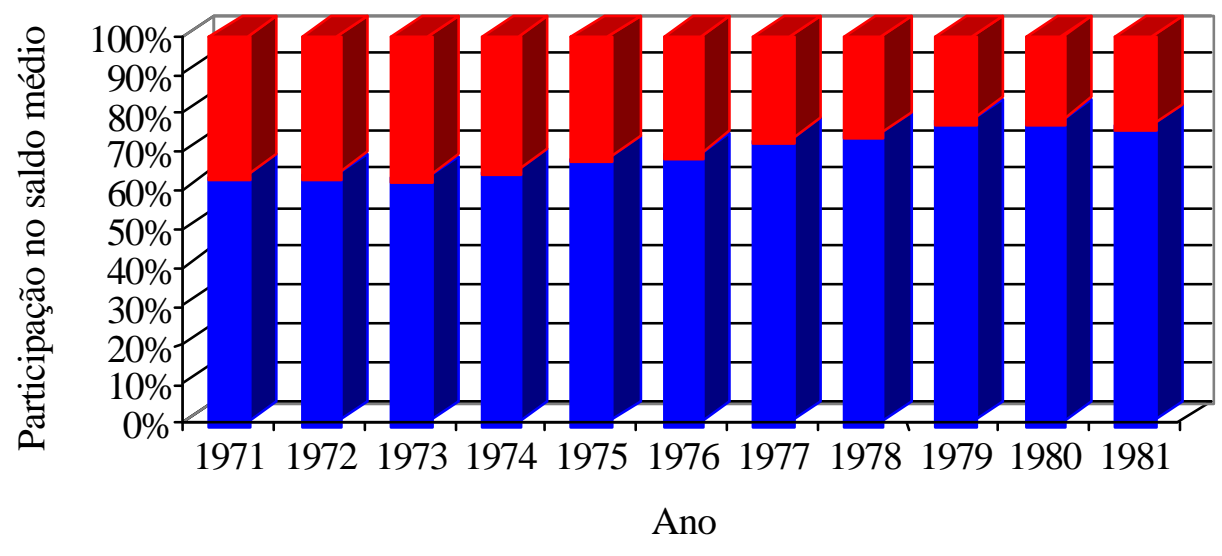

Banco do Brasil

Bancos Comerciais

Figura 11 - Brasil: evolução da participação no saldo médio do crédito rural, por tipo de agente financeiro, no período de 1971 a 1981.

Fonte: Sayad (1982)

Os choques dos aumentos de preços do petróleo nos anos 70, aliados a fortes alterações no mercado financeiro, como a elevação das taxas de juros (internos e externos) e de inflação, provocaram forte crise fiscal no Brasil. Durante a década de 70, caracterizada pelas políticas macroeconômicas expansionistas dos Estados Unidos, foram construídos os desequilíbrios nos países emergentes que culminaram com a crise da dívida, iniciada no final de 1982 (Pastore \& Pinotti, 2000). Houve forte redução do financiamento externo. Estima-se que o montante de novos capitais privados destinados 
aos países em desenvolvimento declinou de um pouco mais de 64 bilhões de dólares em 1981 para 36 bilhões de dólares em 1984 (Vellutini, 1991). A capacidade de poupança do setor público se exauriu e a inflação atingiu níveis politicamente insustentáveis (Barros \& Araujo, 1995). A expansão da produção agrícola para exportação recebeu atenção especial como instrumento de melhoria da balança comercial (Figura 12), fortemente afetada pela crise do petróleo ${ }^{36}$ (Baer, 1996). Neste aspecto, destaca-se o II PND (Plano Nacional de Desenvolvimento), de 1975 a 1979, que, na busca da autosuficiência nacional, teve como principais objetivos substituir as importações ${ }^{37}$, elevar as exportações e ampliar o mercado consumidor interno.

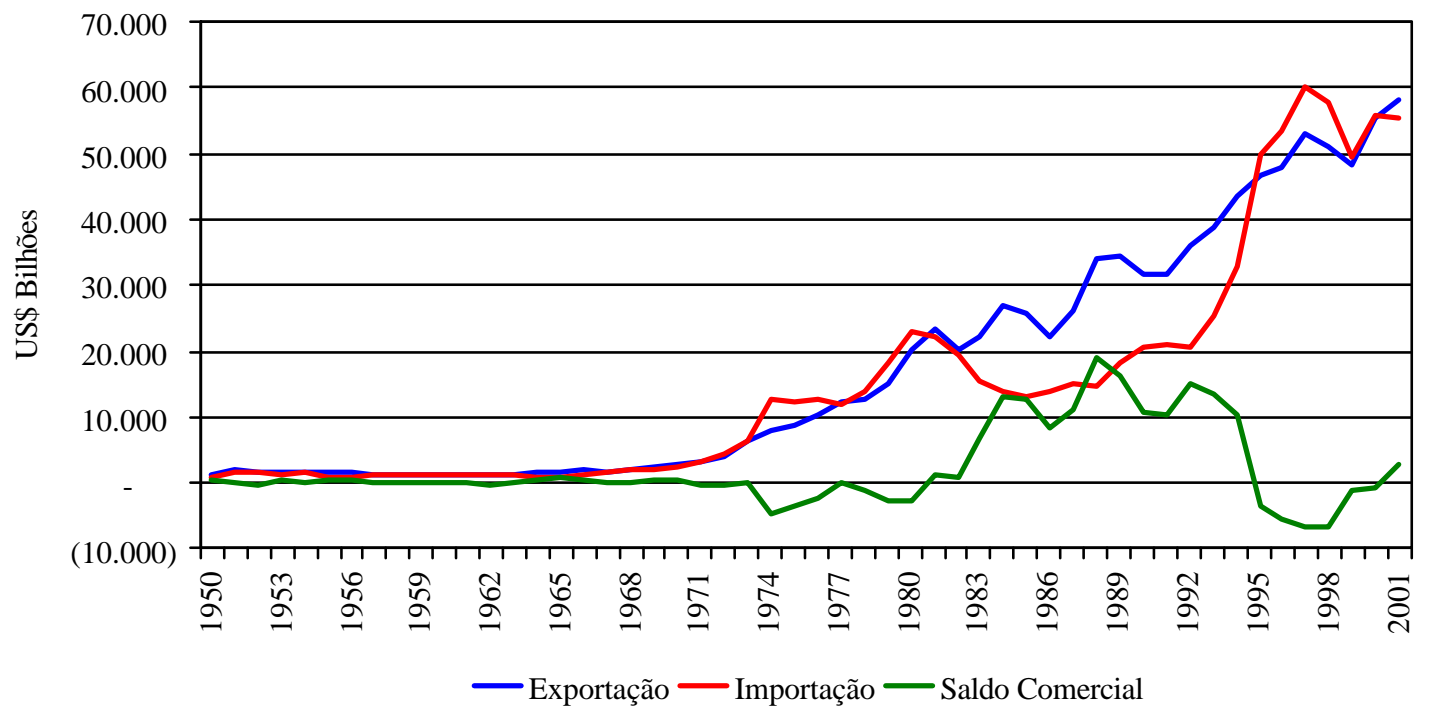

Figura 12 - Brasil: evolução da balança comercial, 1950 a 2001, em bilhões de dólares.

Fonte: FGV (2002)

${ }^{36}$ O volume de importações do Brasil em 1972 foi de US\$ 4.235 bilhões. Em 1974, após o primeiro choque nos preços do petróleo, as importações atingiram US\$12.641 bilhões. Em 1972 o Brasil apresentou superávit de US\$ 244 milhões e, em 1974, déficit de US\$ 4.690 milhões na balança comercial.

${ }^{37}$ Somente na indústria de fertilizantes, entre 1974 e 1983 foram instaladas 68 novas plantas, mais da metade para a produção de fertilizantes simples fosfatados (Kageyama et al., 1990). 
Neste novo contexto, o chamado problema agrícola substitui o problema agrário como foco das políticas macroeconômicas. O subsetor voltado para o mercado externo se desenvolveria beneficiando-se das novas tecnologias, cujo uso era viabilizado pelo crédito rural (Barros, 1993).

A literatura apresenta a hipótese de que o crédito rural teria sido um importante determinante adoção de novas tecnologias e no crescimento da produção agrícola [Conceição et al. (1998); Sperl \& Araujo (1995); Vicente (1999); Kageyama et al. (1990)]. A correlação positiva entre a produção agrícola e o volume de crédito rural no Brasil (Figura 13) é explicada, por estes autores, em função da disponibilidade de crédito para compra de máquinas e insumos modernos ${ }^{38}$. Ressalve-se que não há uma comprovação econométrica para esta hipótese, e, citando Araujo (1983), "que mesmo revelando sensíveis acréscimos de certos insumos associados a ganhos de produtividade, a principal variável a explicar o crescimento da produção agrícola continuou sendo a intensificação no uso dos fatores tradicionais". Adicionalmente, deve ser ressaltado que apenas $15 \%$ dos estabelecimentos rurais existentes no país obtiveram algum tipo de financiamento de fontes institucionais ou não, durante a década de 1970 (Araujo, 1983).

Desta forma, durante a década de 70, criou-se expectativa a respeito de uma possível concentração do crédito rural para os produtos exportáveis em detrimento do financiamento da produção de alimentos. Contrariando de certa forma esta expectativa, os produtos básicos de mercado interno tiveram ligeiro aumento de participação no crédito total de custeio, mas que foi o suficiente para, já a partir de 1975, praticamente eliminar a desigualdade na distribuição de crédito em relação ao valor da produção entre os grupos de produtos agrícolas exportáveis e os alimentos simples (Hoffmann \& Kageyama, 1987). Dentre as explicações para este fato, os autores do estudo destacam:

\footnotetext{
${ }^{38} \mathrm{O}$ fato da assistência técnica ter sido obrigatória aos mutuários do crédito rural, favorecendo o contato entre técnicos e produtores, teria, também, estimulado o uso de insumos modernos.
} 
a) do lado da oferta, o aumento da participação de empresas capitalistas - com maior poder de acesso ao crédito bancário - na produção de culturas tradicionalmente a cargo de empresas familiares (como, por exemplo, o caso do arroz na região Centro-Oeste); e,

b) do lado da demanda, a intensificação do consumo interno (principalmente nas áreas urbanas) de alimentos industrializados, por efeitos renda e substituição, fez com que uma parte crescente da produção agrícola que era classificada como exportável ${ }^{39}$ passasse a ser efetivamente consumida dentro do país.

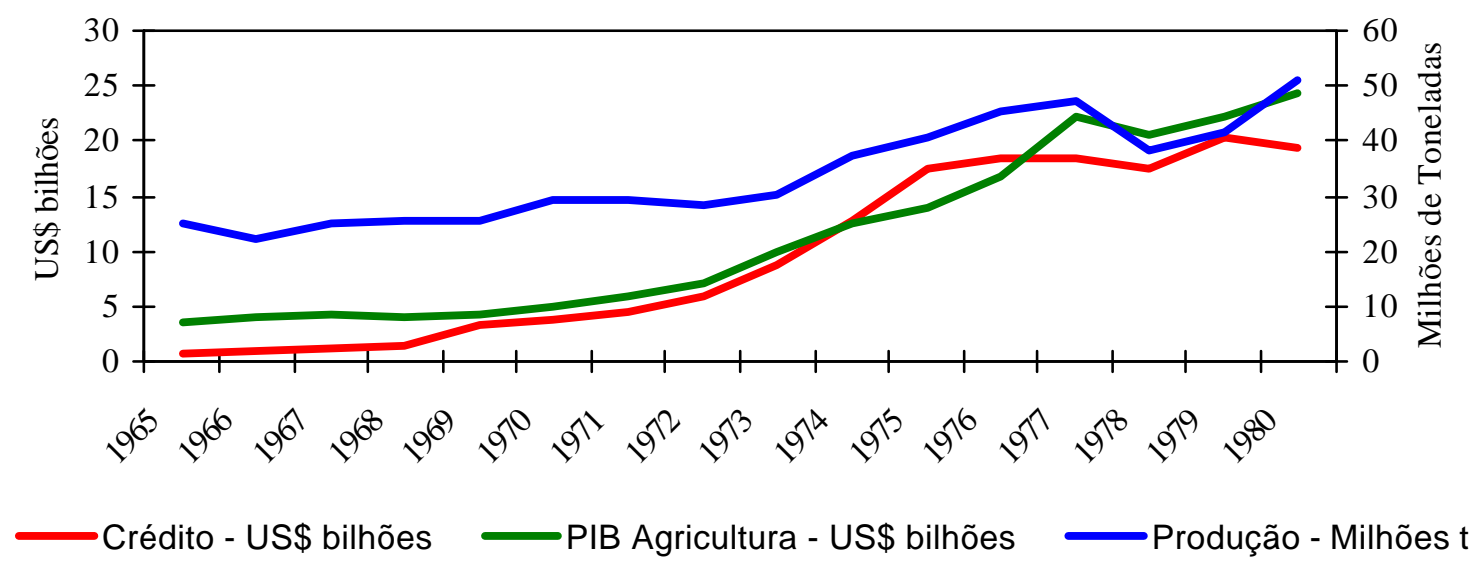

Figura 13 - Brasil: evolução da produção de grãos, em milhões de toneladas, e do volume de crédito rural e do PIB-Agricultura, em bilhões de dólares, período de 1965 a 1980.

Fonte: Brasil (2002)

${ }^{39}$ Algodão, amendoim, cacau, café, cana-de-açúcar e soja (Hoffmann \& Kageyama, 1987). 
Com a redução das fontes de recursos, a partir do final dos anos 70 , diminuiu a oferta de crédito rural. No período de 1980 até 1999 o volume de crédito concedido a produtores e cooperativas reduziu-se de mais de $\mathrm{R} \$ 50$ bilhões anuais para menos de $\mathrm{R} \$ 10$ bilhões em meados dos anos 90 (Figura 3).

A partir do Plano Cruzado (fevereiro de 1986), o governo passou a buscar fontes não inflacionárias de recursos para o crédito rural ${ }^{40}$. Em 1986 foi criada a caderneta de poupança rural e a Constituição de 1988 criou os chamados Fundos Constitucionais de Financiamento - FNO, FNE e FNCO - gerados pelo percentual de 3\% da arrecadação do IPI e do IR. A Lei 8023 de 1990, que ainda não foi regulamentada, prevê que os recursos arrecadados com o imposto de renda deverão ser canalizados para um fundo fiscal de financiamento da agricultura. Na busca de uma elevação na oferta de recursos, deve-se destacar, também, a participação do Banco Nacional de Desenvolvimento Econômico e Social (BNDES) no financiamento de investimentos, a partir de 1991, com operações de FINAME-Rural e do Programa de Operações Conjuntas - POC; e, a partir de 1996, com operações com recursos do Fundo de Amparo ao Trabalhador - FAT, para financiar investimentos do Programa de Fortalecimento da Agricultura Familiar ${ }^{41}$ (Araujo et al., 2001).

${ }^{40}$ À medida em que foram adotadas fontes não inflacionários de recursos para o crédito rural, a vinculação desta política à evolução da inflação brasileira mostrou-se bem menos marcante (Barros \& Araujo, 1995).

41 Além dos citados (FINAME, POC e PRONAF), o BNDES possui ainda os seguintes programas voltados ao setor agropecuário: Programa de Fruticultura para a Região Norte-noroeste Fluminense; Modernização da Frota de Tratores Agrícolas e Implementos Associados e Colheitadeiras MODERFROTA; Programa Especial de Financiamento Agrícola; Programa de Incentivo à Construção e Modernização de Unidades Armazenadoras em Propriedades Rurais - PROAZEM; Programa de Apoio ao Desenvolvimento da Aqüicultura; Programa de Desenvolvimento Sustentado da Floricultura PRODEFLOR; Programa de Incentivo à Mecanização, ao Resfriamento e ao Transporte Granelizado da Produção de Leite - PROLEITE; Programa de Desenvolvimento da Ovinocaprinocultura PRODECAP; Programa de Desenvolvimento da Apicultura - PRODAMEL; Programa de Desenvolvimento da Cajucultura - PROCAJU; Programa de Apoio à Fruticultura - PROFRUTA; Programa de Incentivo ao Uso de Corretivos de Solos - PROSOLO; Programa Nacional de Recuperação de Pastagens Degradadas - PROPASTO; Programa de Apoio ao Desenvolvimento da Vitivinicultura PRODEVINHO; Programa de Sistematização de Várzeas - SISVARZEA; Programa de Apoio ao Desenvolvimento da Cacauicultura - PROCACAU; Programa de Plantio Comercial de Florestas PROPFLORA; Programa de Desenvolvimento Cooperativo para Agregação de Valor à Produção Agropecuária - PRODECOOP; e, Programa de Apoio à Agricultura Irrigada - PROIRRIGA (BNDES, 2002). 
Um fato que merece destaque foi o decréscimo da participação dos recursos do Tesouro Nacional entre as fontes de crédito concedido à agricultura (Figura 14), que passou de 19,7\% em 1995 para 1,88\% em 1998 (Araujo, 2000a).

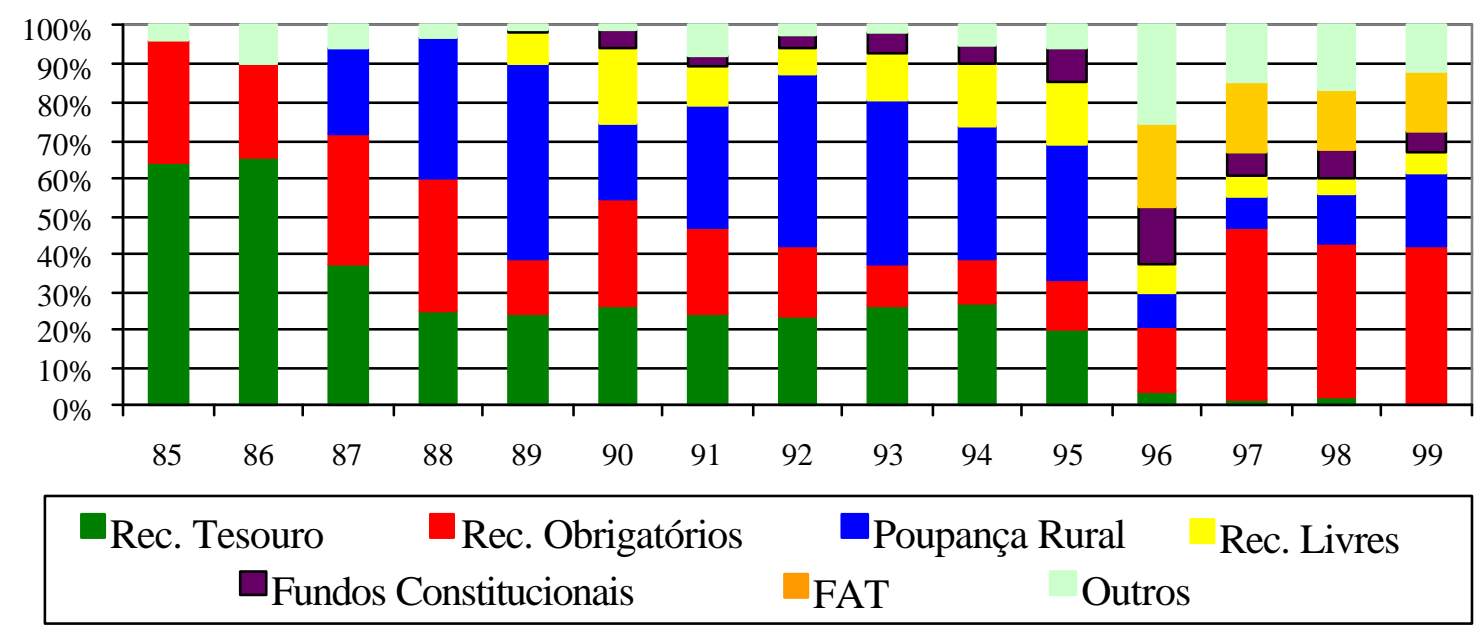

Figura 14 - Brasil: evolução da participação relativa das principais fontes de recursos nos financiamentos concedidos a produtores e cooperativas, em percentual, de 1985 a 1999.

Fonte: Gasques \& Conceição (2001)

\subsection{Situação atual do crédito rural no Brasil}

Fortes mudanças no cenário macroeconômico ocorreram nos anos 90, em especial após 1994 (Plano Real). Estas mudanças afetaram o sistema financeiro voltado 
para agricultura, exigindo maior esforço de captação de recursos junto ao público e maior racionalidade no desempenho de suas funções de aplicação e recuperação de recursos creditícios em função das especificidades da agricultura (Barros \& Araujo, 1995). Destaca-se que o crédito rural é uma atividade excessivamente normatizada, que apresenta demanda sazonal, envolvendo grande número de profissionais e uma tecnologia diferenciada, o que influencia o custo total de transação das instituições financeiras (Guidetti, 1998). Adicionalmente, os problemas do atual sistema de crédito (como o elevado patamar das taxas de juros) têm dificultado o desenvolvimento de novos mecanismos de financiamento (Gasques \& Conceição, 2000).

Quatro fatores têm sido importantes para a diminuição da oferta de crédito rural nos últimos anos (Gasques \& Conceição, 2001):

a) redução dos recursos do Banco do Brasil e de outros bancos (Tabela 7), destacando-se a forte queda nas fontes de recursos referentes aos Recursos Livres $(94,8 \%)$ e aos Recursos Obrigatórios (34,9\%);

b) redução nos recursos para equalizações específicas para agricultura ${ }^{42}$ (isto é, exclusive o PROEX), resultado da menor demanda dos bancos (Tabela 8);

c) aumento dos custos para os tomadores de recursos externos pela "63 Rural" ${ }^{43}$. Os encargos financeiros para os usuários, superiores a 20\%, e a cláusula de correção cambial reduziram a atratividade dessa fonte desde a desvalorização cambial realizada pelo governo em janeiro de 1999; e,

\footnotetext{
42 Dispêndios realizados pelo governo à conta do Tesouro Nacional para execução de políticas e programas da agricultura.

${ }^{43}$ Resolução no 2.822 de 1998.
} 
d) mudanças das estratégias bancárias ${ }^{44}$, sendo que o elevado endividamento dos agricultores tem contribuído para ocorrência dessas mudanças (Araujo, 2000b). O crescimento da inadimplência nos anos $90^{45}$, que resultou no processo de securitização ${ }^{46}$, tornou os bancos mais seletivos. A entrada de bancos estrangeiros no segmento de varejo e a adequação do sistema bancário ao Acordo da Basiléia levaram à adoção de novos e mais rigorosos procedimentos para análise de crédito (Faveret Filho et al., 2000).

Esta mudança de cenário não ocorre exclusivamente no Brasil, tratandose de um fenômeno mundial. A literatura ${ }^{47}$, citada por Gasques \& Conceição (2001), mostra que o modelo tradicional de crédito apresentava problemas, tais como: (i) as intervenções do Estado não resultavam em elevação de enda e redução de pobreza; (ii) não considerava que comunidades rurais pobres poupavam; (iii) ignorou pequenas empresas rurais não-agrícolas. Mundialmente, alterou-se o paradigma no financiamento rural. As diversas economias (inclusive o Brasil) têm buscado, na medida de suas possibilidades, adaptar seus programas de crédito a esta alteração de paradigma. A Tabela 9 apresenta as principais características do velho e do novo paradigma de financiamento rural.

${ }^{44}$ Com o objetivo de reduzir o risco e o custo dos empréstimos bancários, os bancos, por meio de contratos formais ou de orientações informais, têm realizado parcerias com tradings e indústrias, tanto de insumos quanto de bens de capital (Faveret Filho et al., 2000; Gasques \& Conceição, 2001). Neste tipo de operação, o banco fornece recursos a seus parceiros para que estes financiem os agricultores, reduzindo, assim, o risco direto do banco com o setor.

${ }^{45}$ A inadimplência da carteira rural do Banco do Brasil atingiu 21\% (crédito em atraso e liquidação sobre o total de crédito) em 1998. O Banco do Brasil respondia por 56\% do saldo aplicado em crédito rural no Brasil em 1998 (Faveret Filho et al., 2000).

${ }^{46}$ Lei 9138 de 29/11/95.

47 YARON J.; BENJAMIN JR, Mc.P.; PIPREK, G.L. Financiamiento rural: problemas, diseño y prácticas optimas. s.l.: Banco Mundial, 1999. (Série de Monografias y Estudios sóbre el Desarrolo Social y Ecológicamente Sostenible, 14) 
Tabela 7. Brasil: evolução do volume anual de financiamentos concedidos a produtores e cooperativas em operações de custeio, investimento e comercialização, realizadas pelo Banco do Brasil, por fonte de recursos, de 1997 a 1999, em milhares de Reais de 1999.

\begin{tabular}{lrrr}
\hline \multicolumn{1}{c}{ Fonte de Recursos } & 1997 & 1998 & 1999 \\
\hline Recursos do Tesouro & 181.518 & 200.187 & 7.592 \\
Recursos Obrigatórios & 998.195 & 1.172 .864 & 763.406 \\
Poupança Rural & 963.237 & 1.585 .136 & 2.182 .547 \\
Recursos Livres & 449.171 & 178.582 & 9.314 \\
Fundos Constitucionais & 241.990 & 328.745 & 128.339 \\
FAT (Fundo de Amparo ao Trabalhador) & 1.962 .967 & 1.623 .388 & 1.678 .220 \\
FAE (Fundo Extra-Mercado) & 752.701 & 128.456 & 286 \\
Recursos FUNCAFÉ & 410.163 & 687.011 & 569.196 \\
Recursos do BNDES/FINAME & 323.286 & 205.435 & 272.926 \\
Recursos do INCRA/PROCERA & 58.469 & 139.495 & 34.177 \\
Recursos de Outras Fontes & 34 & 75 & 8.405 \\
Total & 6.341 .730 & 6.249 .373 & 5.654 .408 \\
\hline
\end{tabular}

Fonte: Gasques \& Conceição (2001)

Nota: Deflacionado pelo IGP-DI/FGV. 
Tabela 8. Brasil: evolução das despesas do Tesouro Nacional executadas com equalizações de taxas de juros e preços, 1997 a 1999, em milhares de Reais.

\begin{tabular}{lrrr}
\hline \multicolumn{1}{c}{ Finalidade } & 1997 & 1998 & \multicolumn{1}{c}{1999} \\
\hline Custeio & 229.550 & 288.015 & 158.484 \\
EGF & 240.197 & 22.732 & 9.797 \\
AGF & 925.378 & 220.630 & 227.005 \\
PRONAF & 73.173 & 190.847 & 287.703 \\
Garantia e Sustentação de Preços & - & 202.875 & 64.887 \\
Investimentos & - & - & 13.661 \\
Total & 1.468 .298 & 925.099 & 747.876 \\
\hline
\end{tabular}

Fonte: Gasques \& Conceição ( 2001)

Ao Estado, neste novo cenário, cabe dedicar-se ao ambiente institucional - estabilidade macroeconômica, eliminação de políticas que privilegiam comunidades urbanas em detrimento das rurais e o fortalecimento do mercado financeiro (Gasques \& Conceição (2001). Com relação a este último item, o apoio governamental é vital em dois aspectos: (i) no fortalecimento do sistema de supervisão e na redução da ineficiência do Judiciário, que permitiria uma execução de contratos menos onerosa e mais rápida; e, (ii) na implantação de sistemas de informação ${ }^{48}$ (Meyer \& Nagarajan, 2000, p.148).

${ }^{48}$ Centrais de risco, que permitissem o conhecimento do histórico de crédito dos clientes (informações positivas e negativas) reduziriam o custo da informação para todas instituições. 
Tabela 9. Principais características do velho e do novo paradigma de financiamento rural.

\begin{tabular}{|c|c|c|}
\hline & $\begin{array}{l}\text { Velho Paradigma } \\
\text { (crédito direcionado) }\end{array}$ & $\begin{array}{l}\text { Novo Paradigma } \\
\text { (mercado financeiro) }\end{array}$ \\
\hline Definição do problema & $\begin{array}{l}\text { Superar segmentações de } \\
\text { mercado }\end{array}$ & $\begin{array}{l}\text { Reduzir riscos e custos de } \\
\text { transação }\end{array}$ \\
\hline Papel dos mercados & Promover nova tecnologia & Intermediar recursos mais \\
\hline financeiros & $\begin{array}{l}\text { Estimular a produção } \\
\text { Implementar planos } \\
\text { Ajudar aos pobres }\end{array}$ & eficientemente \\
\hline Visão sobre os usuários & $\begin{array}{l}\text { Tomadores de crédito são } \\
\text { selecionados segundo metas }\end{array}$ & $\begin{array}{l}\text { Tomadores de crédito são } \\
\text { clientes que escolhem } \\
\text { produtos }\end{array}$ \\
\hline Subsídios & Elevados subsídios & $\begin{array}{l}\text { Subsídios pequenos ou } \\
\text { ausentes }\end{array}$ \\
\hline Fonte dos Fundos & Governo e doações & $\begin{array}{l}\text { Depósitos voluntários, na } \\
\text { maioria dos casos }\end{array}$ \\
\hline Sustentabilidade & Em geral ignorada & $\begin{array}{l}\text { Preocupação sempre } \\
\text { presente }\end{array}$ \\
\hline Avaliação & $\begin{array}{l}\text { Impacto do crédito sobre os } \\
\text { beneficiários }\end{array}$ & $\begin{array}{l}\text { Desempenho das } \\
\text { instituições financeiras }\end{array}$ \\
\hline
\end{tabular}

Fonte: Meyer \& Nagarajan (2000) 


\section{A IMPORTÂNCIA DAS INSTITUIÇÕES FINANCEIRAS PARA O FINANCIAMENTO RURAL}

\subsection{Papel do sistema financeiro}

O sistema financeiro tem, entre outros, dois papeis fundamentais na economia. Primeiro, cria moeda e administra meios de pagamento. Segundo, faz a ligação entre poupadores e investidores, entre tomadores e aqueles que concedem empréstimos (Fry, 1995). Os tomadores são aqueles que se encontram em uma posição de déficit financeiro (isto é, aqueles que desejam gastar, em consumo ou investimento, mais do que sua renda). Em situação inversa, os ofertantes de recursos são aqueles que se encontram em posição de superávit financeiro, isto é, aqueles que desejam gastar menos do que sua renda (Rudge \& Cavalcante, 1996). A intermediação financeira é a atividade de obter recursos dos agentes superavitários e transferi-los para agentes deficitários (Figura 15), proporcionando uma elevação na taxa de investimento da economia $^{49}$ (Guidetti, 1998).

\footnotetext{
${ }^{49} \mathrm{O}$ crédito permite, a um empreendedor, a realização imediata de seus projetos de investimento. Isto porque não precisa esperar o acúmulo de reservas para poder aproveitar as oportunidades de compra ou produção (Salomão \& Santos, 1985). Ao elevar a eficiência na transferência de recursos para os agentes deficitários, há um aumento da capacidade financeira destes, isto é, passam a suportar maior volume de débitos (Braga, 1998).
} 


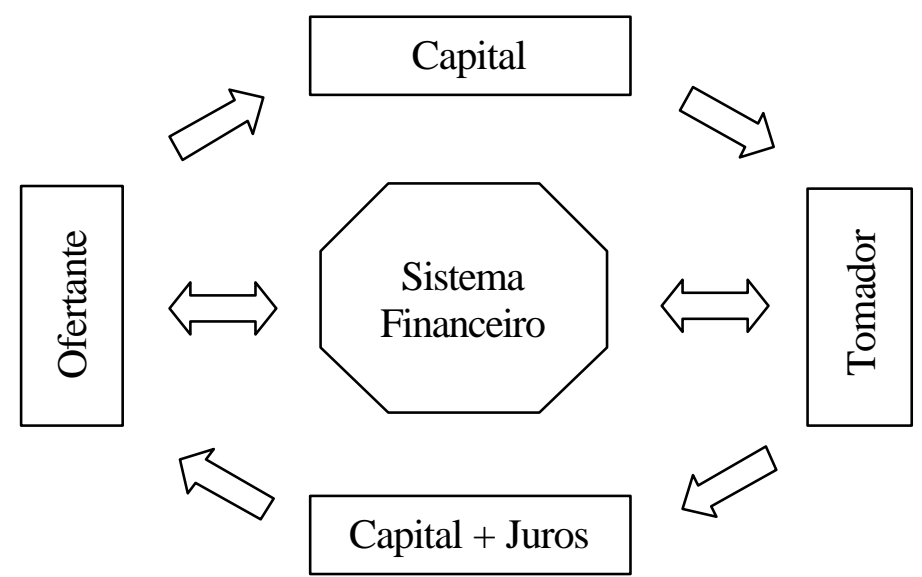

Figura 15 - Fluxo de capitais e o sistema financeiro.

Fonte: Baseado em Rudge \& Cavalcante (1996)

Considerando a distribuição temporal dos eventos, as transações econômicas podem ser divididas em três grupos (Salomão \& Santos, 1985): (i) operações a vista (se a prestação e a contraprestação forem contemporâneas no presente); (ii) operações a termo (se a prestação e a contraprestação forem contemporâneas no futuro); e, (iii) operações de crédito (se a prestação e a contraprestação forem separadas por um intervalo de tempo).

A possibilidade de dissociar uma transação entre uma prestação imediata e a contraprestação em data futura permite a realização de negócios em que o tempo é uma condição essencial.

Em um cenário no qual o mercado fosse competitivo e os custos transacionais (inadimplência inclusive) não existissem, a oferta (S) e a demanda (D) de crédito poderiam ser representadas em um gráfico, onde o volume de crédito concedido (ou tomado) estaria representado no eixo horizontal e a taxa de juros no eixo vertical (Figura 16). Seja $\boldsymbol{j}$ a taxa de juros paga pelos tomadores e $\boldsymbol{i}$ a taxa de retorno gerada pelos créditos aos ofertantes. Se os custos transacionais fossem zero, o equilíbrio do 
mercado seria obtido no ponto A. O volume de crédito seria de $\mathbf{X}_{\mathbf{a}}$ e a taxa de juros seria igual à taxa de retorno, ou seja, $\mathrm{i}_{\mathrm{a}}=\mathrm{j}_{\mathrm{a}}$ :

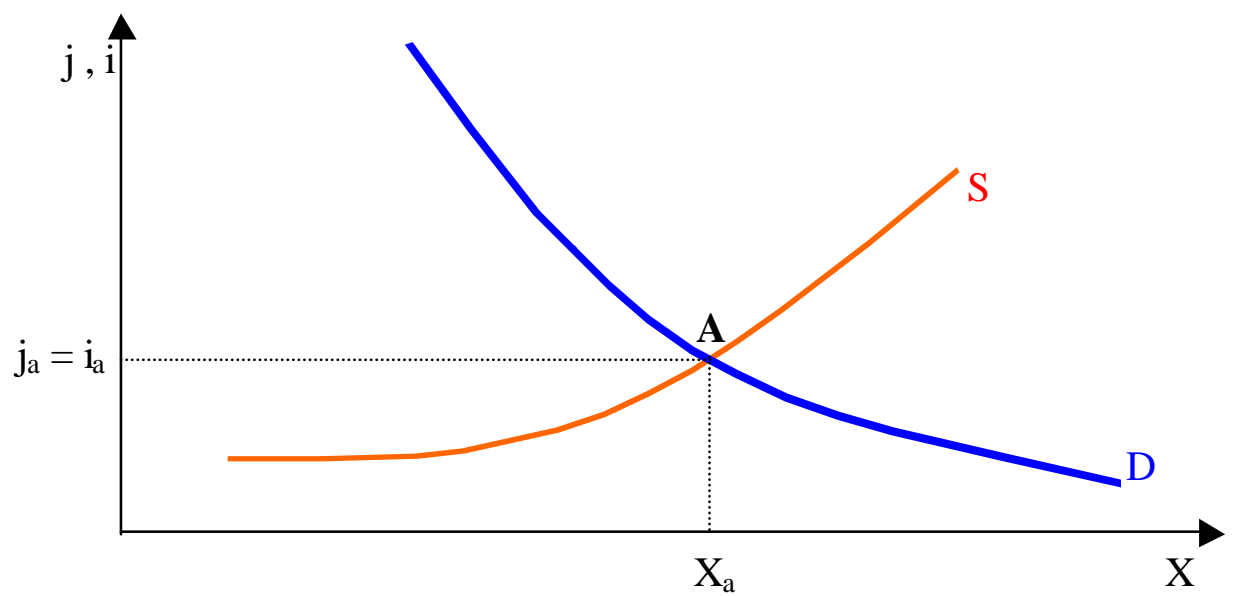

Figura 16-Modelo neoclássico de equilíbrio competitivo entre oferta e demanda de crédito.

O modelo neoclássico de equilíbrio competitivo, que levaria à solução de Pareto $^{50}$, somente ocorre se não houver custos de transação e se os mercados forem perfeitos. Na economia real esta situação não ocorre e diferentes arranjos institucionais o sistema financeiro é uma destas instituições - são criados para facilitar as transações entre diversos agentes econômicos dispersos geograficamente (Shirota, 1996).

Assim, no mundo real, onde os custos de transação não são nulos, a curva de oferta desloca-se para a esquerda, gerando um equilíbrio em T (Figura 17). O deslocamento vertical da curva de oferta de crédito (de $S$ para $S_{t}$ ) equivale ao custo transacional. Nesta nova situação, o volume de crédito será de $X_{(}$(inferior a $X_{a}$ ), sendo

\footnotetext{
${ }^{50}$ Uma situação econômica é eficiente de Pareto se não existir nenhum modo de melhorar a situação de algum grupo de agentes sem piorar a de algum outro grupo (Varian, 1999).
} 
que os tomadores pagarão uma taxa de juros $\mathfrak{j}$, que líquida dos custos transacionais, representará uma taxa de retorno $\mathrm{i}_{\mathrm{t}}$ aos ofertantes do crédito.

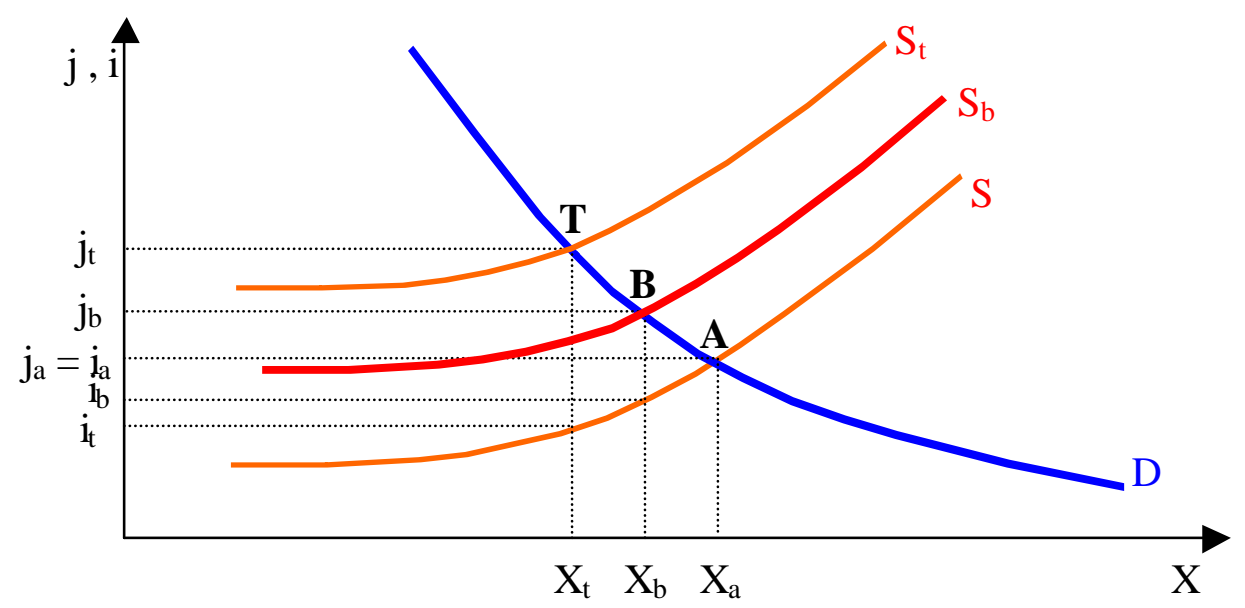

Figura 17 - Oferta e demanda de crédito.

Fonte: Baseado em Guidetti (1998)

Nota: $\mathrm{O}$ subscrito $\underline{\mathrm{b}}$ indica $\mathrm{o}$ resultado da intermediação financeira com redução de custos transacionais.

A redução dos custos transacionais deslocaria a curva de oferta na direção da curva $\mathrm{S}$ original, implicando em maior volume de crédito ofertado a taxas de juros mais baixas.

Em um mercado onde as taxas de juros são fixadas em patamar inferior à taxa de equilíbrio de mercado competitivo, como tem ocorrido nas operações de crédito 
rural no Brasil, surge racionamento de crédito $^{51}$. Ou seja, o mercado não é ajustado através do preço do dinheiro (isto é, da taxa de juros), como seria esperado de acordo com a teoria neoclássica, mas pela redução do volume de crédito ofertado (Lazzarini \& Chaddad, 2000). A redução dos custos de transação implicaria, sob este cenário, em menor racionamento, ou seja, em maior oferta de crédito (Figura 18).

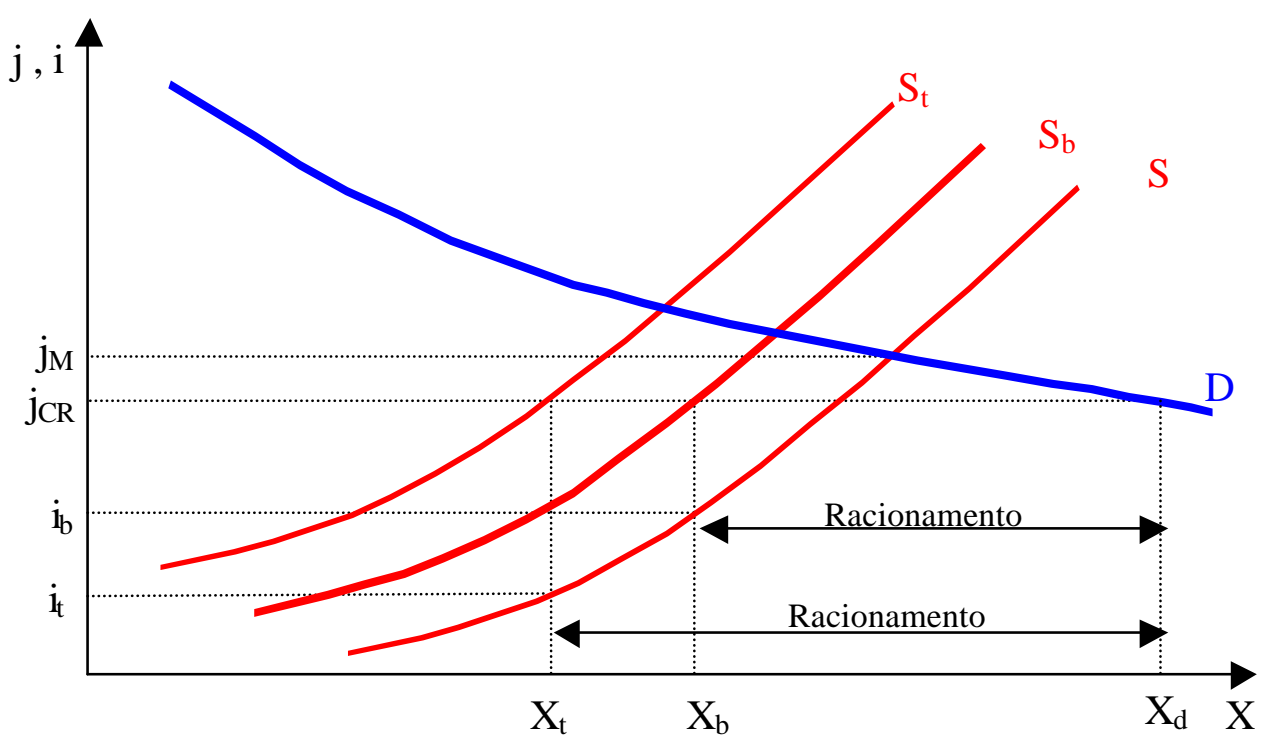

Figura 18 - Impacto da redução dos custos de transação no racionamento de crédito.

Nota: $j_{\mathrm{M}}$ é a taxa de juros de mercado e $j_{\mathrm{CR}}$ é a taxa das operações de crédito rural.

${ }^{51}$ Racionamento de crédito pode ser entendido como uma situação em que, a um determinado nível de juros, parte da demanda não é atendida, embora (estes demandantes) aceitem todas condições necessárias para obtenção do crédito (Braga, 2000). O racionamento pode ser dividido em três grupos: (i) quando os tomadores recebem uma quantidade de recursos menor do que a demandada (racionamento quantitativo); (ii) quando alguns tomadores obtem o empréstimo e outros, com características semelhantes às dos primeiros, não recebem (racionamento qualitativo); e, (iii) auto-racionamento, quando alguns tomadores potenciais não apresentam suas propostas devido aos custos de transação e à pequena probabilidade de obterem os recursos demandados (Araújo, 1996). 
Racionamento de crédito ocorreria mesmo que não houvesse limitação legal da taxa de juros no crédito rural. Isto devido aos custos de transação e à assimetria de informação, conforme discutido a seguir.

Os intermediários financeiros podem reduzir os custos transacionais (Banco Mundial, 1989). Esta é uma das contribuições do sistema financeiro ${ }^{52}$ para o desenvolvimento da economia: ele torna o processo de emprestar e aplicar recursos mais barato e com menor risco (Shirota, 1996). O crédito e os instrumentos financeiros reduzem os custos de transação e os riscos de trocas intertemporais de bens e serviços. Nestes sentido, a existência de crédito aumenta o mercado real, de bens e serviços. O impacto do mercado financeiro no mercado real é similar ao da redução de custos de transportes nas trocas no espaço físico (Bhatt, 1983).

Um dos principais problemas na intermediação financeira é a assimetria de informações, uma relevante fonte de risco de crédito, sendo este definido como a possibilidade do devedor não pagar (Banco Mundial, 1989). Este problema repercute mesmo antes da formalização do contrato $^{53}$, de modo que o equilíbrio no mercado de financiamentos pode caracterizar-se por racionamento de crédito (Stiglitz \& Weiss, 1981). Bancos concedem financiamentos baseados nas taxas de juros e no grau de risco. Quanto maior for a taxa de juros, maior será a taxa de retorno esperada pelo credor. No entanto, a taxa de juros afeta o grau de risco porque pode provocar seleção adversa e afeta a decisão dos tomadores. Diferentes tomadores apresentam diferentes probabilidades de repagarem seus empréstimos. A taxa de juros que um indivíduo aceita pagar é uma forma de selecionar: aqueles que aceitam juros mais altos são, em geral,

\footnotetext{
52 Além dos benefícios da redução nos custos de transação, a presença do intermediário no mercado financeiro apresenta outros atrativos (van Horne, 1998; Shirota, 1996), como a divisibilidade e flexibilidade das operações (ao acumular a poupança de diversos indivíduos, de diversos tamanhos, pode redistribuir este volume total em empréstimos de acordo com as necessidades de cada tomador); a diversificação das aplicações e conseqüente diluição do risco; pode operar com descasamento de prazos (ou seja, datas de vencimento diferentes) entre as poupanças e os empréstimos; e, pode beneficiar-se do conhecimento proporcionado por sua especialização (por exemplo, formalizar uma hipoteca pode não ser uma tarefa tão trivial para um indivíduo quanto é para um banco).

${ }^{53}$ Havendo pouca informação, os credores selecionam os mutuários em termos mais amplos.
} 
tomadores com maior risco (Stiglitz \& Weiss, 1981). Juros altos inviabilizam os projetos com menor retorno esperado, porém com menor risco. Desta forma, há uma taxa de juros (r* na Figura 19) acima da qual uma elevação dos juros irá selecionar projetos com maior risco, reduzindo o lucro esperado pelo banco (Braga, 2000). O retorno esperado pelo credor é inversamente relacionado ao grau de risco (Stiglitz \& Weiss, 1981). Esta função não monotônica é ilustrada na Figura 19.

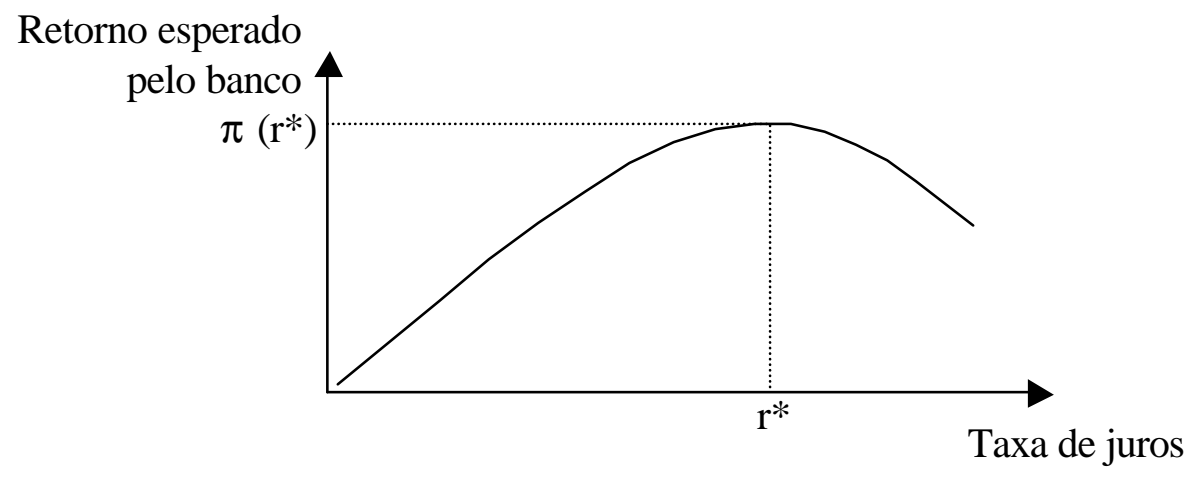

Figura 19 - Existência de taxa de juros que maximiza o retorno esperado pelo banco.

Fonte: Stiglitz \& Weiss (1981)

Estudos de Aryeetey et al. (1997) em países africanos em desenvolvimento confirmam a posição de que os mercados de crédito não são necessariamente Pareto-eficientes ${ }^{54}$, pois ocorre racionamento. Como o banco não identifica claramente e antecipadamente qual é a predisposição de determinado tomador cumprir suas obrigações, ele se utiliza de mecanismos de seleção diferentes da taxa de juros. Bancos de países africanos vêm os pequenos tomadores como sendo de maior risco do que os grandes por razões relacionadas à dificuldade de obter informações

\footnotetext{
${ }^{54}$ Vide Arnott et al. (1993) para uma demonstração elegante de que mercados incompletos e informação imperfeita conduzem a mercados não eficientes de Pareto.
} 
precisas sobre eles, pela dispersão geográfica, analfabetismo, e ao grau de incerteza da renda. Com exigência de garantias e depósitos mínimos, os bancos eliminam os pequenos tomadores do mercado formal (Aryeetey et al., 1997). Entretanto, o nível de exigência de garantia tem efeito similar ao das taxas de juros. Isto é, elevados níveis de garantia também podem levar à seleção adversa (Stiglitz \& Weiss, 1981).

Considerando que a capacidade de captação de recursos de um banco é proporcional ao seu retorno esperado, e que a oferta de crédito é determinada pelo volume de recursos captado pelo banco, tem-se que a curva de oferta apresentará forma similar à apresentada na Figura 19 (Braga, 2000). Assim, a oferta e demanda de crédito podem ser representadas através da Figura 20:

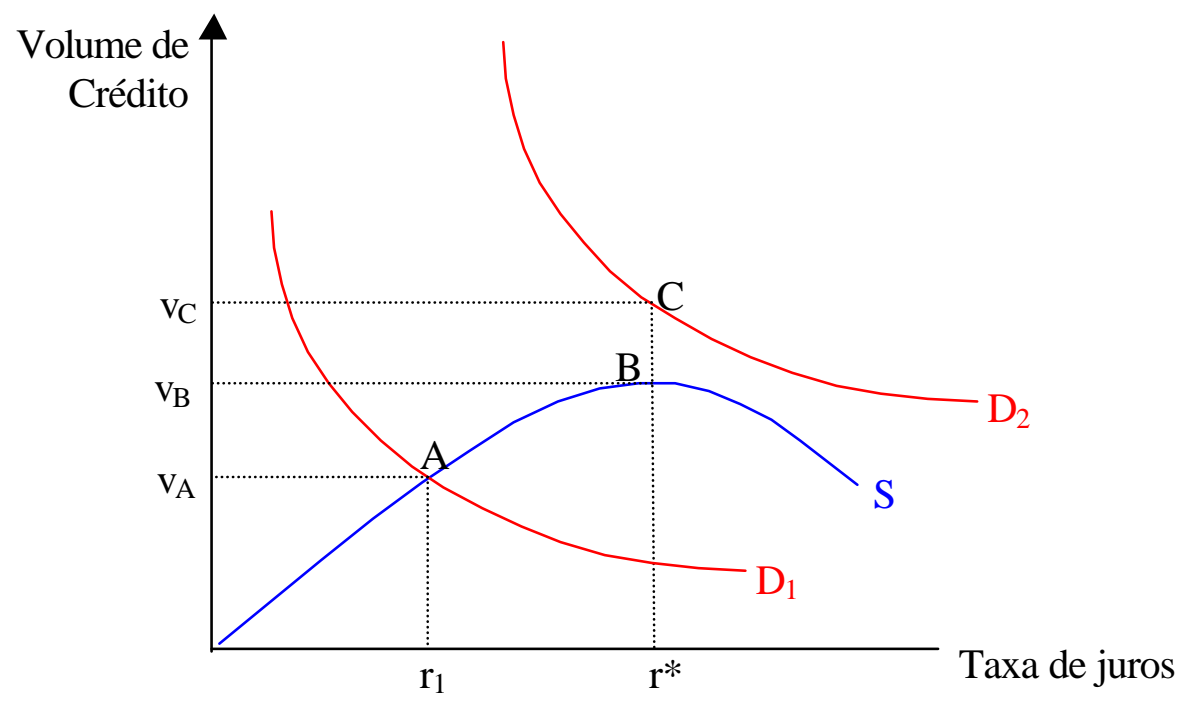

Figura 20 - Racionamento de crédito com intermediação financeira.

Nesta figura são apresentadas duas hipotéticas curvas de demanda de crédito. Na situação representada pela demanda $\mathrm{D}$, o equilíbrio competitivo ocorreria no ponto $\mathrm{A}$, correspondendo a um volume $\mathrm{v}_{\mathrm{A}}$ de crédito a uma taxa de juros $\mathrm{r}_{1}$. No entanto, 
na situação representada pela demanda $\mathrm{D}_{2}$ ocorreria racionamento de crédito: seria ofertado um volume de crédito $v_{B}$ a uma taxa de juros $r^{*}$, sendo que, a esta taxa, a demanda seria de $v_{C}$. Portanto o racionamento seria equivalente a diferença entre $v_{C} e$ VB.

Como os bancos utilizam os custos de transação como um mecanismo de racionamento de crédito, e sendo o poder de racionamento maior quando os custos são mais altos, eles podem não desejar reduzir os custos transacionais (Ladmam, 1984). As instituições financeiras dedicadas ao crédito rural podem buscar no racionamento do crédito uma proteção contra inadimplência em situações onde as taxas de juros são legalmente limitadas a um teto máximo (Bourne \& Graham, 1984).

No entanto, a assimetria de informação ocorre também após a formalização do contrato, seja em decorrência de determinadas ações tomadas pelo devedor e que não são observadas pelo credor, ou pelo resultado de ações da natureza (também observadas somente pelo devedor), e que afetam o retorno esperado do empreendimento. Nesta situação podem ocorrer problemas conhecidos como risco moral $^{55}$. Nas operações de crédito, são diversos os incentivos que resultam em riscos moral (Braga, 2000). Dentre eles, destacam-se três: (i) quando o custo de inadimplência é menor do que o custo de quitar a dívida; (ii) quando, numa situação de inadimplência, a possibilidade de renegociação beneficia o devedor; e, (iii) quando o esforço do devedor na condução do empreendimento financiado não é observado pelo credor.

É possível reduzir o risco financeiro aperfeiçoando e tornando mais disponíveis as informações sobre os mutuários (Banco Mundial, 1989). A assimetria de informação oferece o suporte técnico adequado para a análise econômica do risco de

\footnotetext{
55 A premissa básica de risco moral é que os indivíduos não tem o mesmo incentivo para cuidar da propriedade de outras pessoas com o mesmo zelo com que cuidam de seus próprios interesses, ou seja, há um incentivo menor em zelar pelo dinheiro emprestado do que pelos recursos próprios (Fry, 1995).
} 
inadimplência (Araújo, 1996). Este enfoque tem como base as seguintes considerações (Hoff \& Stiglitz, 1990):

a) os tomadores de crédito diferem na probabilidade em que se tornarão inadimplentes, acarretando custos relativos ao cálculo do risco de cada devedor. Isto é convencionalmente conhecido por problema de seleção (screening problem);

b) é necessário monitorar as atividades dos clientes, para que eles conduzam suas atividades de modo que a quitação dos empréstimos seja a mais provável possível. Este é o denominado problema de incentivo (incentive problem); e,

c) pode ser problemática a quitação do crédito concedido. Este é o problema de execução (enforcement problem).

As instituições financeiras trocam dinheiro hoje pela promessa de dinheiro no futuro, tomando ações que elevem a probabilidade desta promessa ser honrada. Assim, a atividade bancária requer, além da atenção ao retorno dos créditos concedidos, a obtenção de informações sobre variáveis que caracterizam o empreendimento e o tomador (Araújo, 1996). O primeiro item (seleção) refere-se às características dos tomadores, enquanto o segundo (incentivos) está focado no comportamento do cliente. A operação de crédito envolve seleção de tomadores com características muitas vezes ocultas, e deve fornecer incentivos para comportamentos nem sempre observáveis (Stiglitz, 2000). O credito é seguro somente quando há meios fáceis de "fazer valer" (enforcing) o contrato ou há conhecimento do caráter do tomador dos recursos. Desconsiderar esta condição implicará em atrair os "limões" ", acarretando perdas ao emprestador.

${ }^{56}$ Ativos de pior qualidade, de acordo com a terminologia adotada por Akerlof (1970). 
O monitoramento da operação é de particular importância na prevenção e identificação do risco moral. É praticamente impossível saber - antes, durante ou depois de cada evento - qual é o real uso do empréstimo, face a fungibilidade do crédito (o que lhe confere a capacidade de ser livremente alocado ou trocado por outros bens). Mesmo que este risco seja controlado, por exemplo, com a exigência de comprovação das aplicações dos recursos ou liberação de recursos diretamente a fornecedores do mutuário (como ocorre nas operações de FINAME), há outro problema da fungibilidade. Os recursos próprios que seriam utilizados na atividade produtiva podem migrar para alternativas mais rentáveis no mercado, comprometendo a aplicação total e, consequentemente, a produção agrícola.

\subsection{Custos da intermediação financeira}

Um sistema financeiro eficiente - com menores taxas de juros e, o que é particularmente importante no crédito rural, com maior volume de recursos - deve realizar suas transações a um custo mínimo. Isto depende do sucesso na avaliação das alternativas de investimentos e no direcionamento dos recursos disponíveis para estes, além do monitoramento dos tomadores. A intermediação financeira deve proporcionar o uso eficiente dos recursos (escassos) disponíveis (Shirota, 1996).

Entre os custos da intermediação financeira, destaca-se o custo da informação. A informação é um bem fundamentalmente diferente de outras commodities - no item 5.1 deste trabalho o bem informação será melhor caracterizado. Seu consumo é não-rival (ou seja, o consumo por um indivíduo não diminui a quantidade a ser consumida por outros indivíduos), e, mesmo que seja possível (embora quase sempre difícil) excluir terceiros dos benefícios de parte do conhecimento, é 
socialmente ineficiente agir desta forma. Observa-se, também, que os benefícios da informação são crescentes com a escala de utilização, ressaltando que os custos para se obter informação são custos fixos (Stiglitz, 2000).

A relevância do custo da informação decorre do fato da relação contratual entre ofertante e tomador de crédito caracterizar-se como uma relação de agente-principal. Após a concessão do empréstimo, o tomador passa a ser um agente do credor (principal), pois suas decisões com relação ao uso do capital emprestado afetam sua capacidade de saldar a dívida (Lazzarini \& Chaddad, 2000). Esta situação permite que o tomador possa apresentar comportamento oportunista (prejudicando o credor), isto é, há o risco moral.

Uma forma de reduzir o risco moral é através do monitoramento de informações. No entanto, isto pode implicar, para os emprestadores, em despender recursos monitorando as informações observadas pelo tomador. $O$ custo deste monitoramento pode ser bastante elevado, implicando ou em elevados gastos com monitoramento ou no problema do free rider $^{57}$ (neste caso, nenhum credor terá incentivo para monitorar os créditos, pois, se empregar seus recursos para este fim, arcará integralmente com os custos, mas sua parcela de benefício sobre o monitoramento - que interessa a todos - será pequena). O melhor seria um credor monitorar em benefício de todos, ou seja, que o monitoramento fosse delegado (Diamond, 1984; Briss \& Welch, 2001).

No caso do devedor não honrar o contrato na data prevista, o credor irá se deparar com dois custos adicionais. Primeiro, será necessário avaliar (ou reavaliar) a garantia e os ativos que possam ser exigidos para liquidação do débito. Em segundo

\footnotetext{
${ }^{57}$ Free riders são aqueles que "pegam carona" no esforço alheio, e lucram com isto. Na produção privada (e na venda de informação), free riders aparecem, pois podem imitar o comportamento de quem pagou pelo uso ou geração da informação para melhorar a qualidade de seus investimentos (Hillbrecht, 1999).
} 
lugar, há o custo de executar a dívida, de "fazer valer" (enforcement) as cláusulas contratuais (Agénor \& Aizenman, 1999).

Segundo Guidetti \& Araujo (1994), o custo bancário de transação no Brasil é elevado, com casos acima dos níveis internacionais estimados em países de baixa renda. Este custo, para as operações de crédito rural, relaciona-se a três parâmetros importantes: (i) valor médio do contrato; (ii) volume de aplicações pela agência em crédito rural; e, (iii) proporção das aplicações totais da agência correspondente ao crédito rural.

Os custos de monitoramento nas operações rurais tendem a ser elevados, uma vez que conceder crédito para agricultura implica em financiar uma atividade que se desenvolve a céu aberto. Monitorar ocorrências de pragas e doenças, variáveis climáticas (como, por exemplo, temperatura e precipitação pluviométrica), entre outros eventos, é uma tarefa complexa e muitas vezes inviável. Estas atividades, em geral, exigem uma grande especialização do profissional responsável pela identificação dos riscos, sua administração e monitoramento. Esta característica do crédito rural implica em custos não desprezíveis, mas cuja experiência (o "aprender fazendo") resulta em redução do custo unitário de cada operação. Ou seja, quanto maior for a produção, maior será a experiência (e o aprendizado) do profissional. Isto ocorrerá até que seja atingido um limite no qual a redução do custo a cada aumento de escala deixa de acontecer em função de fatores como a maior necessidade de controles (maior burocracia) e outras complexidades decorrentes da maior escala. Esta dinâmica é uma das características de economia de escala ${ }^{58}$ (Scherer \& Ross, 1990).

Entretanto, as provas empíricas indicam que quando um banco ultrapassa um tamanho moderado, as probabilidades são de que as economias de escalas sejam

\footnotetext{
${ }^{58}$ Uma função custo $C$ apresenta economia de escala se ao nível de produção $q$ tem-se $C(\lambda . q)<\lambda$.C(q) para todo $\lambda>1$ (Baumol et al., 1988). Uma definição mais precisa será apresentada na seqüência do texto.
} 
modestas (Mayer et al., 1995, p.123) ${ }^{59}$. Neste sentido, observa-se que a principal despesa dos bancos, a mão-de-obra, está mais próxima de ser considerada um custo variável do que fixo. Muitos bancos têm sistemas de dimensionamento de mão-de-obra com base em volumes processados (Oliveira, J., 2001).

$\mathrm{Na}$ indústria bancária, a ineficiência resultante da escala de atuação dos intermediários financeiros é relativamente baixa, inferior a $10 \%{ }^{60}$. Isto porque a superfície da curva de custo médio (em formato de "U") são achatadas nesta indústria. Isto indica que a expansão do tamanho dos bancos pequenos não resulta em significativas economias no custo, e o crescimento dos bancos muito grandes implicam na elevação do custo médio (Shirota, 1996).

Economia de Escala $^{61}$ surge quando o custo unitário de produção decresce à medida que o nível de produção (escala) se eleva. No caso de uma firma que produz apenas um produto, a medida da economia de escala em um nível de produção $y$ é dada pela definição:

Definição 1: O grau de economia de escala ao nível de produção y é:

$$
S(y)=\frac{C(y)}{y C^{\prime}(y)}=\frac{C M e(y)}{C M a(y)}
$$

\footnotetext{
${ }^{59}$ Baumol et al. (1988) já apresentavam conclusões similares, referindo-se aos trabalhos:

GILLIGANT, T.; SMIRLOCK, M. An empirical study of joint production and scale economies in commercial banking. Journal of Banking and Finance, n.8, p.67-77, 1984

GILLIGANT, T.; SMIRLOCK, M.; MARSHALL, W. Scale and scope economies in the multi-product banking firm. Journal of Monetary Economies, n.13, p.393-405, 1984.

${ }^{60}$ A combinação não apropriada de insumos/fatores na produção apresenta impacto mais forte nos custos bancários. Este tipo de ineficiência representa um incremento de $35 \%$ no custo médio em estudos realizados com dados do setor bancário norte-americano (Shirota, 1996).

${ }^{61} \mathrm{O}$ referencial teórico sobre economia de escala que é apresentado na seqüência do texto está baseado em Baumol et al. (1988) e Shirota (1996).
} 
em que $C M e(y)$ é o custo médio ao nível de produção $y$; e, $C M a(y)$ é o custo marginal ao nível de produção $y$. Retornos a escala são crescentes, constantes, ou decrescentes se $S(y)$ for maior, igual ou menor do que um, respectivamente. Este conceito é representado na Figura 21.

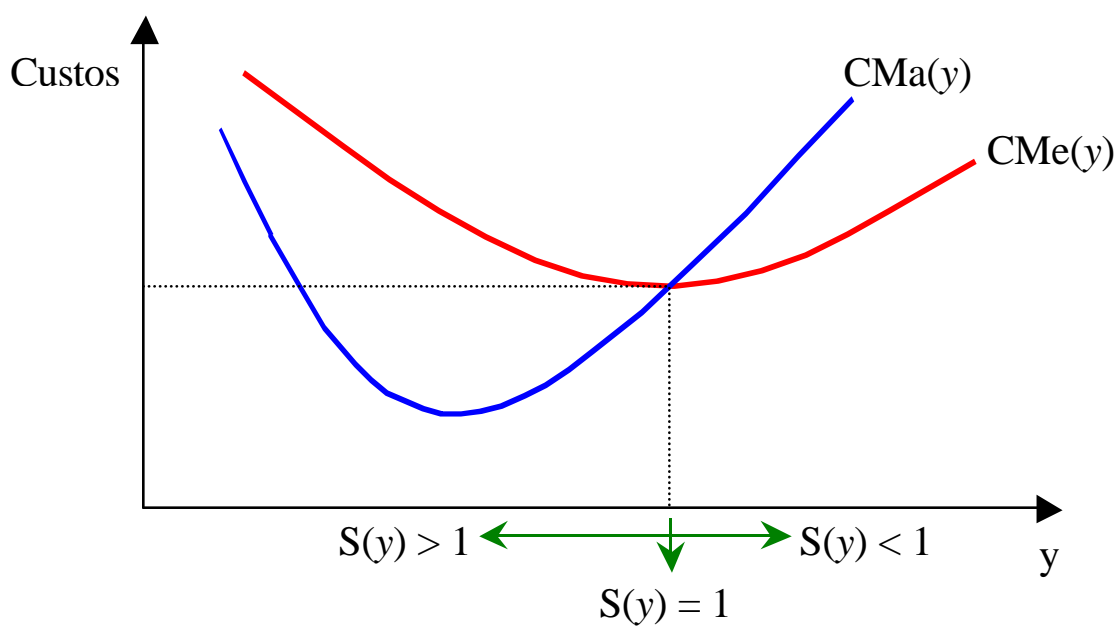

Figura 21 - Custo Médio (CMe), Custo Marginal (CMa), e sua relação com economia de escala $[S(y)]$ para o caso de um único produto.

Entretanto, os intermediários financeiros são, em geral, firmas que produzem diversos bens e serviços, isto é, multiproduto. Bancos operam com diversas linhas de financiamento além do crédito rural, realizam captação de depósitos a vista e a prazo, administram recursos de terceiros, entre outras atividades. Indústrias de nsumos e tradings que concedem financiamento ao produtor rural claramente são multiproduto. $\mathrm{O}$ conceito de economia de escala é bastante intuitivo no caso de produto único: a quantidade de produto aumenta ou diminui. No caso multiproduto é necessário definir melhor a variação no nível de produção. A função custo, agora, é representada por uma hipersuperfície na dimensão da produção (número de bens e serviços diferentes 
produzidos). A Figura 22 apresenta um exemplo hipotético de superfície de custo para dois produtos distintos.

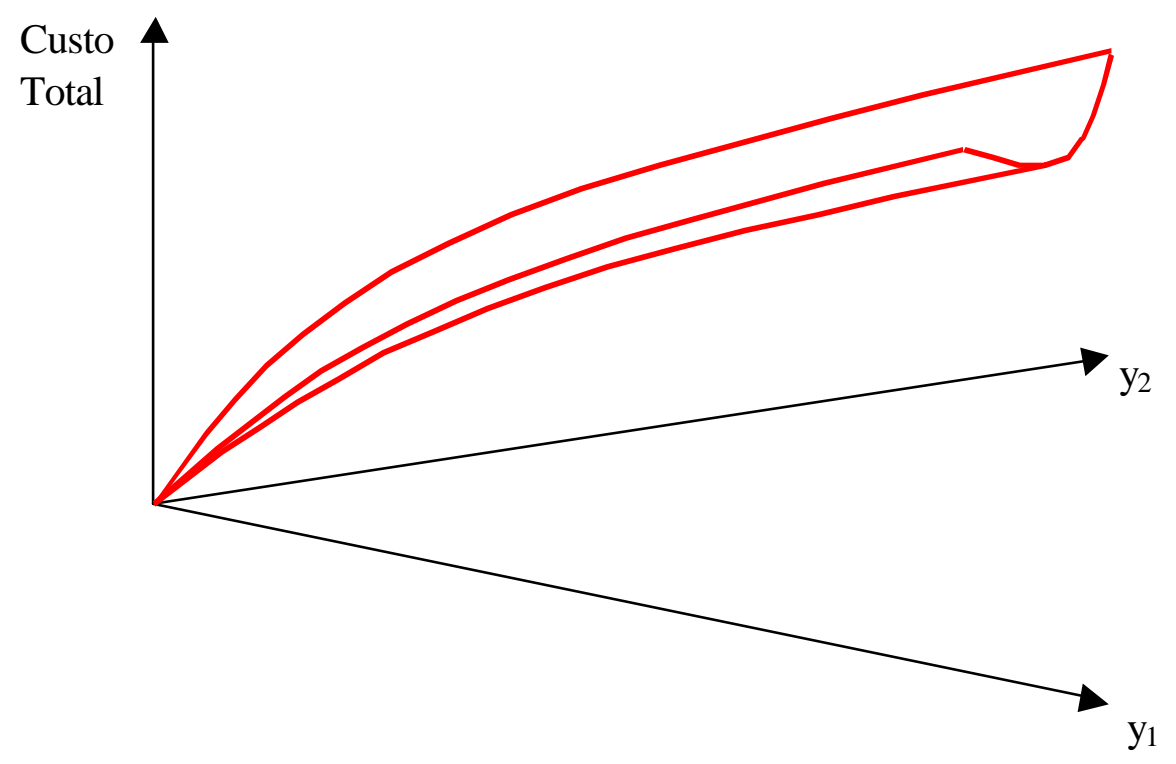

Figura 22 - Superfície de custo hipotética para o caso de dois produtos.

A Figura 23 mostra quatro diferentes maneiras como a produção pode variar no caso de duas dimensões ${ }^{62}$. A mudança de escala de $V$ para $T$ é a mais simples, representando um incremento de um produto $\left(y_{2}\right)$ enquanto o outro $\left(y_{1}\right)$ permanece constante (Expansão Produto-Específica). A linha $O C$ representa a mudança que mantém as proporções dos produtos fixas (Expansão de Raio). A mudança representada pela linha $R S$ corresponde ao aumento de um produto enquanto o outro decresce em proporção linear (Trans-Raio). E, a mudança representada pela linha $A B$ é o movimento

${ }^{62} \mathrm{O}$ caso de duas dimensões é mostrado pela facilidade da representação gráfica. No entanto, o conceito pode ser generalizado para o caso de $n$ produtos $(n>1)$. 
de um ponto arbitrário $A$ para outro $B$ (Caminho de Expansão). Para os objetivos deste estudo, a economia de escala produto-específica é a mais relevante ${ }^{63}$.

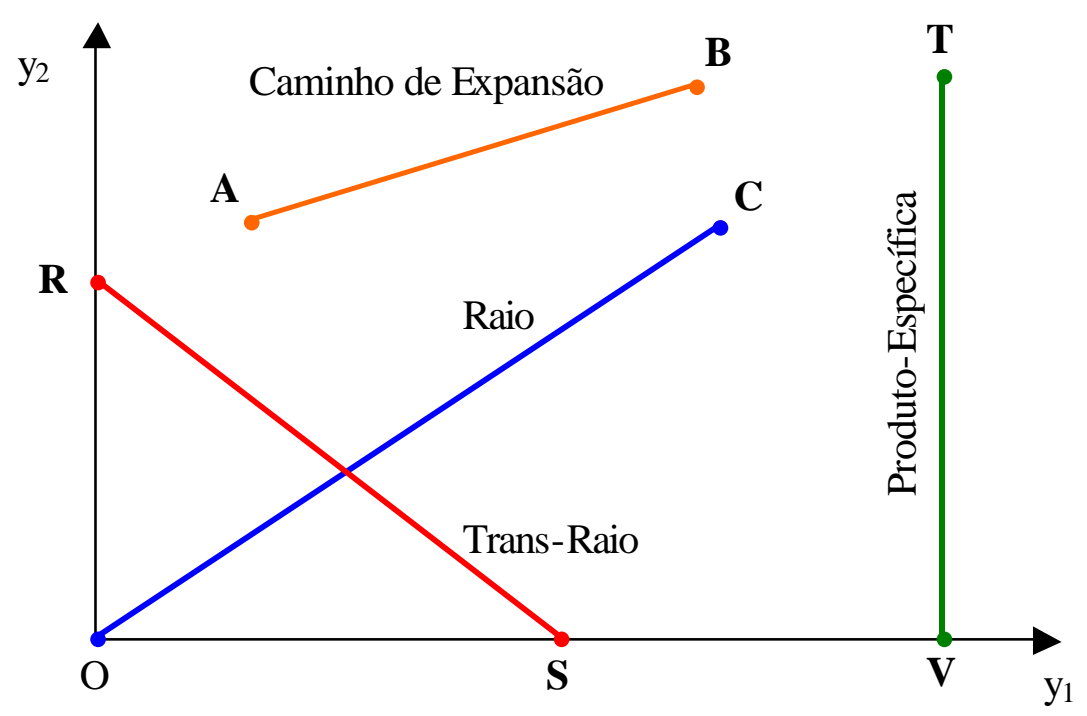

Figura 23 - Exemplos de mudanças na escala e na composição de produtos no caso de dois produtos.

Economia de escala produto-específica é mensurada pela proporção entre custo médio e o custo marginal referente a um dado produto $y_{\mathrm{i}}$. Mais formalmente, temse:

Definição 2: $\mathrm{O}$ custo incremental do produto $i \in N$ ao nível de produção $y$ é:

${ }^{63} \mathrm{O}$ problema analisado refere-se a alterações apenas no volume de crédito rural. 


$$
C I_{i}(y)=C(y)-C\left(y_{N-1}\right)
$$

em que $y_{\mathrm{N}-1}$ é um vetor com o componente zero no lugar de $y_{\mathrm{i}} \mathrm{e}$ os demais componentes iguais ao $y$ de cada produto remanescente.

Definição 3: O custo incremental médio do produto $i$ avaliado ao nível de produção $y$ é:

$$
\operatorname{CIMe}_{i}(y)=\frac{C I_{i}(y)}{y_{i}}
$$

Assim,

Definição 4: Economia de Escala Produto-Específica é definida por:

$$
S_{i}(y)=\frac{C I_{i}(y)}{y_{i} C_{i}} \equiv \frac{C I M e_{i}(y)}{\frac{\partial C}{\partial y_{i}}}
$$

Economia de escala do produto $i$ ao nível de produção $y$ é dita crescente, decrescente ou constante se $S_{i}(y)$ for maior, menor ou igual a um, respectivamente.

As características específicas do crédito rural favorecem o surgimento de economia de escala. Por exemplo, os custos ligados ao contato com o cliente nas propriedades rurais, em geral, distantes geograficamente da agência do credor. Os deslocamentos físicos (incluindo transporte, estadia, refeições etc.), como nas visitas ao cliente (para contatos comerciais ou monitoramento), representam custos não 
desprezíveis que podem ser diluídos com o aumento do número de clientes em uma mesma região, que pudessem ser visitados em uma única viagem. Informações climáticas necessárias para acompanhar o risco de um cliente são válidas para clientes da mesma região. Enfim, características como a dispersão geográfica dos produtores rurais e a ocorrência de eventos generalizados na agricultura favorecem o surgimento de economia de escala no crédito rural.

Observa-se empiricamente ${ }^{64}$ que o tamanho da carteira e o grau de especialização em operações de crédito rural implicam em substancial redução dos custos médios de transação. A maior especialização em crédito rural das agências do banco possibilitam, com melhor aproveitamento dos recursos disponíveis, redução no custo total de transação. Adicionalmente, aumentando o tamanho da carteira de empréstimos, o custo total aumenta menos que proporcionalmente ao tamanho da escala de operações do banco. Em função disto, o custo total da transação por real emprestado diminui quando se aumenta a escala de operações.

Estudo $^{65}$ anterior já havia apontado que os fatores relacionados à escala de operações da agência (tamanho da carteira e o valor médio dos contratos) são os que apresentam melhores oportunidades de redução substancial dos custos de transação.

Economia de escopo também está presente quando a indústria bancária opera com crédito rural. Economia de escopo ocorre sempre que o custo de produção conjunta é menor que o custo total de produção independente ${ }^{66}$ (Baumol et al., 1988).

\footnotetext{
64 As observações a seguir são de Guidetti (1998) referente ao estudo que realizou envolvendo 205 agências de um banco comercial.

${ }^{65}$ Pessôa (1996) analisou o custo bancário de 62 agências de quatro bancos oficiais.

${ }^{66}$ Isto é, $C\left(y_{1}, y_{2}\right)<C\left(y_{1}, 0\right)+C\left(0, y_{2}\right)$.
} 
$\mathrm{Na}$ intermediação financeira a informação é um insumo que uma vez adquirido para a produção de um serviço torna-se disponível, sem custos relevantes, para a produção de outros serviços ${ }^{67}$. Ou seja, assumindo que há $n$ processos produção ${ }^{68}$ :

$$
y_{i}=f^{i}\left(\mathbf{z}^{i}, K\right) \quad i=1, \ldots, n .
$$

em que:

$\boldsymbol{z}^{i}$ é um vetor de insumos utilizados na produção do serviço $i$; e, $K$ é o insumo informação.

Ou, adotando uma representação equivalente da tecnologia de produção que expressa o custo mínimo $\left(V^{i}\right)$ de produção do serviço i como uma função de sua própria quantidade $\left(y_{i} *\right)$, da quantidade de informação $(K)$, e do vetor de preços dos demais insumos $\left(\mathbf{w}^{j}\right)$, tem-se:

$$
V^{i}\left(y_{i}, K, \mathbf{w}\right)=\min _{z^{i}}\left[z^{i} \mathbf{w} \mid f^{i}\left(z^{i}, K\right) \geq y_{i}\right] \quad i=1, \ldots, n .
$$

Assume-se que a informação é ao menos fracamente produtiva na sua utilização. Ou seja,

$$
V^{i}\left(y_{i}, K_{1}\right) \geq V^{i}\left(y_{i}, K_{2}\right) \quad \text { para } \quad K_{2} \geq K_{1}, i=1, \ldots, n .
$$

\footnotetext{
${ }^{67}$ Vide item 5.1.

${ }^{68}$ Adaptado de Baumol et al. (1988).
} 
Adicionalmente, assume-se que a informação é um insumo essencial para a intermediação financeira, ou seja, $f^{i}\left(\mathbf{z}^{i}, 0\right)=0$.

Um intermediário financeiro que produz a um custo mínimo algum conjunto de serviços $T_{j}$ em quantidade $y_{T j}$ tem como função objetivo $(F O)$ :

$$
F O=\min _{K} \sum_{i \in T_{j}} V^{i}\left(y_{i}, K\right)+\beta K
$$

em que $\beta$ é o custo de adquirir a informação.

Seja $K_{T_{j}}^{*}$ a solução da eq. (8). Então,

$$
C\left(y_{T_{j}}\right)=\sum_{i \in T_{j}} V^{i}\left(y_{i}, K_{T_{j}}^{*}\right)+\beta K_{T_{j}}^{*}
$$

Seja $\left\{T_{1}, \ldots, T_{k}\right\}$ uma partição não trivial de $N$, então a função custo será:

$$
\bar{C}(y) \equiv \sum_{j=1 i \in T_{j}}^{k} \sum^{i}\left(y_{i}, \bar{K}\right)+\beta \bar{K}
$$

em que

$$
\bar{K}=\max _{j} K_{T_{j}}^{*} \quad j=1, \ldots, k .
$$

Então, 


$$
\left.\bar{C}(y)-\sum_{j=1}^{k} C\left(y_{T_{j}}\right)=\sum_{j=1 i \in T_{j}}^{k} \sum_{V^{i}}\left(y_{i}, \bar{K}\right)-V^{i}\left(y_{i}, K_{T_{j}}^{*}\right)\right]+\beta\left[\bar{K}-\sum_{j=1}^{k} K_{T_{j}}^{*}\right]
$$

De acordo com as assunções realizadas [eq. (7) e eq. (11)], ambos termos do lado direito da eq. (12) são não positivos, com ao menos um estritamente negativo. Uma vez que $C(y)$ é definido como sendo a função de custo mínimo, então $C(y) \leq \bar{C}(y)$ $\mathrm{e}$,

$$
C(y)-\sum_{j=1}^{k} C\left(y_{T_{j}}\right) \leq \bar{C}(y)-\sum_{j=1}^{k} C\left(y_{T_{j}}\right)<0
$$

Para $y>0$, a ineq. (13) é a definição de economia de escopo.

Assim, quando um banco já possui uma agência instalada em uma cidade operando com produtos diferentes do crédito rural (conta corrente, por exemplo), a introdução de operações de crédito rural poderá ser feita utilizando a estrutura física e pessoal já existente para diversas operações (como, por exemplo, confecção de cadastro, processamento de dados, entre outras). Também poderá se utilizar de informações do cliente e das suas operações por fontes adicionais àquelas que teria se operasse exclusivamente com o crédito rural. Este é o caso, por exemplo, do cliente que movimenta a sua conta corrente ou realiza seus investimentos na mesma agência onde realiza financiamento rural (Berger et al., 1987). Esta situação permite o monitoramento do fluxo de caixa do tomador. 


\subsection{Inadimplência e o acesso ao crédito bancário}

Entre os determinantes da restrição ao acesso ao crédito, destaca-se a inadimplência. Mesmo as renegociações de dívidas rurais, ocorridas nos anos 90 com objetivo de reduzir a inadimplência, contribuíram para tornar os bancos mais seletivos, restringindo o acesso ao crédito (Faveret Filho, 2002).

Nesse sentido, entre as verificações empíricas de acesso ao crédito, observa-se que (Carvalho \& Barcelos, 2002):

- tomadores com maior transparência contábil (como aqueles que adotam padrões contábeis diferenciados e publicam seus balanços patrimoniais) apresentam maior facilidade para acessar financiamento;

- a eficiência do sistema judiciário é fator determinante na facilidade com que os credores podem tomar posse de suas garantias. Assim, empresas localizadas em estados onde o judiciário é mais ineficiente apresentam maior dificuldade para acessar crédito. E,

- tanto o tamanho da empresa quanto o grau de imobilização afetam positivamente o acesso ao crédito.

Face à incerteza quanto à quitação do empréstimo, o ofertante de crédito incorpora um prêmio de risco à taxa de juros. Como não há um mecanismo que identifique, a priori, a probabilidade de inadimplência, os ofertantes de crédito avaliam esse risco com base em característica dos tomadores. Estas características podem ser classificadas em três grupos (Araújo, 1996): 
a) variáveis de potencialidade: terra, benfeitorias, máquinas, equipamentos, rebanhos, garantias e reciprocidade bancária;

b) variáveis demográficas: idade, região, sexo, número de dependentes, participação em associações de classe, escolaridade, tipo de direito sobe a terra e religião; e,

c) indicadores econômicos: atividade econômica, quantidade de mão-de-obra contratada, tecnologia, propriedades, risco medido pela variância de preços, produção, renda, insumos utilizados, dívidas e capital próprio.

O custo do dinheiro para o tomador de crédito, sob a hipótese de $100 \%$ de adimplência, pode ser representado pela seguinte equação ${ }^{69}$ :

$$
\begin{gathered}
R_{t}=F+T \\
T=T_{f}+T_{a}+T_{p}
\end{gathered}
$$

em que:

$R_{t}=$ taxa de juros cobrados do tomador $t$; expressa na forma unitária;

$F=$ custo de captação dos recursos para o ofertante de crédito;

$T=$ custos operacionais;

$T_{f}=$ custo de aquisição de informação;

$T_{a}=$ custos de transação pré-contratuais;

$T_{p}=$ custos de transação pós-contratuais.

Se uma parcela do crédito concedido não é quitada, o tomador não estará saldando uma parte dos custos operacionais $(T)$ e parte dos custos de captação $(F)$. Assim, a inadimplência resulta em perdas não somente do principal, mas também dos

${ }^{69}$ Adaptado de Lazzarini \& Chaddad (2000). 
custos de captação e operacionais (Araújo, 1996). Então, o prêmio de risco $\left(P_{r}\right)$, originado das perdas associadas à inadimplência $(I)$, é definido como:

$$
\begin{gathered}
P_{r}=\frac{I(1+F+T)}{1-I} \\
0 \leq I \leq 1
\end{gathered}
$$

O custo de realizar empréstimos $(C E)$, para o ofertante do crédito, será $^{70}$ :

$$
C E=F+T+\frac{I(1+F+T)}{1-I}
$$

Derivando parcialmente a eq. (18) com relação a seus componentes, obtém-se:

$$
\begin{gathered}
\frac{\partial C E}{\partial F}=1+\frac{I}{1-I}=\frac{1-I}{(1-I)^{2}} \\
\frac{\partial C E}{\partial T}=1+\frac{I}{1-I}=\frac{1-I}{(1-I)^{2}} \\
\frac{\partial C E}{\partial I}=\frac{(1+F+T)}{(1-I)^{2}}
\end{gathered}
$$

\footnotetext{
${ }^{70}$ Baseado em Araújo (1996).
} 
Considerando que:

$$
1+F+T>1-I
$$

Tem-se:

$$
\frac{\partial C E}{\partial I}>\frac{\partial C E}{\partial F}=\frac{\partial C E}{\partial T}
$$

Como as variáveis expressam razões, as derivadas parciais representam elasticidades. Portanto, o efeito de uma redução marginal na inadimplência é maior que a queda em qualquer um dos outros componentes do custo de emprestar $(C E)$. Esta importância da inadimplência no custo torna relevante uma classificação dos créditos quanto ao risco, sendo a oferta de financiamento influenciada por esta classificação.

Anteriormente ao desenvolvimento de teoria referente à assimetria de informação e racionamento de crédito, as variáveis mais utilizadas na classificação de créditos, e que determinavam a oferta de crédito, $\operatorname{eram}^{71}$ : (i) liquidez e capacidade de pagamento (medida por: ativo circulante/passivo circulante; fluxo de caixa/valor do crédito; e, valor do empréstimo/renda líquida); (ii) solvência (medida por: despesas anuais/ativo; dívida/capital próprio; e, dívida/ativo); (iii) lucratividade (medida por lucro líquido/ativo); e, (iv) garantias (medida por garantias/valor de crédito).

Com o desenvolvimento da teoria referente à assimetria de informação, novos modelos surgiram. Jaffee \& Russell (1976) desenvolveram um modelo considerando dois tipos de tomadores de recursos. Clientes que quitam seus empréstimos, mesmo quando houver incentivos para se tornarem inadimplentes, foram

\footnotetext{
${ }^{71}$ Araújo (1996) apresenta uma revisão dos modelos de classificação de riscos de crédito utilizados até os anos 80 .
} 
denominados honestos. Os clientes do outro grupo, que não quitam os empréstimos mesmo quando a inadimplência não é vantajosa economicamente, foram denominados desonestos. Por hipótese, assume-se que não é possível distinguir esses clientes antes da concessão do empréstimo. Considerando os efeitos da seleção adversa, o modelo mostra que a oferta de crédito estaria relacionada à proporção entre clientes honestos e desonestos na população. Nessas situações, mecanismos diversos de incentivos, como a restrição ao acesso a novos empréstimos aos maus pagadores, assumiram crescente importância no mercado de crédito (Hoff \& Stiglitz, 1990). 


\section{DETERMINAÇÃO DA ESTRUTURA DE MERCADO}

O fato da indústria do crédito rural apresentar economias de escala e de escopo poderia sugerir que se trata de um monopólio natural. Para verificar esta hipótese é necessário identificar se há subaditividade do custo. Esta é uma característica que define um monopólio natural de uma forma superior que noções como o retorno crescente à escala.

A função custo é subaditiva para um determinado vetor $y$ de produção quando $y$ pode ser produzido de forma mais barata por uma única firma do que por alguma combinação de firmas menores. Ressalte-se que subaditividade é um conceito global $^{72}$ (Baumol et al., 1988). Considerando o que foi apresentado nas seções anteriores deste trabalho, subaditividade dos custos do crédito rural é uma característica da indústria bancária. Este é o caso, por exemplo, de um dos principais componentes dos custos de transação: a perda por inadimplência.

A inadimplência do crédito rural pode originar-se de vários fatores. Primeiro, pode ser resultado de eventos alheios a vontade do tomador do empréstimo, como, por exemplo, uma seca que comprometa a produção agrícola (e conseqüente capacidade de geração de caixa do devedor). Considerando a inexistência (ao menos atual) de seguro agrícola, a diluição da carteira em regiões geográficas com diferentes

\footnotetext{
${ }^{72}$ Ou seja, subaditividade da função custo, isto é, quando $C(q)<C(x)+C(q-x)$ para qualquer $x$ tal que $0<x<q$, onde $q$ é o nível de produto total, é um conceito válido para qualquer escala ou combinação de produtos (Farina, 1990).
} 
características climáticas e edafológicas diluiria o percentual de perda na carteira do banco. Portanto, neste aspecto, é mais interessante ter um banco atuando globalmente do que diversos bancos, cada um atuando localmente. Segundo, o monitoramento, como já discutido, é essencial para reduzir a inadimplência. Para tanto, diversos instrumentos podem ser utilizados. Fotos aéreas ou imagens de satélites são úteis para monitorar uma propriedade ou diversas, a um mesmo custo total. Ou seja, o custo unitário é decrescente. Investimentos em equipes de profissionais especializados em crédito e agricultura também apresentam subaditividade. Esforços no recebimento (enforcement) e obtenção de informações melhores e em maior quantidade, que contribuam para redução da inadimplência, são mais eficientes quanto menor é o número de credores, pois, neste caso, há maior dependência do tomador (pois terá menos alternativas de crédito).

Outros custos de transação também apresentam subaditividade, destacando-se o custo de informação, já discutido. Enfim, a subaditividade dos custos é uma característica da indústria do crédito rural, o que é uma condição necessária para a existência do monopólio natural.

Quando o monopólio ou o oligopólio são resultantes da presença de subaditividade de custos, em mercados livres, não é possível e nem desejável a coexistência de um grande número de concorrentes $^{73}$. Entretanto, se uma indústria é controlada por um monopolista, não há garantia de que o consumidor se beneficiará dos menores custos. Sem concorrência, não há incentivo para inovação tecnológica e busca de taxas crescentes de produtividade (Baumol et al., 1988). Setores onde se verificam subaditividade de custos e elevados custos fixos constituídos por ativos específicos,

\footnotetext{
${ }^{73}$ A estrutura da indústria pode não ser estável. Neste caso, um concorrente potencial poderá estabelecer um plano lucrativo de entrada, ao produzir uma quantidade ligeiramente menor do que a do monopolista, a um preço também menor, sem atender toda demanda de mercado àquele preço (Farina, 1990).
} 
características do monopólio natural, a regulamentação é uma alternativa a ser fortemente considerada, apesar de não ser a solução ideal ${ }^{74}$.

No caso do mercado financeiro, que apresenta subaditividade de custos, a presença do governo, regulamentando o mercado financeiro, pode ser vista, também, através da análise apresentada a seguir (Fry, 1995).

Uma função essencial do mercado financeiro é coletar, processar e transmitir informação para a alocação de fundos e monitorar o seu uso. Informações dispendiosas criam falhas de mercado.

Uma falha de mercado decorre do custo da informação porque o monitoramento possui características de não-rivalidade ${ }^{75}$. E, consequentemente, há subinvestimento em monitoramento. Quando as instituições financeiras sabem que não são adequadamente monitoradas pelos depositantes (isto é, seus credores), elas têm incentivos em tomar maiores riscos com os seus depósitos. Com informação imperfeita, o mercado é ineficiente, mesmo se for competitivo. Então, a intervenção do governo pode acrescentar bem-estar. O governo desempenha um papel de segurador (querendo ou não) dos bancos, pois em muitos casos o problema de um banco afeta todo o sistema. Nesta ótica, a regulamentação do mercado financeiro pode ser vista sob a perspectiva de uma empresa seguradora que impõe condições para operar no mercado.

Observa-se que, ao contrário dos depositantes, os tomadores de recursos não podem facilmente trocar de bancos (Fry, 1995). Primeiramente porque a informação sobre um potencial cliente, prospectivo, envolve custo fixo. O banco que já opera com

\footnotetext{
74 Segundo Milton Friedman, citado por Farina et al. (1997), "não existe, infelizmente, uma boa solução para o monopólio técnico. Existe apenas uma escolha entre três demônios: o monopólio privado desregulamentado, o monopólio privado regulamentado pelo Estado e a produção estatal".

${ }^{75}$ Os bens não-rivais são aqueles bens ou serviços que, uma vez produzidos, estão disponíveis a todos consumidores sem rivalidade, ou seja, o consumo do bem ou serviço por um indivíduo não afeta a quantidade disponível desse mesmo bem ou serviço para os outros (Randall, 1987).
} 
este tomador de recursos já incorreu neste custo. Isto produz um elemento de monopólio natural favorável ao atual banco do cliente. Em segundo lugar, o novo banco, o que desejaria conquistar o cliente, pode não realizar operações uma vez que se defronta com seleção adversa: ficaria sem resposta para a questão se o atual banco do cliente não estaria atendendo a demanda porque aquele cliente não seria mais um bom risco ou porque não é competitivo.

Adicionalmente, os bancos adquirem informações sobre os tomadores de recursos ao realizarem suas operações. Desta forma, ao longo do tempo, a assimetria de informação tende a diminuir. $O$ custo gerado pela seleção adversa é maior para os potenciais competidores que desejem entrar no mercado do que para os bancos já instalados. A seleção adversa representa uma barreira a entrada. As informações adquiridas implicam em certo grau de poder de monopólio aos bancos que já operam no mercado, limitando o número de competidores no mercado (Dell'Ariccia, 2001).

Os problemas que surgem no mercado financeiro sugerem que esse mercado é candidato a uma intervenção governamental (Stiglitz, 1990). Mas deve-se ter em mente que os problemas não são menores no setor público do que no setor privado, pois:

"Alterar a esfera de decisão não altera as dificuldades associadas à seleção e à monitoração. Mas, para piorar a questão, o governo, com freqüência, não tem incentivos para assegurar que ele (ou seus agentes) faça um bom trabalho na seleção e na monitoração de empréstimos. O bolso fundo do governo significa que quaisquer perdas podem ser facilmente compensadas. Além disso, como os critérios econômicos são, freqüentemente, suplementados por outros critérios (poupar empregos, desenvolvimento regional), as perdas podem não ser responsabilidade da incapacidade de fazer julgamentos sobre solvência, mas dos critérios não-econômicos que têm sido impostos. A ausência do teste de controle do mercado significa que o crédito pode ser alocado com base no favoritismo político (...)" (Stiglitz, 1990, p. 282). 
A revisão da literatura, contemplando diversos estudos com amostras distintas geográfica e temporalmente, indica a subaditividade dos custos de transação no crédito rural. Isto implica na viabilidade do monopólio nesta indústria.

Observa-se um desinteresse do setor bancário privado (de um modo geral) em atuar nesta área. Destaca-se que quanto maiores forem os custos de transação, maior será o poder de racionamento. Isto implica em maior seleção dos clientes, permitindo uma proteção contra inadimplência em situações onde as taxas de juros são legalmente limitadas a um teto máximo. Adicionalmente, observa-se que os bancos brasileiros não tem tradição em operar, em larga escala, linhas de crédito para agricultura, sendo assim, será necessário implantar carteiras agrícolas que operem com eficiência (Pessôa, 1996).

Neste sentido, o Banco do Brasil poderia se tornar monopolista no segmento de crédito rural. Isto em função de sua posição ímpar no mercado brasileiro de crédito rural, destacando sua presença em 4.240 municípios (o que representa $83 \%$ do total de municípios assistidos com crédito rural no Brasil) ${ }^{76}$; de sua estrutura; e, de sua histórica posição de principal agente da política oficial para o setor. Com o monopólio na concessão de crédito rural, o Banco do Brasil poderia extrair ao máximo os benefícios de ganhos da economia de escala e de escopo, dada a subaditividade dos custos de transação. Isto permitiria uma redução nos custos totais que ou tornaria rentável a carteira de crédito rural (o que muitas vezes não ocorre) ou, ao menos, minimizaria a necessidade de equalizações ou subsídios por parte da União.

No entanto, nada asseguraria eficiência nas operações e o bem-estar dos agricultores numa situação de monopólio. A indústria bancária é não-contestável (Dell'Ariccia, 2001). A necessidade de regulamentação do mercado é inquestionável,

${ }^{76}$ BACEN (2001). 
mas talvez não seja o suficiente (há falhas também de governo, e não apenas de mercado).

Dentre os custos de transação, destacam-se aqueles ligados à informação. Uma menor assimetria de informação permitiria seleção e monitoramento mais eficazes e eficientes. Nota-se que a informação pode ser caracterizada como uma barreira à entrada. Instituiçõos que desejarem entrar no mercado devem optar ou por custos irrecuperáveis para atingirem um nível satisfatório de informação, ou por operar sem quantidade e qualidade adequada de conhecimento. No primeiro caso, há necessidade de escala na operação. No segundo caso, o risco moral será elevado, assim como a seleção adversa, e a instituição optará por não entrar neste "mercado de limões".

Caso os intermediários financeiros compartilhassem suas informações, isto levaria a um ambiente de competição perfeita, onde o lucro econômico seria nulo para os bancos. Assim, não há incentivo para troca de informações. Somente nos casos em que o risco moral é elevado é que o compartilhamento de informações surge como uma solução de mercado (Dell' Ariccia, 2001).

Instituições locais, tais como aquelas ligadas ao microcrédito e agências locais de crédito $^{77}$, possivelmente apresentariam eficiência igual ou mesmo maior que o Banco do Brasil (destacado pela sua relevância, já analisada, no mercado brasileiro) na obtenção e tratamento da informação junto aos tomadores de recursos. Mas seriam, também, um intermediário entre ofertantes e tomadores de recursos.

A presença deste intermediário implica numa relação principalintermediário-agente, que pode resultar em um problema tipo principal-agente/principalagente. Ou seja, na relação com o tomador dos recursos, o intermediário é o principal, mas na relação com o aplicador dos recursos será o agente. Considerando que o

\footnotetext{
${ }^{77}$ Para detalhes, vide Toneto Junior \& Gremaud (2001) e:

DIAS, G. (Ministério Desenvolvimento Agrário, Brasília). Palestra, 2000.
} 
intermediário terá inúmeras relações com os diversos indivíduos, suas ações oportunísticas podem ter um efeito agregado significativamente maior do que se as relações fossem individuais. Assim, é necessário que ocorra a chamada regulação social, para proteção dos indivíduos (ou firmas) que confiam suas ações aos intermediários, mas que, isoladamente, não tem como monitorar tais ações (Braga, 2000).

As recentes dificuldades enfrentadas pelo Grameen Bank ilustram que mesmo as instituições de microcrédito perdem eficiência em mercados competitivos (Pearl \& Phillips, 2002). O sucesso do Grameen Bank ocorreu quando este era monopolista no mercado em que atuava. Em 1997, menos de 5\% dos empréstimos do Grameen estavam há mais de dois anos atrasados. Em agosto de 2002, quando o Grameen estava concorrendo com outras sete instituições de microcrédito na área de Tangai, a inadimplência nesta região elevou-se para 32,1\% dos empréstimos em atraso há mais de dois anos. Na época, entre $23 \%$ e $40 \%$ das famílias que tomaram empréstimo em Tangai obtiveram recursos de mais de uma instituição. 


\section{INFORMAÇÃO E CAPITAL SOCIAL}

\subsection{Informação}

Informação é um fator de produção, isto é, um bem consumido durante a prestação dos serviços que caracterizam a intermediação financeira. Aquele que vai conceder crédito deve gastar recursos para levantar informações referentes ao potencial tomador dos recursos. Geralmente, o intermediário financeiro baseia sua decisão de fornecer crédito em "sinais" tais como (Lazzarini \& Chaddad, 2000): caráter do tomador de crédito (honestidade, integridade, estabilidade financeira); histórico de crédito (reputação do tomador junto a outros credores); e, avaliação financeira de seus negócios (capital próprio, lucratividade, capacidade de repagamento da dívida). Adicionalmente, informação deve ser adquirida para o monitoramento do risco. A informação possui um elevado custo de produção e um baixo custo de reprodução. Em mercados competitivos, os preços tendem ao custo marginal, que neste caso (reprodução) é próximo de zero. Esta propriedade poderia sugerir, equivocadamente, que a forma eficiente de transacionar o bem informação seria gratuitamente (Shapiro \& Varian, 1997). Outra característica da informação é que o seu custo é irrecuperável (sunk cost), ou seja, ele 
ocorre antes do término da produção e não é recuperado no caso de insucesso na concretização da operação (Varian, 1998).

Duas importantes características do bem informação destacam-se: é um bem que deve ser experimentado (experience good); e, é um bem não-rival (desconsiderando uma eventual utilização estratégica, como instrumento de competição). A compra de uma informação está diretamente associada ao seu conteúdo. Entretanto, em geral, se um vendedor revelar o conteúdo da informação que ele deseja vender ao comprador (antes que este a compre), rão haverá motivos para o consumidor pagar por ela. Caso o vendedor possua boa reputação, permitindo a formação de expectativa com relação à qualidade da informação, haverá, então, motivação para precificação do bem informação. O mercado deste bem é inerentemente caracterizado por imperfeições de informação quanto ao que está sendo comprado (Stiglitz, 2000). Assim, há o problema, para o vendedor, de não poder mostrar seu produto para a apreciação do comprador (pois, se assim o fizesse, estaria entregando o produto antes de tê-lo comercializado). Para o comprador, há o problema de não saber ao certo o que estará adquirindo (Varian, 1998).

Desta forma, na hipótese de um intermediário desejar vender a informação que detém sobre determinado crédito, irá se defrontar com o receio dos potenciais compradores quanto a qualidade da mesma. Em particular, pode ser questionado se não há qualquer tipo de viés na informação ofertada, de modo a atender aos interesses do vendedor ${ }^{78}$.

Em geral, a informação apresenta não-rivalidade no consumo, isto é, a quantidade de informação consumida por uma pessoa não reduz a quantidade remanescente para os outros consumidores. Quando um bem, uma vez disponível para uma pessoa, também fica disponível - sem custo adicional - para outras pessoas, a

\footnotetext{
${ }^{78}$ Este é o caso, por exemplo, do credor de um mau pagador, que pode, através de informação viesada, induzir outro agente a conceder um crédito para que o devedor liquide sua antiga dívida.
} 
produção e o suprimento das quantidades socialmente desejáveis não são viabilizados pelo mecanismo de mercado livre (Ely, 1986).

A eficiência de Pareto no mercado de um bem não-rival (neste caso, a informação), implica que cada indivíduo paga um preço marginal igual ao seu valor marginal para o bem (Randall, 1987). Como o valor marginal varia de indivíduo para indivíduo, o preço deveria ser personalizado. $\mathrm{Na}$ prática, isto é inviável tanto pela impossibilidade (muitas vezes legal) de praticar preços discriminatórios, quanto, principalmente, pela necessidade de se conhecer as preferências de cada consumidor. No caso de bens não-rivais, estabelecer preço não discriminatório não é eficiente, pois excluiria indivíduos que poderiam consumir o bem sem custo adicional para o fornecedor.

Novas informações obtidas por uma empresa em geral são de grande utilidade para as empresas concorrentes. Uma vez produzida, a informação pode ser compartilhada por várias pessoas de forma não-rival, sem custo marginal relevante. Para evitar situações favoráveis aos concorrentes, a geração de informação ocorre de forma ineficiente. Isto porque a sua produção pode ocorrer de forma duplicada, isto é, diversas firmas incorrendo em custos para a obtenção do mesmo produto (informação) que poderia ter sido gerado uma única vez e multiplicado sem custos adicionais. Ou, pode gerar um subinvestimento na geração de conhecimentos que não possam ser consumidos com exclusividade, mas que poderiam conduzir a um melhor conhecimento do cliente e de sua operação.

Observa-se que há um esforço excessivo (duplicidade de custos) na busca de dados cadastrais e informações que auxiliem o monitoramento das operações de crédito, gerando informações idênticas para as firmas. Como este esforço poderia ser menor, é evidente a ineficiência do processo de exploração sob a ótica econômica. O valor social da informação gerada é, na prática, inferior ao que poderia ser (Pêssôa, 1996). 
Informações de mercado são essenciais para o funcionamento eficiente do mercado financeiro. E quanto mais fragmentado e imperfeito for o mercado, mais valiosa será a informação (Johnson, 1994).

No caso de financiamentos agrícolas, os custos de informação em geral são mais elevados em função da infra-estrutura de transporte e de comunicação ser, na maior parte das regiões, menos desenvolvida que nas áreas urbanas (Meyer \& Nagarajan, 2000).

\subsection{Capital social}

Os custos e as dificuldades na obtenção e processamento de informações tornaram o capital social um conceito com utilização crescente nas ferramentas de decisão referentes a oferta de crédito. $\mathrm{Na}$ presente seção, é apresentado o conceito de capital social. Nas próximas serão mostrados os desafios na sua mensuração e as diversas aplicações na área de crédito.

A visão econômica dominante (neoclássica), cujas raízes encontram-se em Adam Smith, considera a sociedade como um conjunto de indivíduos independentes, cada um buscando isoladamente atingir seus objetivos. $\mathrm{O}$ funcionamento da sociedade corresponderia ao conjunto das ações destes indivíduos buscando, cada um, a maximização de sua utilidade. A competição perfeita expressa bem esta idéia, simbolicamente representada pela "mão invisível" de Smith. Diversos autores - como 
Loury, Granovetter, Lin e Coleman, entre outros $^{79}$ - buscam caracterizar o indivíduo como um ser mais socializado, menos egoísta, com relacionamentos pessoais e redes de relações. A interdependência social e o funcionamento do sistema surgem do fato de que os agentes têm interesses em eventos que estão totalmente ou parcialmente sob o controle de outros agentes. O resultado de vários tipos de trocas e de transferências de controles realizadas pelos agentes na busca de seus interesses formam as relações sociais que persistem no tempo. Estas relações não são simplesmente componentes da estrutura social, mas importantes recursos disponíveis aos indivíduos (Coleman, 1990). O capital social corresponde ao tecido social, à cola invisível que mantém a coesão das sociedades. Trata-se de um conceito que amplia e complementa a teoria neoclássica (Peres, 2000). É um dos elementos que compõem o conjunto de estoques de capitais que condicionam o crescimento econômico (Figura 24).

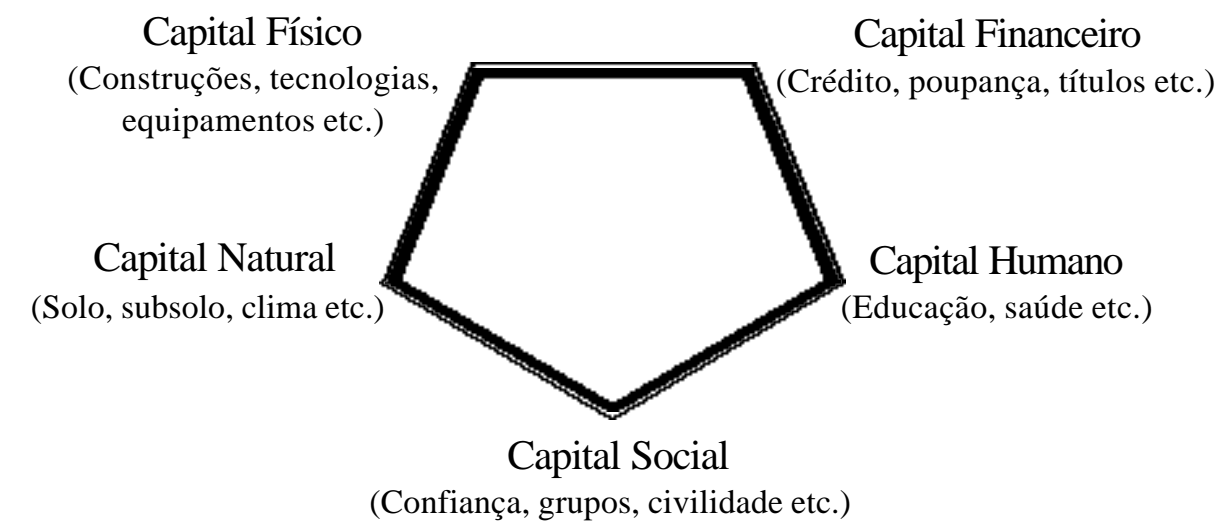

Figura 24 - Conjunto de estoques de capitais que condicionam o crescimento das economias.

Fonte: Baseado em Peres (2000)

${ }^{79}$ Vide Coleman (1990). 
Embora o uso do conceito de capital social date de $1916^{80}$, somente a partir da década de 90 do século passado que o conceito de capital social despertou especial, e crescente, atenção de cientistas sociais. Uma definição deste conceito é dada por Sobel (2002, p.139): Social capital describes circumstances in which individuals can use membership in groups and networks to secure benefits ${ }^{81}$." Na realidade, não há um único objeto chamado capital social, mas diversos, que juntos podem ser chamados de capital social (Dasgupta, 2002). Ou seja, o capital social é multifacetado (Sobel, 2002). Desta forma, sempre que se vai fazer uso do termo, há necessidade de definir como ele será utilizado. Para um melhor entendimento do conceito é conveniente uma breve revisão da sua história recente.

Nos últimos 25 anos têm-se atribuído a Robert Putnam e James Coleman os créditos por colocar em evidência o termo "capital social" (Feldman \& Assaf, 1999). Putnam visualizou capital social como um conjunto de associações horizontais entre pessoas que cooperam para o benefício mútuo da comunidade. James Coleman ampliou esta definição ao incluir relações verticais, caracterizadas por relações hierárquicas e distribuição desigual de poder. Uma terceira visão de capital social passou a incluir o ambiente político e social que forma a estrutura social e estabelece normas para seu desenvolvimento (Grootaert \& van Bastelaer, 2001). Este foco nas instituições - como o regime político e o sistema judiciário, entre outras - caracteriza os trabalhos de pesquisadores como Douglas North e Mancur Olson. Efetivamente, o valor do capital social e a sua utilização dependem do ambiente institucional (Sobel, 2002).

Estas três visões de capital social, partindo de um conceito de associações locais horizontais, em geral informais, caminhando até a inclusão de

\footnotetext{
${ }^{80}$ Conforme Narayan (1999), o primeiro uso do termo capital social ocorreu em 1916 no artigo:

HANIFAN, L.J. The rural school community center. In: THE AMERICAN ACADEMY OF POLITICAL AND SOCIAL SCIENCE, 67. Annals. s.n.t. p.130-138.

No entanto, Alfred Marshall já havia utilizado a expressão "capital social" em 1890, mas com um significado diferente do atual (Grootaert \& van Bastelaer, 2001).

81 Tradução: o capital social descreve circunstâncias nas quais os indivíduos podem utilizar filiação em grupos e redes de relacionamentos para assegurarem benefícios.
} 
associações hierárquicas e estruturas nacionais formais (como governo e judiciário) apresentam características comuns (Grootaert, 1998):

- todas interligam as esferas econômica, social e política. Elas consideram que relações sociais afetam os resultados econômicos e são afetado por eles;

- todas reconhecem o potencial criado pelas relações sociais em melhorar os resultados do desenvolvimento mas também reconhecem o risco de externalidades negativas. Qual resultado prevalecerá dependerá da natureza da relação (horizontal versus hierárquica) e do contexto legal e político;

- todas enfocam as relações entre agentes econômicos, e como a organização formal ou informal destes pode melhorar a eficiência de atividades econômicas; e,

- todas implicam que relações sociais e instituições "desejáveis" possuem externalidades positivas. Como estas não podem ser apropriadas por qualquer um individualmente, cada agente tem uma tendência para subinvestir em capital social. Consequentemente, há um papel do setor público no suporte à construção de capital social.

James Coleman - sociólogo interessado no papel do capital social na criação de capital humano e de resultados na educação (Narayan \& Cassidy, 2001) define "capital social" por sua função. Para Coleman, capital social não é uma única entidade, mas uma variedade de diferentes entidades que possuem duas características em comum: todas consistem em algum aspecto de uma estrutura social, e facilitam ações de indivíduos que pertencem a esta estrutura. Como outras formas de capital, o capital social é produtivo e torna possível a realização de objetivos que não seriam atingíveis em sua ausência. Como o capital físico e o humano, o capital social não é completamente fungível, mas o é com respeito a atividades específicas. Uma 
determinada forma de capital social que é valiosa como facilitadora de certas ações, pode ser inútil ou até mesmo prejudicial para outras (Coleman, 1990).

O capital físico é completamente tangível, na forma de material observável. O capital humano é menos tangível, representado pelas habilidades e conhecimentos adquiridos por um indivíduo. Já o capital social é ainda menos tangível, pois mistura-se nas estruturas de relações pessoais e interpessoais.

A distinção entre capitais humano e social pode ser representada por um diagrama como na Figura 25, que representa as relações entre três pessoas $(A, B$ e $C)$. $\mathrm{O}$ capital humano é representado pelos nós; e o capital social pelas linhas que conectam os nós. Capital social e capital humano freqüentemente são complementares.

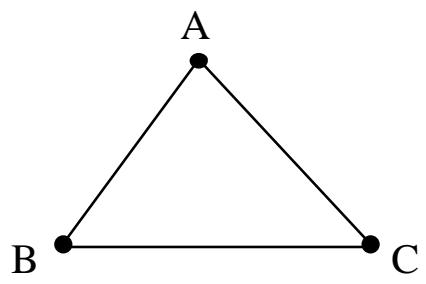

Figura 25 - Estrutura com três pessoas: capital humano nos nós e capital social nas relações.

Fonte: Baseado em Coleman (1990)

O valor do capital social está, primeiramente, no fato de identificar certos aspectos da estrutura social pelas suas funções ${ }^{82}$. A função identificada pelo conceito de

${ }^{82}$ Da mesma forma que, por exemplo, independente de forma, aparência e material de sua composição, identificamos uma caneta por sua função (ou seja, um objeto em que se coloca uma pena metálica para que se possa escrever). 
"capital social" é o valor destes aspectos da estrutura social para os agentes como recursos que poderão utilizar para atingirem seus objetivos, seus interesses (Coleman, 1988).

Destacam-se três formas do conceito de capital social: obrigações e expectativas, que dependem de probidade do ambiente social, geração de informação pela estrutura social, e normas acompanhadas de sanções. Uma propriedade comum à maioria das formas de capital social que o diferencia de outras formas de capital é seu aspecto de bem público: o agente ou agentes que geram capital social, em geral, capturam só uma parte pequena de seus benefícios, um fato que conduz a um subinvestimento em capital social.

\section{Obrigações e expectativas:}

Se $A$ faz algo para $B$ e crê que $B$ reciprocará no futuro, isto estabelece uma expectativa em $A$ e uma obrigação para $B$. Esta obrigação pode ser vista como um "crédito" detido por $A$ que será desempenhado por $B$. Se $A$ possuir um grande número de créditos, referente a diversas pessoas com as quais $A$ se relaciona, a analogia com capital financeiro é imediata. Estes créditos constituem uma "carteira" que $A$ poderá exigir se necessário - a menos que tenha depositado confiança equivocadamente, e estes créditos ruins não serão pagos. Esta forma de capital social depende de dois elementos: probidade do ambiente social, indicando que as obrigações serão pagas, e o volume de obrigações assumidas. As estruturas sociais variam nestas duas dimensões, e os agentes numa mesma estrutura diferem quanto ao volume de obrigações assumidas. Um exemplo de probidade do ambiente social é o das associações de crédito rotativo (ROSCAs) do sudeste asiático e da África, que serão detalhadas adiante, no item 5.4. 
Informação:

Uma forma importante de capital social é a informação que surge em relações sociais. Informação é importante para embasar qualquer ação. Mas a aquisição de informação é onerosa. No mínimo, requer atenção, que é sempre um fator escasso. Um meio pelo qual informação pode ser adquirida é através do uso de relações sociais que são mantidas por outros propósitos. As relações, neste caso, não são valorizadas na forma de obrigações detidas por uns para performance de outros ou para a probidade da outra parte, mas somente pela informação que elas geram, facilitadoras de ações.

Normas acompanhadas de sanções:

Norma é uma espécie de princípio de preceito, um mandamento. Geralmente decorre de um juízo de comportamento imperativo, ou seja, que impõe um dever. Em muitos casos (normas jurídicas), além de imperativa (como no campo da moral), é atributiva, isto é, confere direitos a outrem (Palaia, 2002).

Quando uma norma existe e é efetiva, então ela constitui uma poderosa forma de capital social. Esta não apenas facilita certas ações, mas restringe as indesejáveis. Por exemplo, comunidades que têm normas direcionando jovens para esportes, estão canalizando as energias destes para longe de atividades indesejadas.

Todas relações e estruturas sociais facilitam alguma forma de capital social; agentes estabelecem relações propositadamente e continuamente enquanto estiverem proporcionando benefícios. No entanto, certos tipos de estrutura social são especialmente importantes como facilitadoras de algumas formas de capital social: fechamento da estrutura social e apropriação de organização social (Coleman, 1988). 
Numa estrutura social com abertura, como a representada m Figura 26.a, o agente $A$, que se relaciona com $B$ e $C$, pode impor ações que provocam externalidades negativas em $B$ e $C$, ou em ambos. Uma vez que estes não se relacionam entre si, mas com outros ( $D$ e $E$, respectivamente), eles não podem combinar suas forças para impor sanções à $A$. Já numa estrutura com fechamento, como representado na Figura 26.b, $B$ e $C$ poderiam aplicar coletivamente sanções à $A$.

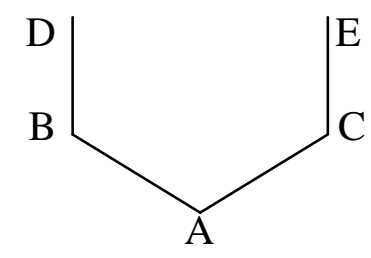

(a)

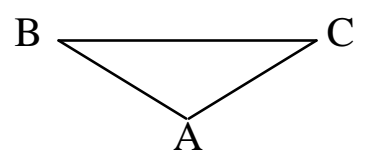

(b)

Figura 26 - Estrutura social (a) com abertura e (b) com fechamento.

Fonte: Baseado em Coleman (1990)

O fechamento de uma estrutura social é importante não somente por tornar normas efetivas, mas também por outra forma de capital social: a probidade. Reputação não surge em uma estrutura aberta e sanções que assegurariam a probidade não são aplicáveis. $\mathrm{O}$ fechamento propicia probidade em uma estrutura social.

Externalidade positiva de uma organização social ocorre quando uma pessoa tem obrigações em um contexto e é chamada a socorrer outra que tem problemas em outro contexto. Por exemplo, quando parentes trocam informações sobre problemas nas escolas dos filhos ou quando as obrigações que uma pessoa deve em um relacionamento $X$ podem ser usadas para constranger as suas ações em outro relacionamento $(Y)$. 
Em sua concepção original, o capital social seria um facilitador da ação coletiva. No entanto, conforme destacado por Young (2001), este conceito foi ampliado, mostrando que o capital social afeta o comportamento dos indivíduos ao contribuir para a conscientização da extensão das relações interpessoais. O capital social permite que cidadãos resolvam problemas coletivos mais facilmente, pois as pessoas superam a inércia e o receio do free riding que normalmente impedem ações coletivas. Assim, o capital social reduz os custos de transações atrelados aos comportamentos oportunísticos. O menor incentivo a este tipo de comportamento reduz o risco moral, diminuindo os custos de monitoramento.

O capital social é utilizado como variável exógena no mercado de crédito. Por exemplo, uma explicação racional para os elevados diferenciais de taxas de juros reais verificados entre países, baseia-se fundamentalmente em um argumento de probidade. Observa-se que países com má reputação histórica na gerência da dívida pública só conseguem ofertar uma quantidade de títulos igual à de um país com alta credibilidade a taxas de juros mais elevadas (Gonçalves \& Kanczuk, 2001).

O capital social afeta o desempenho do Judiciário, poder responsável pela solução de conflitos, em tornar efetivas as normas (Oliveira, A., 2001). No caso do Brasil, onde as leis que definem os direitos dos credores são federais mas aplicadas por tribunais estaduais, é possível avaliar o impacto da ineficiência judicial sobre os mercados de crédito de cada Estado. A ineficiência judicial é um fator que limita o volume de crédito $^{83}$ (Pinheiro \& Cabral, 1998). Estudo empírico apresentou resultados indicando que a falta de um desempenho judicial adequado reduz significativamente a razão crédito/PIB, mesmo depois de se controlar para diferenças no nível de renda per capita. A análise de regressão mostrou que "a ineficiência judicial tem um impacto negativo pronunciado tanto no volume de crédito rural quanto não rural" (Pinheiro \&

\footnotetext{
83 Observa-se, também, que a ineficiência judicial eleva os custos de transação, aumentando em até $30 \%$ o spread bancário (Pinheiro \& Cabral, 1998).
} 
Cabral, 1998, p.67). O mesmo estudo apresenta outras conclusões relevantes, mostrando que arranjos alternativos buscam compensar a ineficiência do judiciário (quando esta ocorre), tais como:

a) existência de uma infra-estrutura bem estruturada na captação, armazenamento e disseminação de informação nos mercados competitivos, como no de crédito pessoal (por exemplo, com agências privadas de crédito, como SERASA e SCI);

b) presença de bancos públicos em segmentos não competitivos, onde o bom comportamento do devedor é essencial para obtenção de novos créditos (uma vez que, nestes casos, não há alternativa de novas fontes de crédito); e,

c) mecanismos que contam com a pressão de pares para assegurar o repagamento (conforme será discutido na seção 5.4).

\subsection{Mensuração do capital social}

"The iconoclastic Nobel laureate in physics, Richard Feynman, suggested that he chose a career in physics over the social sciences because social science problems are more difficult (...) this difficulty stems in part from the problem of measurement ${ }^{84}$."

(Narayan \& Cassidy, 2001, p.3)

\footnotetext{
84 Tradução: O iconoclasta laureado pelo Nobel em física, Richard Feynman, insinuou que ele escolheu uma carreira em física, e não em ciências sociais, porque os problemas nas ciência sociais são mais difíceis (...) esta dificuldade origina-se em parte do problema de mensuração.
} 
A importância do capital social no acesso a recursos tem sido amplamente aceita. A despeito das diferentes definições de capital social observadas na literatura, há uma elevada consistência entre elas, inclusive nas formas e dimensões. No entanto, do ponto de vista prático, as interpretações do que é ou não capital social tem sido as mais diversas, implicando em variados métodos para sua mensuração ${ }^{85}$ (Narayan \& Cassidy, 2001). Não há um consenso de qual(is) indicador(es) melhor prediz a relação entre capital social e o objeto do estudo (Bebbington, 1999). As diferentes definições e aplicações do conceito de capital social permitiram que cada pesquisador utilizasse seu próprio método ad hoc (Hjđlund \& Svendsen, 2000). Criou-se, assim, uma lacuna na literatura quanto a forma de mensurar o capital social.

No entanto, duas abordagens tem prevalecido (Guiso et al., 2000): uma baseada em pesquisas de opinião (questionários) medindo quanto as pessoas confiam nas outras; e, outra, observando o comportamento das pessoas, como, por exemplo, através do engajamento cívico. A primeira abordagem (questionários) possui a limitação de que as pessoas que respondem à pesquisa divergem em confiabilidade, honestidade. Isto afeta a resposta (por exemplo, como tratar a resposta de alguém não confiável?). A segunda abordagem (observação do comportamento) também possui limitações. Uma elevada participação em eleições é motivada por confiança no sistema eleitoral ou por senso de obrigação? Não se conhece a motivação, apenas o resultado.

A seguir é apresentada uma relação dos diversos métodos adotados para mensurar capital social.

Putnam $^{86}$, conforme Hjđllund \& Svendsen (2000), analisou a diferença na eficiência das instituições, e seus efeitos no desenvolvimento econômico, entre o

\footnotetext{
${ }^{85}$ Neste sentido, o apêndice do artigo de Narayan \& Cassidy (2001) apresenta diversas recomendações e sugestões de itens para mensurar capital social.

86 PUTNAM, R.D. Making democracy work: civic traditions in modern Italy. Princeton: Princeton University Press, 1993.
} 
norte e o sul da Itália. Considerou como medida de capital social o número de associados a organizações voluntárias.

A participação em eleições tem sido utilizada para medir o capital social. Esta escolha é justificada pela alta correlação deste indicador com outras medidas de capital social; por ser uma medida de baixo erro e facilidade na obtenção dos dados; e, por não ser influenciada por variáveis econômicas ${ }^{87}$ (Guiso et al., 2000). Por outro lado, a utilização da participação de eleitores é criticada com o argumento de que uma votação não indica o quanto os indivíduos confiam em outros (Costa \& Kahn, 2001).

Informações sobre a cultura política (normas e valores), corrupção (qualidade das instituições) e tempo gasto em atividades sociais (realizando trabalho voluntário e visitando amigos) têm sido coletadas através de questionários (Hjđlund \& Svendsen, 2000; Costa \& Kahn, 2001; DiPasquale \& Glaeser, 1998). A análise de componentes principais complementa estes estudos, permitindo a definição das variáveis relevantes. Krishna \& Shrader $^{88}$, conforme Hjdlund \& Svendsen (2000), elaboraram um amplo questionário buscando incluir todos os possíveis aspectos do capital social.

Alguns estudos utilizaram os dados da World Values Survey ${ }^{89}$ (Knack \& Keefer, 1997; La Porta et al., 1997; Arraes \& Barreto, 2002). Estes dados estão focados em confiança (trust) e na filiação a diversos tipos de associações (Narayan \& Cassidy, 2001).

\footnotetext{
${ }^{87}$ Por exemplo, a presença de emissoras de rádio ou jornais locais dependem de investimentos financeiros e não apenas sociais.

88 KRISHNA, A.; SHRADER, E. Social capital assessment tool. In: CONFERENCE ON SOCIAL CAPITAL AND POVERTY REDUCTION. Conference paper. s.l.: World Bank, 1999.

89 A World Values Survey (Pesquisa Mundial de Valores) é uma investigação mundial de mudanças socioculturais e políticas. Pesquisa os valores básicos e convicções públicas em mais de 65 sociedades em todos os seis continentes, abrangendo quase 80 por cento da população do mundo.
} 
O capital social também já foi medido pelo número e tipos de relacionamentos, com objetivos comerciais, utilizados pelos traders agrícolas (Fafchamps \& Minten, 1999).

Também foram realizadas estimativas do capital social no Brasil. Para tanto, Bialoskorski Neto (2001) utilizou como variáveis: a proporções de igrejas e capelas existentes em cada região; a proporção de produtores rurais associados a cooperativas; a proporção de produtores rurais em associações de produtores; e, a proporção de produtores rurais associados a sindicatos. Arraes \& Barreto (2002) consideraram as abstenções nas eleições estaduais para estimar o capital social nos Estados brasileiros. O argumento que justificou a escolha desta variável foi que a participação da população no processo político reduziria a chance de ter um eleitorado cativo, reduzindo as chances de políticas públicas sujeitas ao ativismo de grupos de interesse. Bernardes (2002) utilizou diversas variáveis para representar associativismo, civismo e confiança, tais como o número de estabelecimentos de atividades de: organizações empresariais e patronais; organizações profissionais; sindicais; religiosos; distribuição de filmes e videos; teatro; entre outras atividades sociais.

Outros indicadores têm sido utilizados, como o New South Wales; o Barômetro de Capital Social, da Colômbia; o Index of National Civic Health, da National Commission of Civic Health (Estados Unidos); e, o GSCS - Global Social Capital Survey (Narayan \& Cassidy, 2001).

Em linhas gerais, duas características têm predominado na mensuração de capital social: confiança (trust) e filiação (associação) a organizações voluntárias (Hjdlund \& Svendsen, 2000; Narayan \& Cassidy, 2001). Ressalte-se que diversos estudos tem apontado a forte correlação entre os indicadores de capital social, confiança (trust) e medidas de civismo (Guiso et al., 2000). 
Os indicadores de capital social que têm sido utilizados em estudos empíricos são (Grootaert, 1998):

- Associações horizontais

- Número e tipo de associações ou instituições locais

- Número de associados

- Proporção de participação na tomada de decisão

- Extensão de homogeneidade familiar dentro da associação

- Extensão de renda e homogeneidade de ocupação dentro da associação

- Extensão de confiança interpessoal na comunidade

- Extensão de confiança no governo

- Extensão de confiança em associações comerciais

- Percepção da extensão da organização da sociedade

- Confiança em redes de relacionamento

- Porcentagem da renda familiar originada de transferências

- Porcentagem de despesa doméstica com presentes e transferências

- Proporção de dependentes idosos

- $\quad$ Sociedade civil e política

- Índice de liberdades civis (Gastil, Freedom House)

- Porcentagem de população que enfrenta discriminação política

- Índice de intensidade de discriminação política

- Porcentagem de população que enfrenta discriminação econômica

- Índice de intensidade de discriminação econômica

- Porcentagem de população envolvida em movimentos separatistas

- Índice de Gastil de direitos políticos

- Freedom House Index de liberdades políticas

- Índice de democracia 
- Índice de corrupção

- Índice de ineficiência governamental

- Força das instituições democráticas

- Medidas de "liberdade humana"

- Medidas de estabilidade política

- Grau de descentralização de governo

- Comparecimento de eleitor em eleições

- Assassinatos políticos

- Mudanças na Constituição

- Golpes

- Integração social

- Indicador de mobilidade social

- Medida de força das "tensões sociais"

- Fragmentação etno-lingüística

- Revoltas e demonstrações de protesto

- Greves

- Taxas de homicídios

- Taxas de suicídios

- Outras taxas de crime

- Prisioneiros por 100.000 habitantes

- Taxas de ilegitimidade

- Porcentagem de mães/pais solteiros

- Taxa de divórcios

- Taxa de desemprego dos jovens

- Legal e aspectos de governança

- Qualidade de burocracia 
- Independência do judiciário

- Risco de expropriação e de nacionalização

- Quebra contratual pelo governo

- Execução contratual

Os indicadores de associação horizontal consideram uma microperspectiva e tipicamente tem sido coletados para análises dentro de um país. Os outros conjuntos de indicadores têm sido calculados em nível nacional e têm sido utilizados em comparações entre países (Grootaert, 1998).

Por outro lado, alguns pesquisadores mais ortodoxos são contrários a uma visão de capital social. Para eles, o conceito estaria em desacordo com a visão econômica neoclássica ${ }^{90}$. Haveria um equívoco em ver o capital social somente como uma característica de grupo e não individual, da pessoa. Argumentam que, para o grupo, o capital social deve ser uma função de ações e atributos individuais. Redes de relacionamento não seriam resultados de "acidentes históricos", mas de tempo e energia gastos por indivíduos em se conectarem uns aos outros. A base do capital social estaria em características sociais do indivíduo, como carisma, status e acesso a redes de relacionamentos, o que permitiria a uma pessoa extrair retornos de sua interação social. A partir deste raciocínio, realizaram experimentos para testar confiança (trust) e probidade (trustworthiness) em experimentos envolvendo recompensas monetárias para testar as preferências (e atitudes) dos indivíduos estudados. Entretanto, este tipo de procedimento não é adequado, pois não considera o capital em todas suas dimensões ${ }^{91}$ (Monastério (2000).

Grootaert \& van Bastelaer (2001) alertam que há uma perigosa tendência de considerar capital social tudo o que não se classifica nas categorias convencionais de

\footnotetext{
${ }^{90}$ O trabalho de Glaeser et al. (1999) é bastante representativo desta corrente. Glaeser et al. (2000) ratificam esta posição.

${ }^{91}$ Em especial, as características decorrentes da intensidade de suas externalidades.
} 
capital natural, físico, e humano. E um conceito muito amplo implica no risco de não explicar nada. Assim, o desafio para o pesquisador é dar um conteúdo significativo e pragmático à noção de capital social em cada contexto, para que se possa definir indicadores satisfatórios. O desafio de medida é identificar, no contexto da pesquisa, um indicador pertinente de capital social e estabelecer uma correlação empírica com indicadores de benefício.

Pode-se fazer uma relação, não exaustiva, das propriedades dos indicadores. Assim, estes devem (Grootaert, 1998):

- $\quad$ ser desenvolvidos de acordo com premissas conceituais e operacionais;

- ser definidos claramente e de fácil entendimento;

- permitir a agregação (por exemplo, de comunidade para estado, de estado para nação, etc.);

- ser objetivos (deve ser independente de quem coleta os dados);

- solicitar informações razoáveis, isto é, dados disponíveis ou dados que podem ser coletados a um custo limitado e dentro da capacidade de processamento estatístico do país; e,

- $\quad$ ser limitados em número.

Os indicadores de capital social diferem tanto geograficamente quanto setorialmente. Por exemplo, medidas de filiação a associações foi considerado um indicador relevante na Indonésia, Quênia, e em países da região andina. O mesmo não ocorreu para Índia e Rússia, onde relacionamentos informais são mais importantes. Assim, a escolha de proxy nos estudos de caso deve considerar as manifestações específicas de capital social na área de estudo, ou os veículos específicos (associações, redes de relacionamento, entre outros) pelo qual o capital social é adquirido. Em estudo $^{92}$ realizado por Gugerty \& Kremer, que avaliou o impacto de recursos de ONG na

\footnotetext{
${ }^{92}$ Citado em Grootaert \& van Bastelaer (2001).
} 
formação de capital social em grupos rurais de mulheres e em escolas primárias no Quênia, adotou-se medidas diferentes. Para o caso do grupo de mulheres, o capital social foi mensurado pela estrutura organizacional dos grupos, suas atividades de assistência mútua e a extensão de seus laços externos. No contexto das escolas, o capital social foi estimado pelo comparecimento dos pais nas reuniões, nível de cooperação entre professores e o número de visitas às escolas por agentes educacionais do governo. Ressalte-se que não há uma qualificação destas visitas, tanto de agentes educacionais quanto dos pais, o que limita o poder desta medida.

Concluindo este tópico, pode-se citar Dasgupta (2002, p.4): "The idea of social capital sits awkwardly in contemporary economic thinking. Even though it has a powerful, intuitive appeal, it has proven hard to track as an economic good. Among other things, it is fiendishly difficult to measure. This isn't because of a recognised paucity of data, but because we don't quite know what we should be measuring. Comprising different types of relationships and engagements, the components of social capital are many and varied and, in many instances, intangible ${ }^{93 " .}$

\subsection{Capital social e acesso ${ }^{94}$ ao crédito}

\section{"Unless new institutions find substitutes for the mechanisms used by the moneylenders to overcome the problems of screening, incentives and enforcement, the}

\footnotetext{
93 Tradução: a idéia de capital social acomoda-se desconfortavelmente no pensamento econômico contemporâneo. Embora tenha uma atração poderosa, intuitiva, provou ser de difícil enquadramento como um bem econômico. Entre outras coisas, é extremamente difícil para ser mensurado. Isto não se deve a reconhecida insuficiência de dados, mas porque nós não sabemos exatamente o que deveríamos estar medindo. Incluindo diferentes tipos de relações e compromissos, os componentes do capital social são muitos e variados e, em muitos casos, intangíveis.

94 Diagne \& Zeller (2001) corretamente afirmam que há uma confusão na definição de acesso ao crédito e participação em programas de crédito. Acesso ao crédito significa a possibilidade de tomar um empréstimo (limite de crédito), independentemente se a pessoa irá efetivamente tomar ou não os recursos (total ou parcialmente). Participação implica em já ter tomando empréstimo de uma fonte de recursos. Esta volume emprestado pode não ser o montante desejado (pode ocorrer restrição ao acesso).
} 
moneylenders' power is unlikely to be broken by the entry of institutional credit ${ }^{95 "}$

Stiglitz \& Weiss (1981)

Contratos financeiros representam uma troca de uma soma de dinheiro hoje com a promessa de retornar maior quantidade no futuro. Para que esta troca ocorra, o financiador deve considerar que a promessa é suficientemente crível. O principal fator que sustenta esta credibilidade é a possibilidade de executar (enforcing) o título nos tribunais. Mas esta não é a única fonte de credibilidade. A execução de um título é onerosa e muitas vezes ineficiente. Se o financiador teme que o financiado desapareça com o dinheiro, a proteção dada pelo contrato é muito limitada. Da mesma forma, restrições na possibilidade de infringir punição reduz a eficácia do contrato em prevenir o risco moral (Guiso et al., 2000). O financiado não é um agente passivo na resolução do empréstimo. Dois fatores opostos influenciam o financiado: penalidades (inclusive quanto a sua reputação) e custo de oportunidade. No caso de inadimplência, sua má reputação implicará em custos mais elevados em futuros empréstimos. Se este custo existe e é alto, ele buscará a adimplência. Caso contrário, tornar-se-á inadimplente (Lawrence \& Arshadi, 1995).

A utilização do capital social tem sido comum no mercado de crédito, tanto na estipulação de garantias (como no aval solidário ${ }^{96}$ ) quanto como alternativa de redução de custos para credores diante de informação imperfeita. Estas aplicações tem se

\footnotetext{
95 Tradução: A menos que novas instituições achem substitutos para os mecanismos usados pelos prestamistas (moneylenders) para superar os problemas de seleção, incentivos e execução, o poder dos prestamistas (moneylenders) dificilmente será quebrado pela entrada de crédito institucional.

${ }^{96} \mathrm{O}$ aval solidário ocorre quando um financiamento é feito a um membro de determinado grupo, sendo avalizado pelos demais membros. Assim, todos devem ajudar para que ocorra uma boa aplicação, sob pena de todo grupo ter que cobrir o saldo devedor de um dos seus membros (Bittencourt, 2001).
} 
voltado, em geral, para o acesso de pessoas mais pobres ao crédito ${ }^{97}$. Diferentes tipos de crédito com esta finalidade surgiram e podem ser classificados, como sugerido por van Bastelaer (2000), em quatro categorias: ROSCAs (Rotating Saving and Credit Associations); os prestamistas locais (local moneylenders); créditos comerciais; e, programas de microfinanças baseados em grupos.

A ROSCA é um grupo de pessoas que contribui para um fundo coletivo que em intervalos regulares é distribuído - aleatoriamente, por leilão, ou por decisão coletiva - para um dos membros do grupo. Após todos membros do grupo receberem sua parte, o grupo é desfeito, ou, o que é mais comum, inicia-se um novo grupo. Uma pessoa que após receber sua parte deixar de contribuir com o grupo, além de não participar de futuros grupos, em geral sofre sanções além do domínio da ROSCA. A comunidade exerce pressão (extensiva aos familiares do inadimplente) e ocorre isolamento social de elemento ${ }^{98}$.

Prestamistas locais refere-se a pessoas que emprestam a pessoas com as quais possuem uma longa relação e muita proximidade. É característico de familiares e amigos. Nestes casos, o credor possui ampla informação e alternativas para o repagamento, inclusive formas de pressão só possíveis face ao relacionamento estrito entre devedor e credor.

Crédito comercial é facilitado pelo relacionamento existente entre fornecedores e clientes. A reputação e o histórico do relacionamento são fundamentos para o acesso ao crédito comercial. Fafchamps \& Minten (1999) verificaram que os traders agrícolas em Madagascar valorizavam o capital social na medida que este

\footnotetext{
${ }^{97}$ Bialoskorski (2001) destaca que a capacidade de acesso aos fatores de produção (entre eles o crédito) é dada em proporção a intensidade de capital social. Da mesma forma, Guiso et al. (2000) observaram que áreas com maior capital social, na Itália, tem maior acesso a crédito. Karlan (2001) constatou que bancos ligados ao FINCA-Peru com mais capital social tem maiores repagamentos.

${ }^{98}$ Para maiores detalhes, vide:

BESLEY, T.; COATE, S.; LOURY, G. The economics of rotating savings and credit associations.
} American Economic Review, v.83, n.4, p.792-810. 1993. 
ampliava o acesso ao crédito informal e facilitava a execução contratual. Em Madagascar, segundo o mesmo estudo, apenas $4 \%$ dos traders obtinham crédito no mercado formal; e apenas 5\% haviam recorrido, em algum momento desde que iniciaram seus negócios, à polícia, advogados ou aos tribunais.

Os programas de microfinanças baseados em grupos tem sido a aplicação mais visível do capital social para o acesso ao crédito. Em geral caracterizam-se por grupos de mutuários de pequeno porte (que, em geral, não tem acesso aos bancos tradicionais $^{99}$ ) auto-selecionados, homogêneos (por exemplo, composto por pessoas de mesma atividade profissional), comuns em regiões densamente povoadas. $\mathrm{O}$ microcrédito adota sistemas de garantia mais próximos das condições sócio-econômicas dos pequenos empreendedores. A garantia apoia-se no capital social da comunidade: relações de confiança, reciprocidade e participação (Barone et al., 2002) .

Um exemplo de programa baseado em grupos é o caso do Sistema Cresol. Trata-se de um sistema de cooperativas de crédito rural com integração solidária, originada dos fundos rotativos, criados a partir de $1988^{100}$, para atender aos agricultores familiares e assentados do Paraná. A garantia de seus empréstimos é o aval solidário entre os tomadores de crédito. O microcrédito apresenta diversas técnicas, dentre as quais tem-se (Gasques \& Conceição, 2001):

a) empréstimos de valores unitários relativamente baixos, em geral de curto prazo;

b) incentivos aos cliente pontuais, como a possibilidade de tomar novos empréstimos $^{101}$;

\footnotetext{
99 Vide Gasques \& Conceição (2001) e Barone et al. (2002).

100 Experiências anteriores com microcrédito já existiam no Brasil, destacando-se a Cáritas Brasil, desde 1981, e a Rede Ceape, desde 1987 (Bittencourt, 2001), além do extinto Programa UNO (criado em 1973).

101 Entre as formas de incentivo, destacam-se os empréstimos progressivos, nos quais o primeiro empréstimo é de baixo valor e, conforme o tomador vai realizando pagamentos em dia, ele se elege para empréstimos de maior magnitude (Toneto Junior \& Gremaud, 2001).
} 
c) muitas vezes utilizam um processo de crédito que inclui a formação de um grupo e de um monitor como substituto da garantia convencional; e,

d) descentralização do mecanismo de empréstimo, onde o responsável pela concessão do empréstimo mantém um contato estreito com o cliente.

Diversas instituições financeiras foram criadas dedicadas ao microcrédito e algumas que já existiam incluíram esta modalidade de crédito entre suas atividades, cujas principais estão relacionadas na Tabela 10. Dentre estas, talvez a mais discutida seja o Grameen Bank, de Bangladesh. Seus empréstimos são garantidos por um esquema de fiança solidária, em que o empréstimo é concedido a um pequeno grupo de pessoas, sendo todos os membros do grupo responsáveis pela dívida. Inicialmente apenas dois membros recebem os empréstimos. Se estes honrarem seus compromissos, os demais membros do grupo também recebem empréstimos. Assim, ocorre um sistema de autoseleção e auto-monitoramento dentro do grupo (mecanismo de pressão dos pares), que tende a reduzir os problemas com risco moral e de seleção adversa, assim como os custos de gerenciamento do banco (Braga \& Toneto Junior, 2000).

Tabela 10. Principais instituições financeiras relacionadas ao microcrédito.

Região País Instituição

\begin{tabular}{|c|c|c|}
\hline \multirow[t]{3}{*}{ Ásia } & Indonésia & Banco Rakyat (BRI), criado em 1984 (14,5 milhões de clientes) \\
\hline & Tailândia & $\begin{array}{l}\text { Banco para Agricultura e Cooperativas Agrícolas (BAAC), } \\
\text { criado em } 1966 \text { (4,3 milhões de clientes) }\end{array}$ \\
\hline & Bangladesh & Grameen Bank (GB), criado em 1976 (2,1 milhões de clientes) \\
\hline \multicolumn{3}{|c|}{ América } \\
\hline \multirow[t]{2}{*}{ Latina } & Argentina & Banco da Nação Argentina (IFD com vocação multisetorial) \\
\hline & Brasil & Banco do Brasil (IFD com vocação multisetorial) \\
\hline
\end{tabular}


Tabela 10. Principais instituições financeiras relacionadas ao microcrédito.

\begin{tabular}{|c|c|c|}
\hline Região & País & Instituição \\
\hline & Costa Rica & Banco Nacional da Costa Rica (IFD com vocação multisetorial) \\
\hline & Chile & Banco do Estado do Chile (IFD com vocação multisetorial) \\
\hline & Peru & $\begin{array}{l}\text { Corporação Financeira de Desenvolvimento do Peru (IFD com } \\
\text { vocação multisetorial) }\end{array}$ \\
\hline & Bolívia & $\begin{array}{l}\text { Banco Solidariedade S.A. - BancoSol (IFD com vocação } \\
\text { multisetorial) }\end{array}$ \\
\hline & Equador & $\begin{array}{l}\text { Banco Nacional de Fomento (IFD com ações concentradas m } \\
\text { setor agropecuário) }\end{array}$ \\
\hline & Guatemala & $\begin{array}{l}\text { Banco Nacional de Desenvolvimento Agrícola (IFD com ações } \\
\text { concentradas no setor agropecuário) }\end{array}$ \\
\hline & Honduras & $\begin{array}{l}\text { Banco Nacional de Desenvolvimento Agrícola (IFD com ações } \\
\text { concentradas no setor agropecuário) }\end{array}$ \\
\hline & Panamá & $\begin{array}{l}\text { Banco de Desenvolvimento Agropecuário (IFD com ações } \\
\text { concentradas no setor agropecuário) }\end{array}$ \\
\hline & Paraguai & $\begin{array}{l}\text { Banco Nacional de Fomento (IFD com ações concentradas no } \\
\text { setor agropecuário) }\end{array}$ \\
\hline & $\begin{array}{l}\text { República } \\
\text { Dominicana }\end{array}$ & $\begin{array}{l}\text { Banco Agrícola (IFD com ações concentradas no setor } \\
\text { agropecuário) }\end{array}$ \\
\hline
\end{tabular}


Tabela 10. Principais instituições financeiras relacionadas ao microcrédito.

\begin{tabular}{|c|c|c|}
\hline Região & País & Instituição \\
\hline & Colômbia & $\begin{array}{l}\text { Sistema Nacional de Crédito Agropecuário, constituído por } \\
\text { Caixa Agrária, Banco do Café, Banco do Gado, Fundos de } \\
\text { Gado e Entidades Financeiras Privadas, que se utilizam de } \\
\text { recursos próprios e de redesconto proveniente do Fundo } \\
\text { para Financiamento do Setor Agropecuário (FINAGRO) e } \\
\text { do Banco Colombiano de Comércio Exterior } \\
\text { (BANCOLDEX) }\end{array}$ \\
\hline & México & Banco Nacional de Crédito Rural (BANRURAL) \\
\hline & México & $\begin{array}{l}\text { Fideicomissos Instituídos em Relação à Agricultura (FIRA) do } \\
\text { Banco do México }\end{array}$ \\
\hline & Brasil & BNDES, através do Programa de Crédito Produtivo Popular \\
\hline & Brasil & Banco do Nordeste (Programa CrediAmigo) \\
\hline
\end{tabular}

Fonte: Gasques \& Conceição (2001), Barone et al. (2002) e Meyer \& Nagarajan (2000)

Nota: IFD = Instituições Financeiras de Desenvolvimento.

Outro modelo de empréstimo em grupo é a concessão de financiamento a todos os membros do grupo, mas, se um indivíduo falhar, o resto do grupo assume seu débito (Toneto Junior \& Gremaud, 2001). Esta é a forma utilizada, entre outros, pelo Banco Solidário (Banco Sol), da Bolívia. 
No Brasil, embora tenha sido um dos pioneiros ${ }^{102}$ em experiências com microcrédito, a indústria de microfinanças desenvolveu-se efetivamente somente após 1994, com a estabilização macroeconômica. Até aquela data, operavam apenas a Rede CEAPE (Centro de Apoio aos Pequenos Empreendimentos), originada em 1987; e, o Banco da Mulher, criado em 1989. Estes dois programas de microcrédito utilizavam a metodologia de grupos solidários. Em 1996, o BNDES passou a apoiar o fortalecimento das organizações de microcrédito através do Programa de Crédito Produtivo Popular. A partir de 1998, o Banco do Nordeste passou a atuar diretamente com 50 agências especializadas do Programa CrediAmigo. Atualmente existem, no Brasil, 24 sociedades de crédito ao microempreendedor (SCM) e 67 organizações não-governamentais (ONGs) microfinanceiras qualificadas como organizações da sociedade civil de interesse público (OSCIPs). Além dos já citados Rede CEAPE e Banco da Mulher, destacam-se a Portosol (criada em 1995), o VivaCred (criado em 1996), o CrediAmigo (criado em 1998), o Programa SEBRAE de Microcrédito (criado em 2001), a Caixa Econômica Federal e diversas experiências estaduais e municipais, como os diversos Banco do Povo (Barone et al., 2002).

\footnotetext{
102 Em 1973, nos municípios de Recife e Salvador, foi criada a União Nordestina de Assistência a Pequenas Organizações - Programa UNO. Apesar de ter sido uma das principais referências para expansão do microcrédito na América Latina, o Programa UNO não apresentou auto-sustentabilidade, tendo desaparecido após dezoito anos de atuação (Barone et al., 2002). As diversas formas de consórcios informais, populares nas décadas de 70 e 80, reforçam a posição pioneira do Brasil com experiências de microcédito.
} 


\section{CONFIABILIDADE E A OFERTA DE CRÉDITO RURAL}

\subsection{Confiabilidade}

As informações necessárias aos tomadores de decisão de crédito podem ser divididas em dois grupos: pessoais e complementares. As informações pessoais, como a reputação, são aquelas que afetam e são afetadas pelo capital social. As informações complementares referem-se aos capitais natural e físico. Nesta seção, as referências ao conceito informação estão ligadas ao grupo de dados pessoais.

A informação e o capital social afetam o volume de negócios de forma substitutiva ${ }^{103}$. Coeteris paribus, quanto mais informação e/ou maior for o capital social, maior será o volume de negócios. Pode-se considerar que a soma de informações com capital social resulte em um vetor, que será denominado confiabilidade. Quanto mais alta for a confiança dos ofertantes de recursos na seleção, no monitoramento e na execução de seus créditos, maior volume de recursos será ofertado, aceitando menores taxas remuneratórias (menor será o risco). Assim:

\footnotetext{
${ }^{103}$ Ou seja, quando há pouca informação sobre determinado risco de crédito, um elevado capital social pode proporcionar maior segurança na concessão de um empréstimo. Por outro lado, se há grande quantidade (e qualidade) de informação disponível, não há necessidade de capital social para que o agente se sinta confortável para conceder um empréstimo.
} 


$$
V C^{S}=f(j, c)
$$

em que:

$$
\begin{aligned}
& V C^{S}=\text { volume ofertado de crédito } \\
& j=\text { taxa de juros } \\
& c=\text { confiabilidade (informação + capital social) }
\end{aligned}
$$

Sendo que:

$$
\frac{\partial V C^{S}}{\partial c}>0
$$

A Figura 27 representa esta relação hipotética:

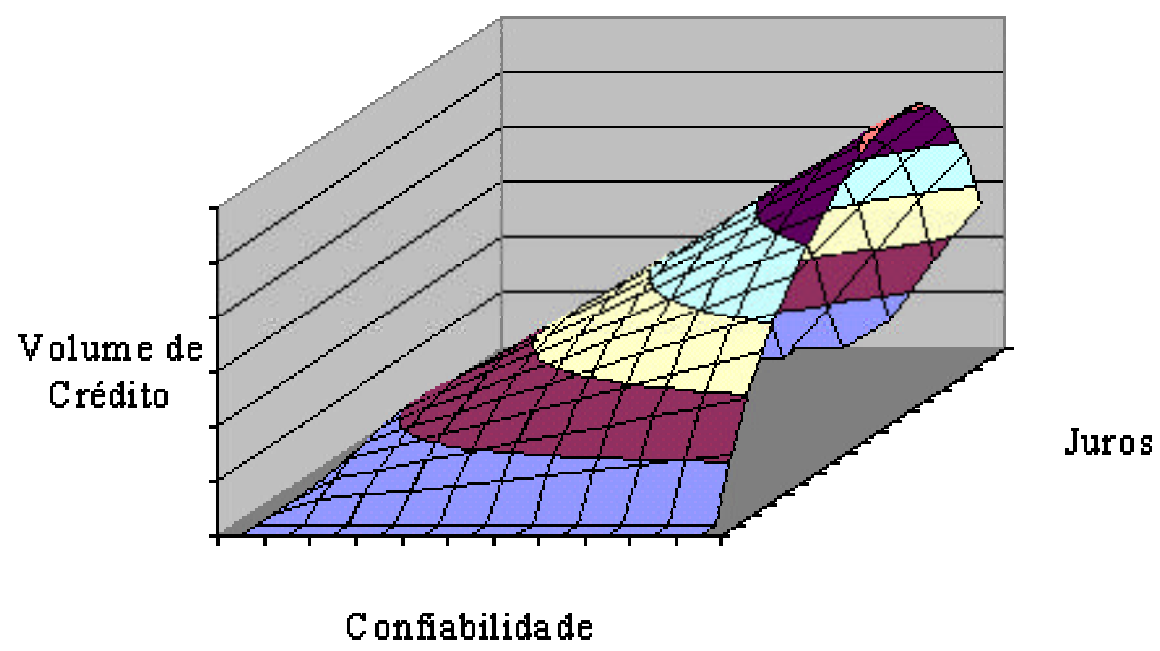

Figura 27 - Relação hipotética ente taxa de juros, confiabilidade e o volume de crédito ofertado. 
A relação entre informação e capital social é mais complexa do que a simples soma na formação da confiabilidade. Há uma sinergia entre estes conceitos. Capital social possui uma dimensão de informação. Uma de suas características é a capacidade de gerar informações, em especial sobre a coletividade. A reputação originada em determinado grupo de relações sociais é uma informação relevante no mercado de crédito. Da mesma forma, informações individuais também são geradas. A auto-seleção, característica de grupos com maior capital social, pode evitar a seleção inadequada de um potencial mau pagador. Por outro lado, o conjunto de informações sobre os indivíduos proporciona condição para que ocorra formação de capital social.

\subsection{Volume de crédito rural}

Considerando a Figura 20, a oferta de crédito pode ser representada conforme ilustrado na Figura 28.a. No Brasil, a taxa de crédito rural é fixada em nível inferior ao praticado em outras operações do mercado financeiro. Da mesma forma, o limite legal ${ }^{104}$ para operações entre empresas não financeiras (por exemplo, indústria de defensivos) e produtores rurais também é inferior às taxas praticadas em outras operações do mercado financeiro. Desta forma, pode-se considerar como relevante para as operações de crédito rural apenas o trecho de inclinação positiva da curva de oferta (Figura 28.b).

${ }^{104}$ Limite de $12 \%$ ao ano, estabelecido pelo Decreto ${ }^{\circ} 22.629$, de 07.04.33 — Lei da Usura. 


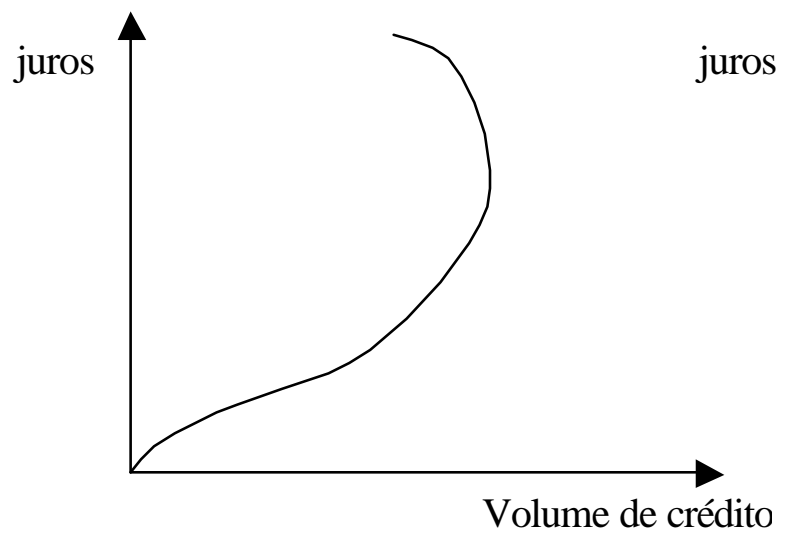

(a)

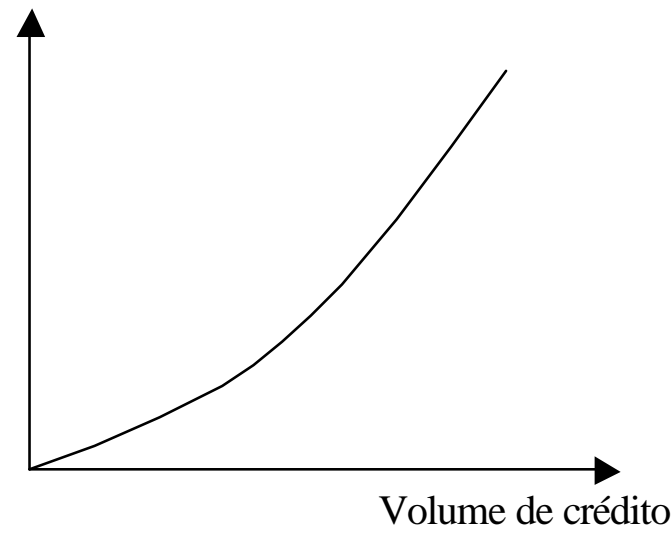

(b)

Figura 28 - Curva de oferta de crédito.

A curva de demanda por crédito, em uma situação de mercado livre, seria negativamente inclinada (Figura 29.a). No entanto, face à limitação dos juros em um patamar máximo, a curva de demanda apresentará um segmento infinitamente elástico (Figura 29.b), em que r* é o limite legal de juros. 


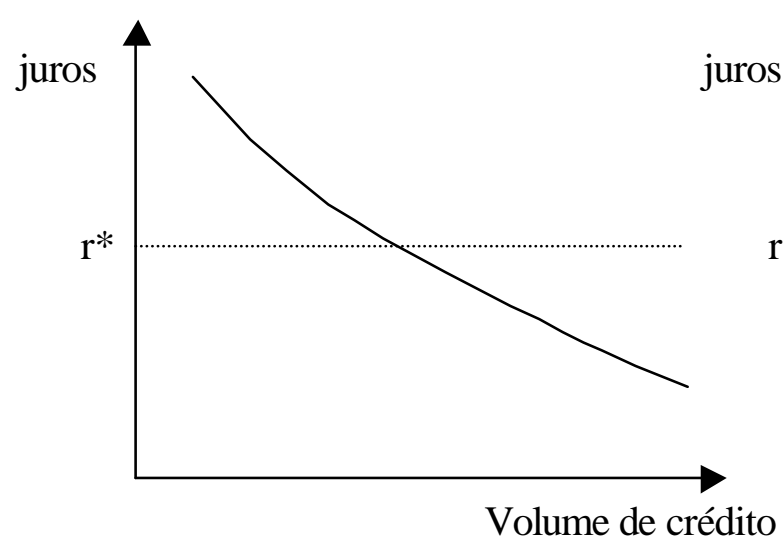

(a)

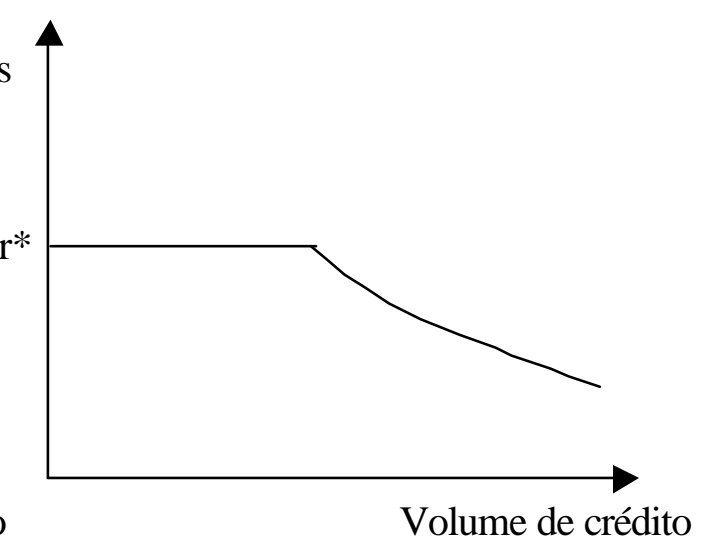

(b)

Figura 29 - Curva de demanda de crédito.

Assim, o mercado de crédito rural pode ser representado conforme Figura 30. A presença de custos de transação implica que demandantes e ofertantes de crédito observarão taxas de juros diferentes. $\mathrm{O}$ tomador de crédito (demandante) fará sua escolha baseado na taxa de juros do financiamento ( $\left.\mathrm{r}^{*}\right)$. O credor (ofertante) fará sua escolha considerando a taxa de retorno do crédito (r'), isto é, a taxa de juros paga pelo tomador líquida dos custos de transação.

Nesta situação, o equilíbrio de mercado ocorrerá no ponto $\boldsymbol{E}$, onde o volume de operações de crédito será q'. A esta mesma taxa de juros, a demanda total é de q". Assim, há um racionamento de crédito no montante de (q" - q').

Uma elevação na confiabilidade (informação + capital social) deslocaria o equilíbrio de mercado até o ponto $\boldsymbol{F}$, resultando em uma elevação no volume de crédito (Figura 31), de q' para $\mathrm{q}^{\mathrm{c}}$, reduzindo o racionamento. A elevação na confiabilidade também reduz o custo de transação. 


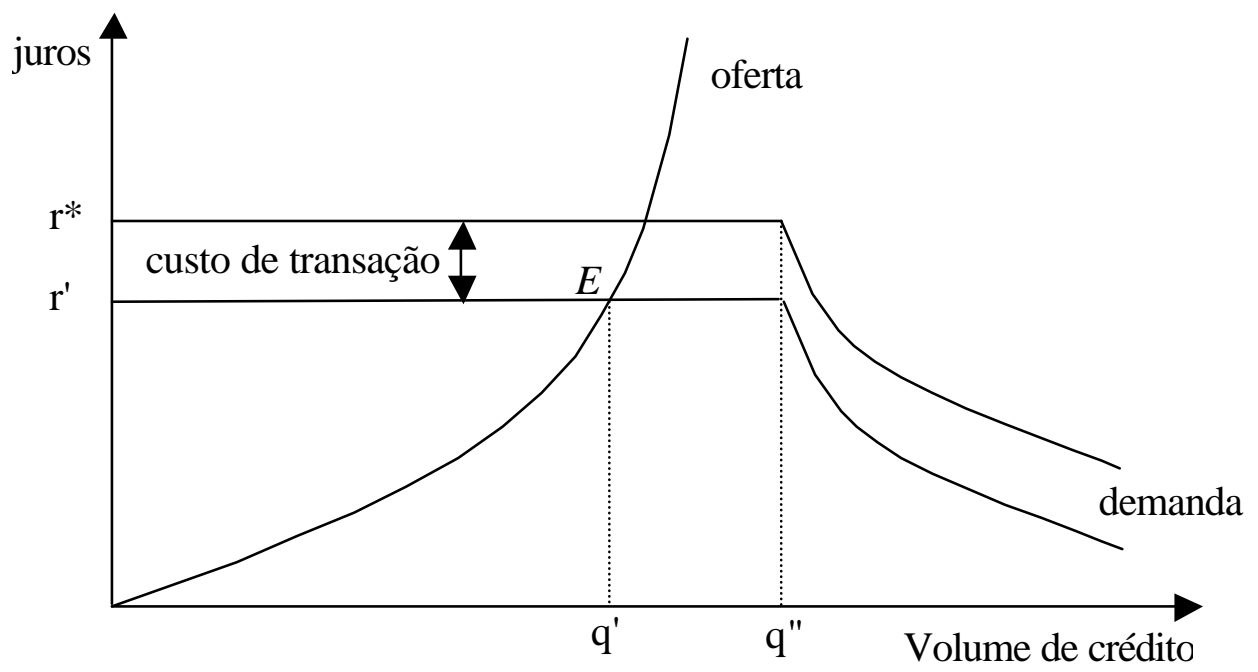

Figura 30 - Mercado de crédito rural.

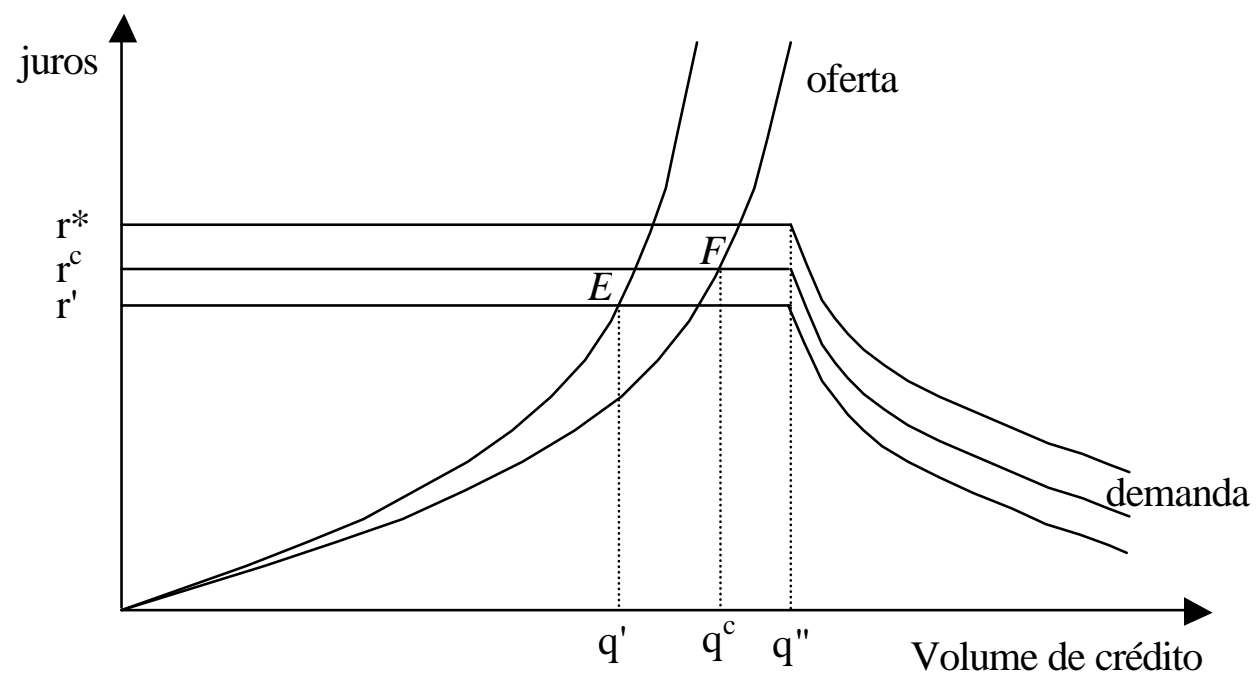

Figura 31 - Mercado de crédito rural com elevação da confiabilidade. 